\title{
Evaporite karst in Italy: a review
}

Jo De Waele ${ }^{*}$, Leonardo Piccini², Andrea Columbu ${ }^{3}$, Giuliana Madonia ${ }^{4}$, Marco Vattano $^{4}$, Chiara Calligaris ${ }^{5}$, Ilenia M. D’Angeli ${ }^{1}$, Mario Parise ${ }^{6}$, Mauro Chiesi ${ }^{7}$, Michele Sivelli ${ }^{7}$, Bartolomeo Vigna ${ }^{8}$, Luca Zini ${ }^{5}$, Veronica Chiarini ${ }^{1,9}$, Francesco Sauro ${ }^{1}$, Russell Drysdale ${ }^{3}$, and Paolo Forti ${ }^{1}$

\footnotetext{
${ }^{1}$ Department of Biological, Geological and Environmental Sciences, University of Bologna, Via Zamboni 67, 40126 Bologna, Italy

${ }^{2}$ Department of Earth Sciences, University of Florence, Via La Pira 4, 50121 Firenze, Italy

${ }^{3}$ School of Geography, University of Melbourne, VIC 3010, Australia

${ }^{4}$ Department of Earth and Marine Sciences, University of Palermo, Via Archirafi 22, 90123 Palermo, Italy

${ }^{5}$ Department of Mathematics and Geosciences, Trieste University, Via Weiss 2, 34127 Trieste, Italy

${ }^{6}$ Department of Earth and Geo-Environmental Sciences, Università "Aldo Moro", Bari, Italy

${ }^{7}$ Società Speleologica Italiana, Via Zamboni 67, 40126 Bologna, Italy

${ }^{8}$ Department of Territorial Engineering, of the Environment and of Geotechnologies, Politechnical University of Turin,

Corso Duca degli Abruzzi 24, 10129 Torino, Italy

${ }^{9}$ Laboratoire EDYTEM, UMR CNRS 5204, Université Savoie Mont Blanc, Pôle Montagne, 73376 Le Bourget du Lac cedex, France
}

\begin{abstract}
Although outcropping rarely in Italy, evaporite (gypsum and anhydrite) karst has been described in detail since the early $20^{\text {th }}$ century. Gypsum caves are now known from almost all Italian regions, but are mainly localised along the northern border of the Apennine chain (Emilia Romagna and Marche), Calabria, and Sicily, where the major outcrops occur. Recently, important caves have also been discovered in the underground gypsum mines in Piedmont. During the late 80 s and 90 s several multidisciplinary studies were carried out in many gypsum areas, resulting in a comprehensive overview, promoting further research in these special karst regions. More recent and detailed studies focused on the gypsum areas of Emilia-Romagna and Sicily. Sinkholes related to Permian-Triassic gypsum have been studied in Friuli Venezia Giulia. This article reviews the state of the art regarding different aspects of evaporite karst in Italy focusing on the main new results.
\end{abstract}

Keywords: $\quad$ gypsum karst, Italy, geology, geomorphology, palaeoclimate, hazards, sinkholes

Received 12 December 2016; Revised 16 February 2017; Accepted 22 February 2017

Citation: De Waele J., Piccini L., Columbu A., Madonia G., Vattano M., Calligaris C., D'Angeli I.M., Parise M., Chiesi M., Sivelli M., Vigna B., Zini L., Chiarini V., Sauro F., Drysdale R. and Forti P., 2017. Evaporite karst in Italy: a review. International Journal of Speleology, 46 (2), 137-168. Tampa, FL (USA) ISSN 0392-6672 https://doi.org/10.5038/1827-806X.46.2.2107

\section{INTRODUCTION}

Gypsum crops out in almost all Italian regions, representing less than $1 \%$ of the total national territory (Fig. 1). Since most of these evaporite outcrops are very small and host only caves of limited development, more or less detailed studies on gypsum karst have been carried out in only four regions: Piedmont, Emilia-Romagna (Klimchouk et al., 1996), Calabria, and Sicily. Gypsum is of Permo-Triassic and Messinian age, while anhydrites belong to some Triassic sequences (Cucchi \& Piano, 2003).

Researches on these evaporite karst areas in Italy started very early, probably in the $16^{\text {th }}$ century. From a cave near Bologna curious speleothems, called "stelechiti", were described and drawn by Aldrovandi (1648) in the "Musaeum metallicum" (Fig. 2A) (Table 1). From the same region (Emilia-Romagna) several authors, such as Cosimo Bottegari (1612), Luigi Ferdinando Marsili (1698) (Fig. 2C), Antonio Vallisneri (1715), Lazzaro Spallanzani (1762) and Serafino Calindri (1781) described respectively the Poiano Springs (Upper Secchia Valley), the petrography of gypsum, the gypsum area in the Upper Secchia Valley (Reggio Emilia) and surface karst landforms from areas close to Bologna (Altara et al., 1995), while another geologist, Tommaso Laghi (1803), published a description of the cave mineral epsomite, found in a gypsum cave near Bologna. Another old description of gypsum karst landscape was given by the famous Swiss naturalist and mountaineer De Saussure in "Voyages dans les Alpes", where he described the geomorphological phenomena of the Moncenisio area (De Saussure, 1796). Capellini (1876) described and drew the famous gypsum candles near Bologna, giving a first scientific explanation for their formation 


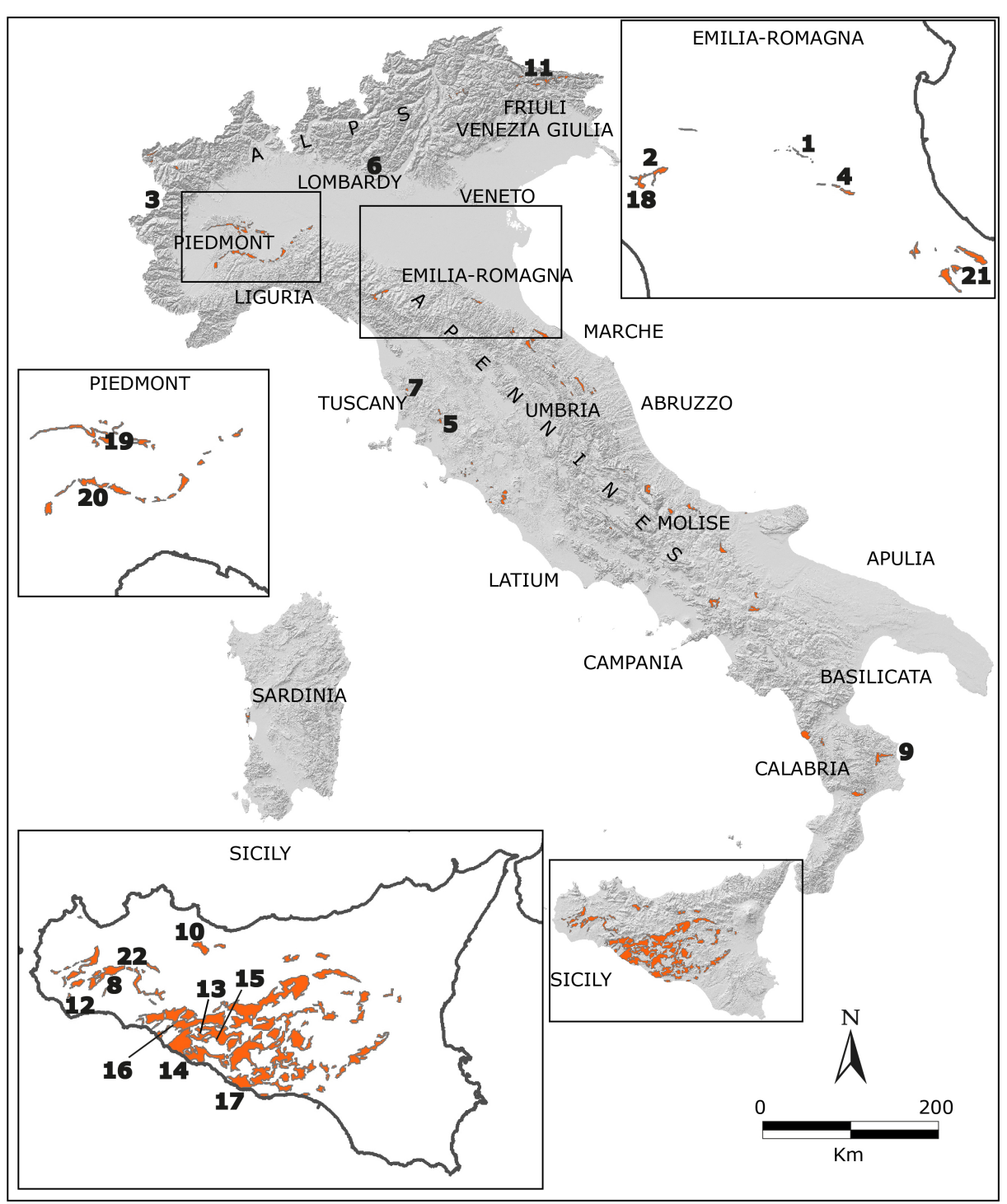

Fig. 1. Distribution of the main gypsum outcrops in Italy. 1) Acquafredda-Spipola Cave (Bologna); 2) Poiano (Upper Secchia Valley); 3) Moncenisio area; 4) Re Tiberio-Rio Basino (Vena del Gesso);

5) Grotta delle Vene (Grosseto); 6) Esino (Brescia); 7) Montecatini (Pisa); 8) Santa Ninfa (Trapani);

9) Grave Grubbo, Verzino (Crotone); 10) Ciminna (Palermo); 11) Quinis (Udine); 12) Preola

Lake-Gorghi tondi (Trapani); 13) Sant'Angelo Muxaro (Agrigento); 14) Siculiana (Agrigento); 15)

Monte Conca (Caltanissetta); 16) Montallegro (Agrigento); 17) Palma di Montechiaro (Agrigento);

18) Sassalbo (Massa-Carrara); 19) Moncalvo-Calliano (Asti); 20) Monticello d'Alba (Cuneo); 21)

Onferno (Rimini); 22) Rocca di Entella (Palermo).

(Fig. 2B), and Scarabelli described the Re Tiberio cave in the Vena del Gesso Romagnola, publishing the first topography of a gypsum cave in Italy (Scarabelli, 1872) (Fig. 3). Until the $19^{\text {th }}$ century there are less reports on gypsum karst phenomena in the other Italian regions (Sivelli, 2003). The only ones worth citing are those by Volta (1786) and Cozzaglio (1893) regarding evaporite areas in Lombardy, and the works by Gemmellaro (1850) and Baldacci (1886) on the extensive Sicilian karst (Fig. 2D). It is in the early $20^{\text {th }}$ century that researches on evaporite karst intensify, mainly in Sicily (Marinelli, 1899, 1910, 1911; Gemmellaro, 1915, see also Madonia et al., 2016), with the first monographic and comprehensive overview on the karst phenomena in Italian gypsum areas being published in 1917 (Marinelli, 1917). After this fundamental work, however, studies on this special kind of karst languished for over 50 years in most regions (also considering the occurrence of World conflicts), excluding the description of karst phenomena and some caves in
Romagna (Mornig, 1935) and the first real systematic multidisciplinary study on a gypsum karst area in Italy, in the Upper Secchia Valley, Reggio Emilia (AA. VV., 1949).

It is however always near to Bologna that scientific research continued in the late $60 \mathrm{~s}$ and early $70 \mathrm{~s}$, especially with the works on paragenesis and ceiling channels in the gypsum caves by Pasini (1967a, b, 1975 ) and the description of Pleistocene fauna from a palaeo-sinkhole (Pasini, 1969, 1970). Also the role of $\mathrm{CO}_{2}$ in the dissolution mechanisms of gypsum and the deposition of carbonate speleothems in these caves is based on observations in this area (Forti \& Rabbi, 1981), as is the importance of condensation waters (Cigna \& Forti, 1986). Furthermore, the possibility to use the deviation of speleothems' growth axes as indicators of past earthquakes, first detected in speleothems from Frasassi cave (in limestone, Marche), were also studied in a stalagmite of a gypsum cave (Buco dei Buoi) near Bologna (Forti \& Postpischl, 1980). 


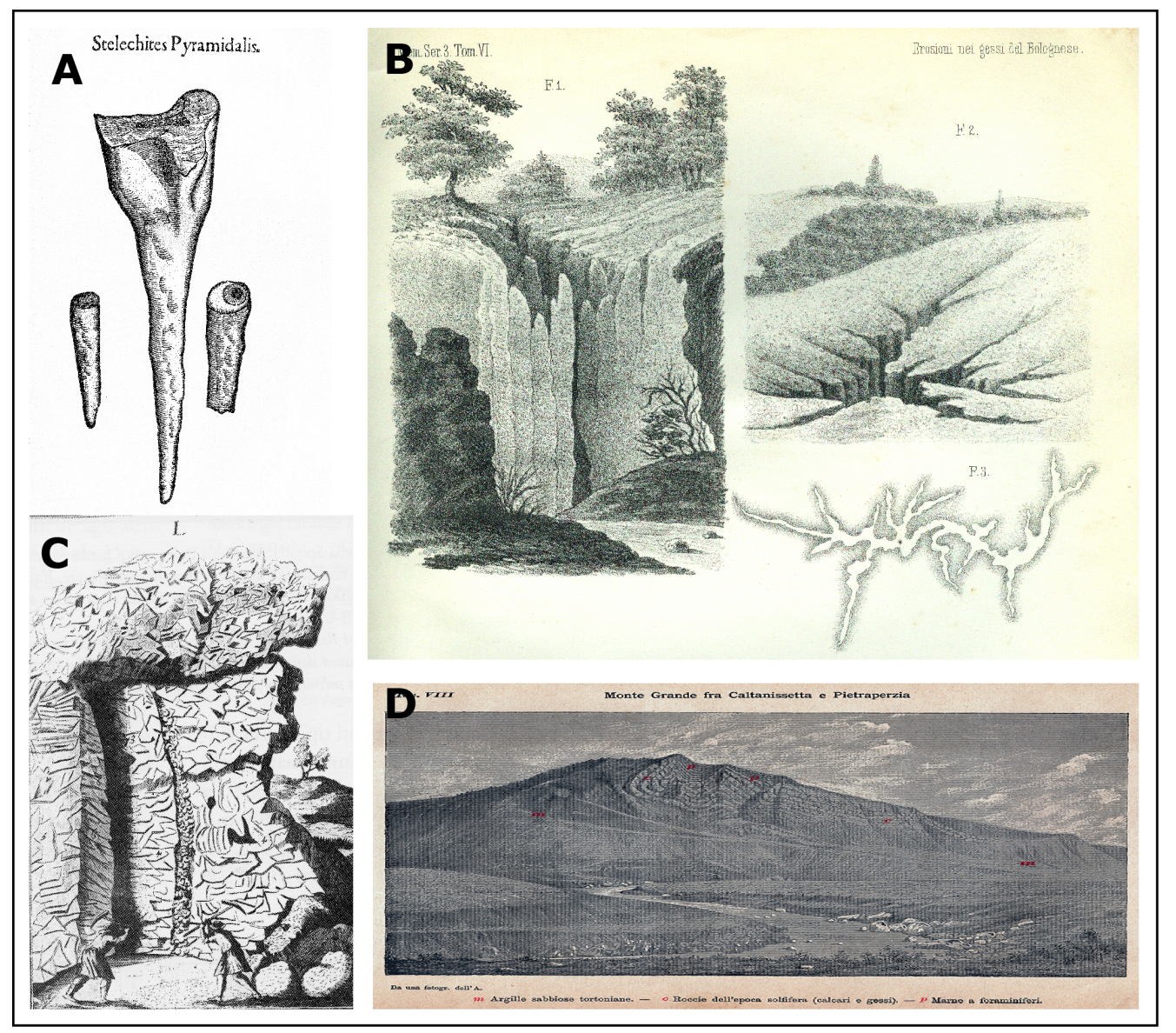

Fig. 2. Historical figures on gypsum karst in Italy. A) The Stelechites from Aldrovandi (1648);

B) The Candles and the close by Buco del Belvedere sinkhole (Bologna) drawn by Capellini (1876);

C) Gypsum quarry near Bologna by Marsili (1698); D) A geological drawing on Sicilian gypsum karst by Baldacci (1886).

Table 1. Historical overview on studies carried out in Italian gypsum areas before 1917, year in which Marinelli's review was published.

\begin{tabular}{|c|c|c|c|c|}
\hline Year & Author & Subject & Area & Region \\
\hline 1612 & Cosimo Bottegari & Poiano springs & Reggio Emilia & Emilia-Romagna \\
\hline 1648 & Ulisse Aldrovandi & Speleothems "stelechiti" & Bologna & Emilia-Romagna \\
\hline [1698-1700 ca] & Luigi Ferdinando Marsili & Mining and property of gypsum & Bologna & Emilia-Romagna \\
\hline 1715 & Antonio Vallisneri & $\begin{array}{l}\text { Hydrogeological researches, } \\
\text { Triassic, Valestra Cave }\end{array}$ & Reggio Emilia & Emilia-Romagna \\
\hline 1762 & Lazzaro Spallanzani & Hydrogeological researches & Reggio Emilia & Emilia-Romagna \\
\hline [1756-1762 ca] & Tommaso Laghi & Property of gypsum & Bologna & Emilia-Romagna \\
\hline 1781 & Serafino Calindri & $\begin{array}{l}\text { Karst landform description, } \\
\text { Acquafredda sinking stream }\end{array}$ & Bologna & Emilia-Romagna \\
\hline 1788 & Giovanni Serafino Volta & Camarà Cave description & Pavia & Lombardy \\
\hline 1796 & Horace-Bénedict De Saussure & $\begin{array}{l}\text { Description of the karst landscape } \\
\text { of Moncenisio }\end{array}$ & Torino & Piedmont \\
\hline 1872 & Giuseppe Scarabelli & $\begin{array}{l}\text { Description (1856) of Re Tiberio } \\
\text { Cave, first cave survey in gypsum }\end{array}$ & Faenza & Emilia-Romagna \\
\hline 1876 & Giovanni Capellini & $\begin{array}{l}\text { Karst landscape, caves Buco del } \\
\text { Belvedere, Buco delle Candele }\end{array}$ & Bologna & Emilia-Romagna \\
\hline 1886 & Luigi Baldacci & Mining and geological description & & Sicily \\
\hline 1890 & Raffaele Vittorio Matteucci & $\begin{array}{l}\text { Cave description of Grotta } \\
\text { delle Vene }\end{array}$ & Grosseto & Tuscany \\
\hline 1893 & Arturo Cozzaglio & Description of the Esino doline & Brescia & Lombardy \\
\hline 1907 & Giuseppe Stefanini & Karst in Val d'Era & Pisa & Tuscany \\
\hline 1915 & Mariano Gemmellaro & $\begin{array}{l}\text { Gypsum karst landscape, } \\
\text { Santa Ninfa Cave }\end{array}$ & Trapani & Sicily \\
\hline 1917 & Olinto Marinelli & Italian gypsum areas & & Italy \\
\hline
\end{tabular}




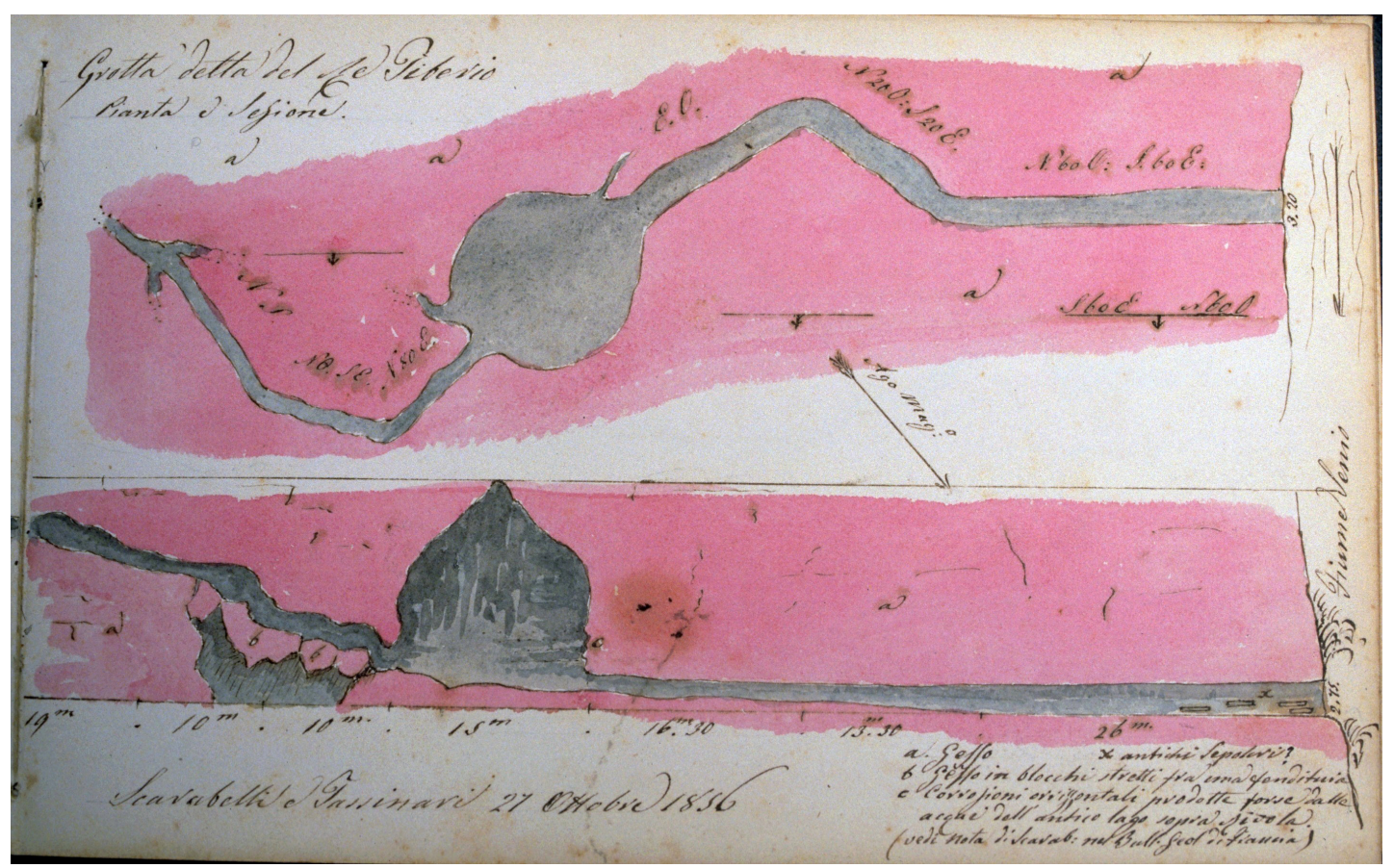

Fig. 3. The first survey of a gypsum cave in Italy: the Re Tiberio entrance area near Riolo Terme (Vena del Gesso) drawn by Scarabelli in 1872

The birth of caving associations in the 80s caused an exponential increase in the exploration and study of the gypsum areas, mainly in Emilia-Romagna (Casali, 1972; Colalongo et al., 1985; Forti et al., 1985, 1989; AA.VV., 1988; Forti \& Francavilla, 1990; Bentini \& Lucci, 1999; Chiesi, 2001; Dalmonte et al., 2004; Forti \& Lucci, 2010; Demaria et al., 2012; Pasini, 2012; De Waele \& Pasini, 2013; Ercolani et al., 2013; Columbu et al., 2015; Lucci \& Piastra, 2015), but also in Sicily (Agnesi et al., 1986; Agnesi \& Macaluso, 1989; Macaluso et al., 2001; Ferrarese et al., 2002; Liguori et al., 2008; Vattano, 2008; Madonia \& Sauro, 2009; Madonia \& Vattano, 2011; Di Maggio et al., 2012, 2016a, b; Vattano et al., 2015) and Calabria (Ferrini, 1998; Parise \& Trocino, 2005). Thanks to these studies, several international conferences on evaporite karst have been organised in Italy (Forti \& Grimandi, 1986; Forti et al., 1987; Forti, 2004). This paper intends to present a review on the most recent knowledge on gypsum karst in Italy.

\section{GEOLOGY}

Gypsum deposits are usually formed in shallow marine basins under arid to semi-arid climatic conditions and with a very low feeding of terrigenous siliciclastic sediments from continental areas. In the Alpine and Apennine sedimentary sequences these conditions occurred only during the Permian-Triassic in the Tethys basin (Stampfli et al., 2001), and in the Mediterranean basin during the Messinian Salinity Crisis (Hsü et al., 1977; Roveri et al., 2001) (Fig. 4).

Permian-Triassic gypsum deposits are associated with peri-continental evaporite deposition, which also includes halite and dolomite deposits, whereas Messinian gypsum layers are interlayered with shaly sequences of marine environments. Presently, the
Permian-Triassic evaporites crop out mainly in the Eastern Alps and in the Northern Apennines, whereas Messinian gypsum crops out in the whole Apennine chain and mainly in Sicily (Fig. 1). A general overview of the geological formations containing evaporite beds is shown in Table 2.

\section{Permian gypsum}

The most ancient gypsum deposits in Italy occur in the eastern Southern Alps (Dolomites and Carnic Alps) and consist of discontinuous layers of gypsum belonging to the basal succession of the Bellerophon Formation (Upper Permian). Evaporites were deposited because of periodical transgressions that affected the southern limit of Eurasia. Gypsum is irregularly spread due to the unequal morphology of the peri-continental platform, which was periodically flooded during marine high-stands. The Bellerophon Formation is characterised by different facies and thickness related to its position within the basin. Total thickness ranges from 0 to about $600 \mathrm{~m}$ going eastward from the western Adige Valley area to the Carnia depocenter (Cirilli et al., 1998). Three main lithofacies are generally present. Millimetre to centimetre layers of saccharoid gypsum prevails in the lower part, interlayered with mudstones and shales and, going upward, with dolostone. Dolomites and dolomitic breccias prevail in the middle lithofacies. The upper part of this formation consists of usually dark fossiliferous limestones that are thinner or absent in the western and southwestern Dolomites. The basal evaporitic facies has the maximum thickness in the Badia Valley to the east (about $350 \mathrm{~m}$ ) and becomes thinner towards the basin margin to the west.

In the eastern Southern Alps this formation is intensively deformed due to alpine tectogenesis, when evaporitic horizons acted as detachment surfaces of the upper limestone and sandstone of the Werfen Formation. 

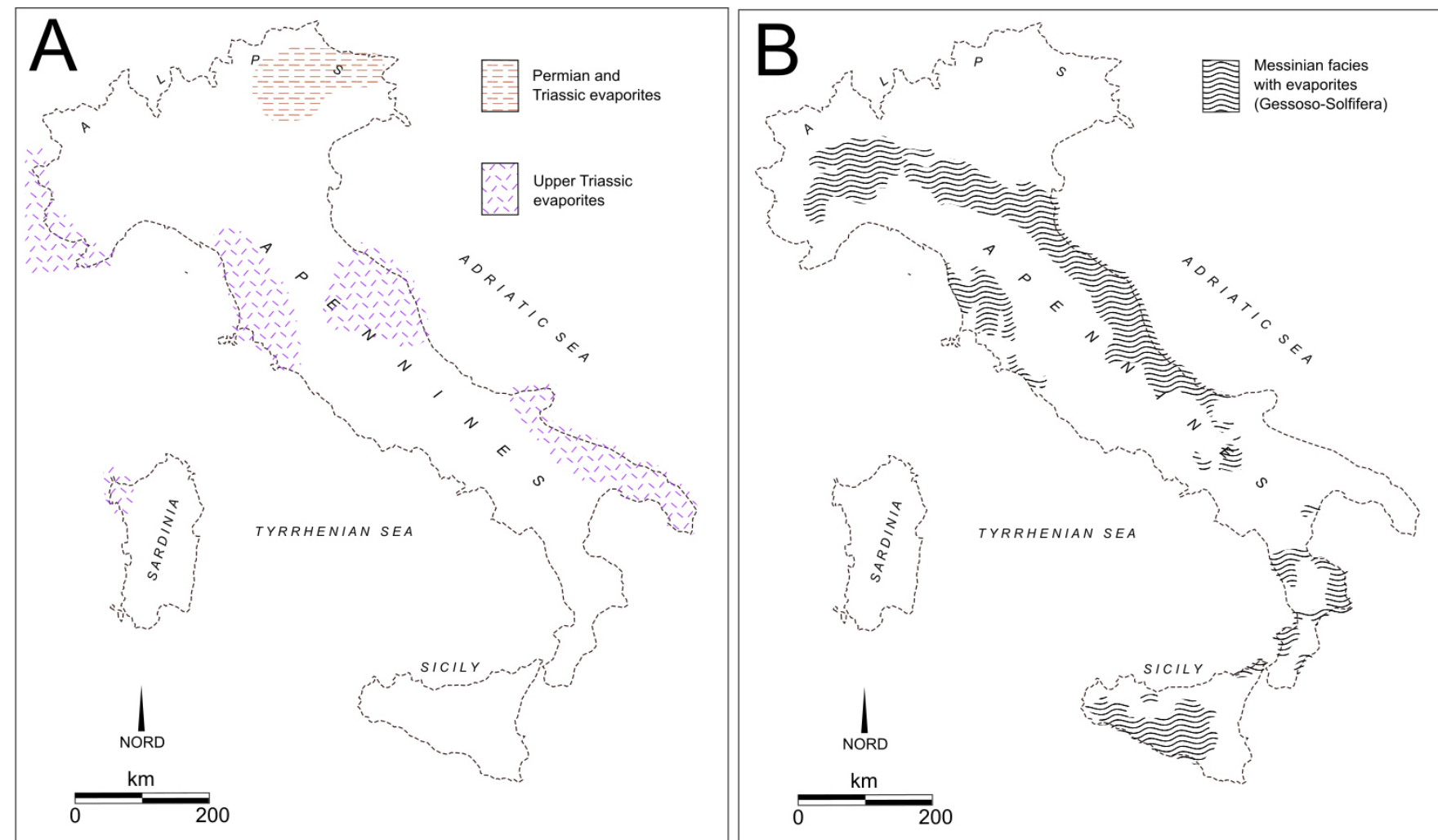

Fig. 4. Palaeogeographic schemes of gypsum deposition during the Permo-Triassic (A) and the Messinian (B).

Table 2. Main evaporite formations in Italy.

\begin{tabular}{|c|c|c|c|}
\hline Name & Age & Paleogeographic domain & Regions with major present outcrops \\
\hline Bellerophon Fm. & $\begin{array}{l}\text { Upper } \\
\text { Permian }\end{array}$ & $\begin{array}{c}\text { "Sudalpino" } \\
\text { (east-southern Alps) }\end{array}$ & Veneto, Friuli Venezia Giulia \\
\hline Werfen Fm. & Lower Triassic & $\begin{array}{c}\text { "Sudalpino" } \\
\text { (east-southern Alps) }\end{array}$ & Veneto \\
\hline “Gracilis" Fm. & Anisian & $\begin{array}{c}\text { "Sudalpino" } \\
\text { (east-southern Alps) }\end{array}$ & Lombardy \\
\hline Bovegno Fm. & Anisian & $\begin{array}{c}\text { "Sudalpino" } \\
\text { (east-southern Alps) }\end{array}$ & Lombardy \\
\hline Raibl Fm. & Carnian & $\begin{array}{c}\text { "Sudalpino" } \\
\text { (east-southern Alps) }\end{array}$ & Veneto, Friuli Venezia Giulia \\
\hline “Keuper” Fm. & Norian & $\begin{array}{l}\text { Delfinese-Provenzale } \\
\text { (western Alps) }\end{array}$ & Piedmont, Liguria, Sardinia \\
\hline Anidriti di Burano Fm. & Norian-Rhaetian & $\begin{array}{c}\text { Apennines, } \\
\text { Apulian platform }\end{array}$ & $\begin{array}{c}\text { Emilia-Romagna, Tuscany, Umbria, Marche, } \\
\text { Abruzzo, Apulia }\end{array}$ \\
\hline Gessoso-Solfifera Fm. & Messinian & Western Mediterranean & $\begin{array}{c}\text { Piedmont, Emilia Romagna, Tuscany, Umbria, } \\
\text { Marche, Campania, Calabria, Sicily }\end{array}$ \\
\hline
\end{tabular}

\section{Lower-Middle Triassic}

During early Triassic in the "alpine" sector of the Tethys, arid and subtropical climatic conditions favoured the formation of evaporites only in restricted areas. Gypsum lenses occur in the Werfen Formation (Schytian) in the Dolomites area (Cucchi \& Piano, 2003). More extensive and thick evaporite bodies were deposited mainly in the Lombardy and Venetian preAlps where wide horizons of gypsum, whose facies can be related to sabkha conditions, occur in the Bovegno Formation, which mainly consists of wellstratified dolomitic limestone and carbonate breccias. Climatic and palaeo-geographic conditions suitable for evaporitic deposition also occurred during Middle Triassic but this phase affected the alpine sector marginally, where a significant gypsum layer is only found in the "Gracilis" Formation. Some lenses of gypsum are also present in the lower Anisian deposits in southern Sardinia, interlayered with limestone and brecciated dolostone (Cirilli et al., 1998)

\section{Upper Triassic}

During Upper Triassic, passive-margin conditions affected a large part of the Tethys basin with the development of carbonate platforms that, during the earlier phases, allowed the formation of wide shallow lagoons where precipitation of sulphate and evaporitic dolomites occurred (Passeri, 1975). Chronologically we can recognise three evaporitic events: the "Keuper" facies deposits cropping out in the Ligurian Alps and in western Sardinia, the Carnian deposits of the Alps and Gargano, and the Norian phase widely spread in the Northern Apennines (Cucchi \& Piano, 2003).

The "Keuper" is characterised by clastic facies consisting of dolomite, marly limestone and gypsumsulphur lenses, locally with chaotic structure. In the 
eastern Alps, the Raibl Formation (Upper Carnian) consists of three members: at the bottom, the red siltstones Member with a thickness between 10 and $80 \mathrm{~m}$; the intermediate member is characterised by saccharoid gypsum, white and grey in color rich in clayey impurities and grey dolomites having a thickness of $350 \mathrm{~m}$; the upper member is made of dolomites and marls having a thickness of $180 \mathrm{~m}$ (Venturini, 2001). Currently, only in the northern Apennines Upper Triassic evaporites form significant surface outcrops (of a few $\mathrm{km}^{2}$ ).

In the whole northern Apennines, the Liassic carbonate sequences lay on an evaporitic succession made up of anhydrite interlayered with dolomitic beds. This formation is named "Anidriti di Burano" and is found in its original facies only in deep boreholes, whereas it displays a brecciated and tectonised structure at the outcrops (Burano Evaporites). The Burano Formation is referred to a sabkha type environment, which developed on almost all the northern Apennine domains before the formation of the Jurassic carbonate platforms (Martini et al., 1989; Ciarapica, 1994).

The "Anidriti di Burano" Formation was described by Martinis \& Pieri (1964) using data obtained from AGIP oil exploration surveys, then revised by Passeri (1975), who defined the depositional environment. Outcrops are found in Tuscany, Emilia-Romagna, and in Umbria, and in the subsoil in Tuscany, Umbria, Latium, Marche, and Apulia (Gargano).

The typical (primary) facies of this formation mainly consists of anhydrite, dolomite and dolomitic limestone, locally associated with marls, shales and rock salt. Anhydrite, white, brown or pinkish in color, is well crystallised and often contains clay or thin bituminous layers. The lithofacies is represented by sulphate-carbonate layers or lenticular aggregates dispersed in the crystalline carbonate mass.

Hazel, brownish or blackish dolomite is normally very fine-grained and microcrystalline and contains thin veils of clayey bituminous substances: the lithofacies is represented by carbonate breccias.

During burial, the unit experienced diagenetic transformation (Ciarapica \& Passeri, 1976). Strong tectonics affected these evaporites during the Apennine orogenesis, resulting in a limited lateral continuity of the sedimentary succession. Thus, the reconstruction of the general stratigraphy from outcrop observations is particularly complicated.

The thickness of the Burano Formation is very variable for tectonic reasons. In boreholes, the thickness varies from at least 1,700 metres (Foresta Umbra in Gargano, Antrodoco in Central Italy) to some hundreds of metres (near Pomarance, Southern Tuscany). Stratigraphically, the Burano Formation rests on phyllites and quartz-arenites interbedded with dolomite and anhydrite (Tocchi Formation), or on the Phyllites of Boccheggiano. The top is represented by the Rhaetavicula contorta Limestone or by the "Calcare Massiccio".

The Burano Formation had an important role during the Apennine orogenesis, acting as a major detachment horizon of the main tectonic nappes.
During orogenesis the Burano evaporites were intensively fractured and hydrated, forming an autoclastic breccia that now crops out as a calcareousdolomitic breccia without sulphates. The most common lithofacies identifiable in outcrop are late dissolution breccias. These lithologies were produced by surface weathering that caused the complete dissolution of the sulphates and the de-dolomitization of the calcareous terms, forming the typical structure of the "Calcare Cavernoso" (Gandin et al., 2000).

In the Northern Apennines (Secchia River Valley and Val Rosaro area) the Burano Formation is an up to 2,200 m-thick sequence consisting of metreto-decametre layers of gypsum/anhydrite and dolostones with minor levels of halite. The deposit has been affected by an intense post-depositional change, thermal events and large-scale dissolution (Lugli, 2001). In southern Tuscany, Burano Evaporites only occur in restricted areas, whereas at outcrops the formation is substituted by carbonate tectonic/ sedimentary breccias generally mapped as Calcare Cavernoso (Martini et al., 1989).

\section{Miocene (Messinian)}

Most of the gypsum outcrops occurring in the Italian peninsula belong to the Gessoso-Solfifera Formation (GSF) of Messinian age. This formation is typical of almost all the palaeogeographic domains of the Apennine chain, from Piedmont to Sicily, and is the main geological evidence of the "Messinian salinity crisis" (MSC), a peculiar climatic/physiographic circumstance that modified the connection between the Atlantic Ocean and the Mediterranean Sea (Hsü et al, 1977; Roveri et al., 2001). The MSC occurred during an intense phase of geodynamic reorganisation of the Mediterranean area that also produced the fragmentation of the former Miocene Apennine foredeep basin. In this area, primary shallow-water evaporites, equivalent to the Mediterranean Lower Evaporites, apparently only formed in semi-closed thrust-top basins like the Vena del Gesso Basin. The subsequent uplift and subaerial exposure of such basins ended the evaporite precipitation and promoted a widespread phase of collapse leading to the re-sedimentation of the evaporites into deeper basins.

Based on the Apennine basin experience, it is suggested here that evaporites, widespread along the deeper portions of the Mediterranean basin, may consist mainly of deep-water re-sedimented deposits rather than shallow-water to supratidal primary evaporites indicative of a complete basin desiccation (Testa \& Lugli, 2000).

The most complete succession of GSF crops out in central Sicily. Here we find two evaporitic successions laying upon pelitic facies of the Terravecchia Formation and locally on white diatomitic marls (Tripoli Formation), and covered by fine pelagic sediments (Trubi Formation). The lower evaporitic unit consists of evaporitic limestone, crystalline gypsum interlayered with gypsy marls and salts (mainly chlorides). The upper evaporitic unit consists of crystalline gypsum, primary or clastic, bioclastic limestone and, finally, clayey sands (Catalano, 1986). 
The Upper Gypsum unit of the Caltanissetta Basin testifies the last phase of the MSC (Manzi et al. 2009). Several depositional cycles consisting of primary gypsum bodies can be recognised. A basal thin gypsum bed is overlain by five thick gypsum bodies, which are separated from the uppermost gypsum body by a marl-sandstone horizon. The terrigenous Arenazzolo Formation forms the uppermost part of the Upper Gypsum unit (Manzi et al., 2009).

At a basin scale, the Upper Gypsum unit unconformably overlies a mainly clastic evaporite unit containing carbonate breccia (the so-called 'Calcare di Base') and/or clastic gypsum. Towards the basin centre a primary gypsum horizon is present. This layer is interpreted as a possible lateral equivalent of the Halite unit present only in the deepest depocentres (Manzi et al., 2009).

In the Northern-central Apennine the GSF is usually made of three different sedimentary units (Roveri et al., 2001). The lower unit consists of turbiditic gypsum-arenites, locally completely re-crystallised, interlayered with dark and bitumen-rich pelite. The middle unit is made of grey pelites with gypsumarenite levels. The upper unit consists of a chaotic complex with pelitic layers and clasts and nodules of gypsum, which are covered by gypsum-arenite facies.

Due to the high recrystallization processes usually affecting gypsum layers, original depositional structures and textures are often obliterated. Notwithstanding, the GSF in the northern Apennines is now interpreted with a deep-water clastic genetic model that describes the down-current evolution of a turbidite flow mainly composed of gypsum clasts. Gravity-driven deposits ranging from debris flow to low-density turbidites can be recognised and layers previously considered as deep-water primary deposits are now interpreted as the fine-grained product of high to low-density gravity flows (Testa \& Lugli, 2000).

In northern Italy, Messinian evaporites are restricted to some minor areas inside the "Bacino Terziario Piemontese". Here the gypsum occurs as lenticular bodies, with moderate thickness, enclosed into claymarly deposits (Dela Pierre et al., 2011).

\section{SURFACE KARST FEATURES}

\section{Large-scale morphologies}

In Italy the gypsum karst landscapes are different and complex considering the various geological, environmental and climatic conditions characterising the country. From the morpho-structural standpoint, the most common styles are tabular plateaux, homoclinal ridges, fault scarps, folded relief, and isolated large gypsum blocks surrounded by clays (Forti \& Sauro, 1996). The geomorphological settings are often the result of important relief inversion phenomena (Vattano, 2008; Lucci \& Rossi, 2011). In addition, hilly, fluvial, lacustrine and coastal environments are recognisable (Sauro, 2003a; Madonia $\&$ Sauro, 2009). In many areas the transition between fluvial and karst processes is evident and results in the development of a hydrographic surface network connected with a subterranean hydrography. This is the consequence of contact karst due to: i) vertical transition from impervious rocks to soluble rocks (i.e., Santa Ninfa, Sicily; Vena del Gesso, Emilia Romagna; Verzino area, Calabria) (Fig. 5); ii) lateral tectonic contact between soluble and insoluble rocks (i.e., central and southern Sicily); iii) thin and discontinuous clastic covers of different permeability over the gypsum rock (e.g., Ciminna Basin, NW Sicily) (Agnesi \& Macaluso, 1989; Forti \& Sauro, 1996, Madonia \& Forti, 2003; Parise \& Trocino, 2005; Vattano, 2008).

The surface karst landforms prevail where gypsum outcrops extensively, such as in Sicily, EmiliaRomagna and Calabria (Verzino area), nevertheless surface karst forms occur in many parts of Italy, also where gypsum formations are mantled (Marinelli, 1917; Madonia \& Forti, 2003). Surface karst features show a large variety of typologies, ranging in size from a few microns to some kilometres. Medium and large-scale landforms are represented by dolines or sinkholes (Fig. 6A-B). Dolines vary from a few metres to several hundreds of metres in average diameter and from a few decimetres to tens of metres in depth. They are of different shapes: cylindrical, conical, truncated-conical, hemispherical, irregular, and asymmetrical. Impressive cylindrical-shaped collapses can be identified in Friuli Venezia Giulia in the area of Sauris, even if more common are the mediumsmall size collapses or suffosion sinkholes usually linked to the presence of tectonic features. Large truncated-conical dolines are present in EmiliaRomagna (i.e., Spipola, Budriolo) (Figs. 5 and 6G) and central and southwestern Sicily. Asymmetrical dolines show a significant difference between maximum and minimum depth (Fig. 6B) and are generally elongated according to the slope, or developed at the contact of different rocks; sometimes these dolines are transition forms to blind valleys (Fig. 6C and E). They are widespread in Sicily and Calabria (Verzino area) (Agnesi \& Macaluso, 1989; Sauro, 1996; Meneghel, 1998; Parise \& Trocino, 2005; Vattano, 2008; Di Maggio et al., 2012). Complex forms deriving from the merging of simpler features occur as well.

Considering the formation processes, where gypsum crops out, solutional dolines (point recharge-type; Sauro, 2003b; Ford \& Williams, 2007) are mainly found. These dolines present a swallow hole at the bottom or at the foot of a slope (Fig. 6B-C), which often gives access to important subterranean systems (e.g., the Spipola doline in Emilia Romagna) (Fig. 6G). In Tuscany, in a small area of Messinian gypsum close to the Montecatini Val di Cecina village (Pisa province), some well developed solutional dolines occur (Stefanini, 1907). They have a symmetrical shape and where gypsum is covered by alluvial deposits some of them have a suffosional origin (at least partially). Small collapse pits, only some metres deep, are also present.

Drawdown dolines are less common because in gypsum the classical epikarst is missing or limited (Ferrarese et al., 2002; Sauro, 2003b). Typical collapse dolines (Sauro, 2003b) or bedrock collapse sinkholes (sensu Gutiérrez et al., 2008, 2014) with vertical 

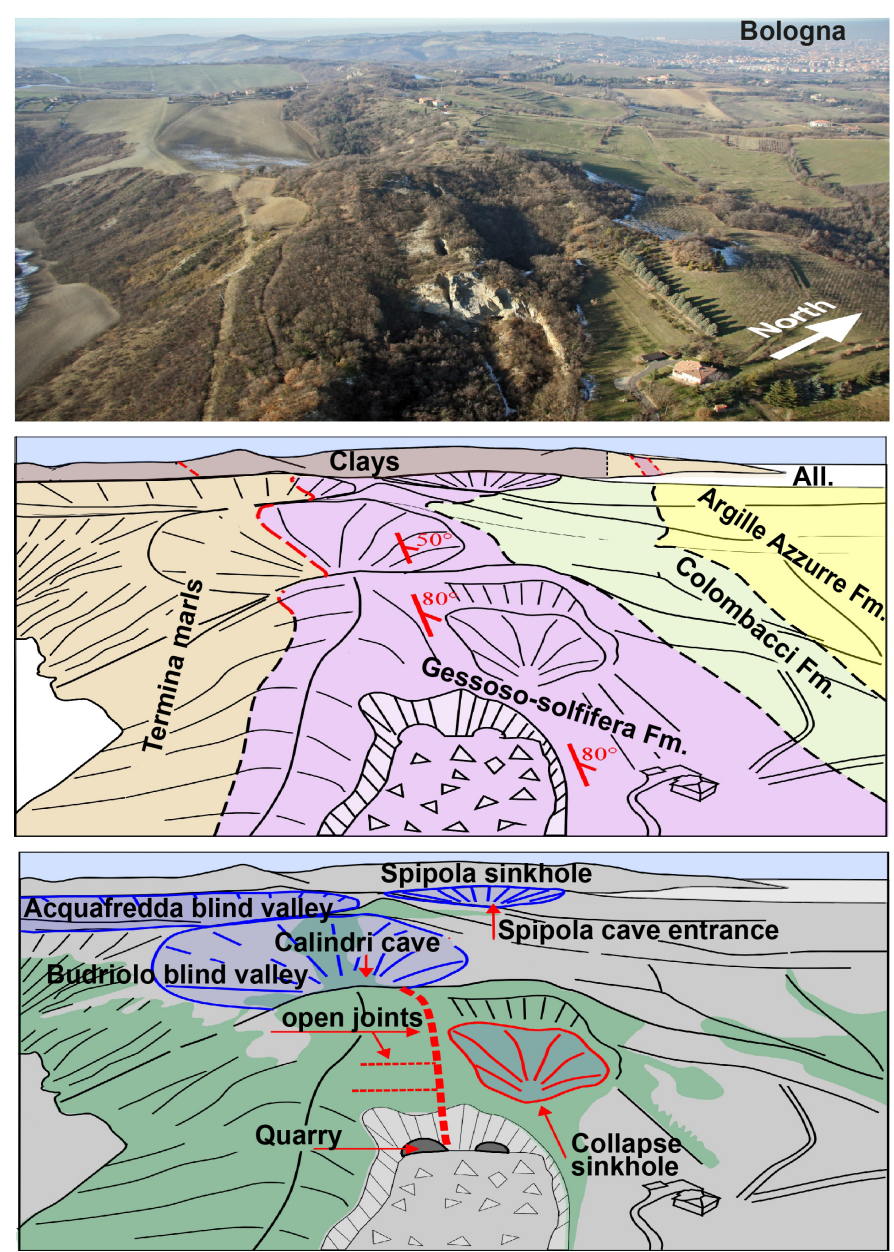

Fig. 5. An aerial view on the gypsum ridge southeast of Bologna (above, photo Giovanni Bertolini), the geological framework (middle) and the main geomorphological elements (below). All. = alluvium (modified from Demaria et al., 2012).

walls and depth of tens of metres involve the Permian Bellerophon Formation in the Tagliamento River Valley (Friuli-Venezia Giulia region) (Calligaris et al., 2010, 2015, 2017; Zini et al., 2015a, b), the Triassic evaporites in the Secchia valley (Emilia-Romagna region) (Madonia \& Forti, 2003), and the Messinian gypsum in the Verzino area (Calabria region) (Parise \& Trocino, 2005; Iovine et al., 2010).

Cover and subsidence dolines (sensu Sauro, 2003) are frequent in many regions where gypsum formations are overlain by insoluble rock successions of different lithologies, thickness and age. Cover dolines (or cover collapse sinkholes and cover suffosion sinkholes sensu Gutiérrez et al., 2008, 2014) are present in the Triassic Werfen Formation in Friuli Venezia Giulia (Calligaris et al., 2015; Zini et al., 2015a, b) and Veneto (Dolomites) (Madonia \& Forti, 2003; Arziliero et al., 2004) regions where Permian and Triassic gypsum are mantled by Quaternary glacial till, morenic, alluvial and colluvial deposits, and in Piedmont (Monferrato area) where Messinian gypsum occurs as lenticular bodies within clay-marly deposits, and is covered by marine Plio-Pleistocene formations or Quaternary alluvial and colluvial deposits (Fioraso et al., 2004; Vigna et al., 2010a, b). Quaternary terrace deposits overlying the Messinian gypsum are affected by large and shallow cover sagging sinkholes in the southern coastal area of Sicily (Vattano, 2008; Di Maggio et al., 2010). Subsidence dolines (or caprock sagging sinkholes and caprock collapse sinkholes sensu Gutiérrez et al., 2008, 2014) involve the Pliocene and Pleistocene formations overlying the Messinian evaporites in western and southern coastal areas of Sicily (Madonia \& Forti, 2003). These latter karst depressions may host small ponds, such as Lago Preola and Gorghi Tondi (Trevisan \& Di Napoli, 1937; Hauser et al., 2002), Soprano, Medio and Sottano lakes (Di Maggio et al., 2010). Cover and subsidence dolines may be triggered also by anthropic activities and often may represent a significant hazard in many areas (see the subchapter on Hazards in gypsum karst).

The spatial distribution of dolines varies from isolated to clustered forms to alignments of forms. Frequently, doline distribution follows discontinuity systems in the evaporites (Madonia \& Forti, 2003; Parise \& Trocino, 2005; Zini et al., 2015a). In some areas of Sicily and Calabria, chains of aligned point-
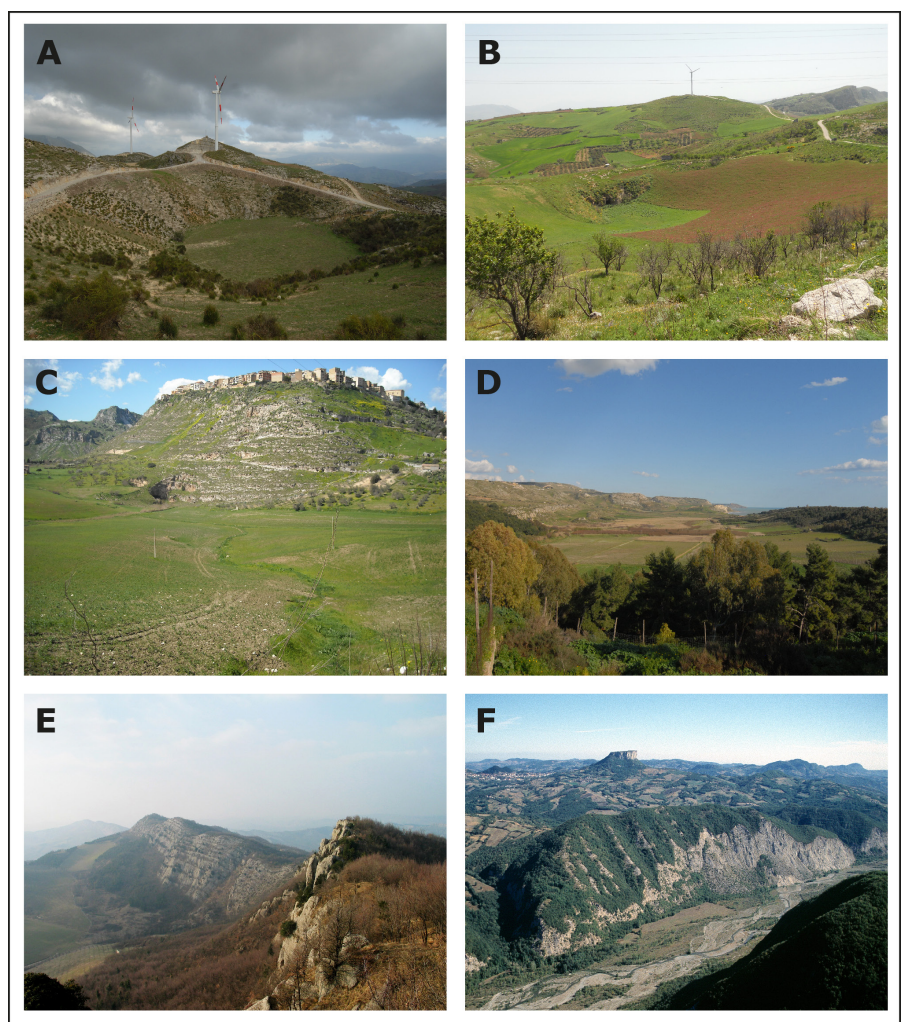

G

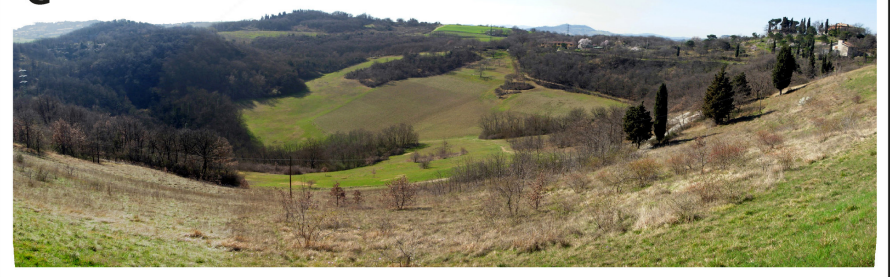

Fig. 6. Large forms in Italian evaporite areas. A) Truncated-conical solution drawdown doline in selenite gypsum (Monte Misciotto, NW Sicily); B) Asymmetrical dolines with intermediate features between doline and blind valley (Ciminna Basin, NW Sicily); C) Blind valley cut in clayey rocks ending at the foot of a selenite gypsum relief where the Grotta di Sant'Angelo Muxaro opens (Sant'Angelo Muxaro, centralwestern Sicily); D) Gypsum polje developed in a faulted syncline depression (Siculiana, south-central Sicily); E) The Vena del Gypsum ridge with its visible gypsum beds and the blind valley of Rio Stella (Romagna); F) The Secchia River cutting the Triassic anhydrites (Reggio Emilia); G) The Spipola Doline in the gypsum outcrops South of Bologna. (Photos A, C-D: Marco Vattano; B: Antonino Lo Bello; E: Piero Lucci; F: Giovanni Bertolini; G: Jo De Waele). 
recharge dolines, formed as a consequence of an upstream migration of the swallets of small blind valleys, follow the pattern of old fluvial networks that developed on the impervious cover (Agnesi \& Macaluso, 1989; Sauro, 1996; Ferrarese \& Sauro, 2001; Parise $\&$ Trocino, 2005). Dolines are often grouped in welldefined karst units, where they occupy the entire karst area to form a honeycomb pattern, as in the Santa Ninfa area (Sicily) (Agnesi \& Macaluso, 1989; Sauro, 1996, 2003b). Clusters of tens of small dolines occur in the western Alps (Moncenisio area) (Sauro, 1996 ) and in the Dolomites (Marinelli, 1917; Madonia \& Forti, 2003).

Large polje-type karst depressions are less common (Fig. 6D). They occur mainly in southern coastal areas of Sicily, near Agrigento. They are characterised by a flat bottom surface, mantled by alluvial and lacustrine deposits, bounded by steep gypsum slopes. Generally, they are open, occasionally active depressions and their genesis seems to be strongly controlled by tectonic structure (Sauro, 1996; Vattano, 2008; Di Maggio et al., 2016b).

Fluvial and karst processes coexist in many Messinian gypsum areas of Sicily, Emilia-Romagna and Calabria with the development of several blind valleys up to a few kilometers long. Most of these valleys are cut in insoluble rocks and end blindly at a gypsum threshold; others have their upstream part on insoluble rocks and the downstream end incised in the gypsum. Some blind valleys are almost entirely cut in gypsum. At the base of the gypsum threshold one or more active swallow holes are often points of recharge for important cave systems (i.e., Monte Conca, Santa Ninfa caves, S. Angelo Muxaro in Sicily; Rio Stella-Rio Basino in Emilia-Romagna) (Sauro, 1996; Madonia \& Forti, 2003; Vattano, 2008; Lucci \& Rossi, 2011; Madonia \& Vattano, 2011; Vattano et al., 2015). Sometimes, headward erosion leads to the formation of deep and narrow pocket valleys (few hundred metres long) where the resurgences of subterranean streams are present (i.e., Rio Basino, in Emilia Romagna) (Lucci \& Rossi, 2011). When rivers are big enough they can cut the entire evaporite outcrops, forming valleys with almost vertical slopes (e.g., Upper Secchia Valley, Reggio Emilia) (Fig. 6F).

\section{Small-scale morphologies}

As far as the small karst forms in Italy are concerned, gypsum rocks show a large variety of karren occurring mainly on the exposed surfaces, but also under permeable covers. Many forms are similar to limestone karren and their genesis is mostly controlled by the dynamics of water flowing on the gypsum surfaces (Macaluso \& Sauro, 1996a, b; Madonia \& Sauro 2009). Karren developed in all the Messinian outcrops show the largest diffusion and variability in Sicily (Macaluso \& Sauro, 1996a, b; Macaluso et al., 2001; Madonia \& Sauro, 2009), and Calabria (Macaluso \& Sauro, 1998). Karren are also well-developed on the Triassic microcrystalline gypsum outcrops in the Upper Secchia Valley region (Chiesi \& Forti, 2009; Chiesi et al., 2013). The karren features develop in several environments both on extended slopes and small isolated blocks. Peculiar karren have been recognised in the fluvial and coastal environments, and in some anthropic areas such as quarries and dry-stone walls (Macaluso et al., 2001; Madonia \& Sauro, 2009). In most cases karren features are grouped in complex associations of more different elementary forms.

Gypsum karren range from the nano- and the microforms to the large morphologies (Macaluso $\&$ Sauro, 1996a). The nanoforms develop on large selenite gypsum crystals and are closely controlled by the crystalline structure (Forti, 1996). The microand small forms are the most widespread and varied karren, and are mainly developed on microcrystalline gypsum or fine-grained gypsum lithofacies (Fig. 7A-D). On selenite macrocrystalline gypsum the large forms are the most frequent; solution runnels may occupy entire slopes and their development is frequently influenced by the crystalline structure, or by the bedding planes (Agnesi \& Macaluso, 1989). In selenite gypsum of Emilia-Romagna vertical wallkarren (candele) up to $10 \mathrm{~m}$ high develop around the swallow holes of important cave systems (Capellini, 1876) (Fig. 7E).

Covered karren form only where the gypsum rock is mantled by highly permeable soil or cover which allows a rapid flowing of water at the rock-cover interface (Fig. 7F-G). Covered runnels are widespread in many areas of Sicily and Emilia-Romagna. Gypsum pavements, such as gypsum tables separated by grikes and corridors, or pinnacles are quite rare (north and south-central Sicily). Soil patches may favour water decantation allowing the formation of peculiar karren, as runnels, rills and meandering rills on steep slopes.

The biological activity sometimes plays a protective role on the rocky surface; i.e., on microcrystalline and fine-grained gypsum the colonisation of pioneer vegetation favours the formation of small knobs and circular enclosures surrounding closed depressions (Macaluso \& Sauro, 1996; Macaluso et al., 2001) (Fig. $7 \mathrm{H}$ ).

On bare gypsum surfaces lacking soil cover, solution and recrystallisation processes linked to seasonal rainfall supply and evaporation are responsible for the development of a gypsum weathering crust characterised by many different forms, such as gypsum tumuli (Fig. 7I), pressure ridges, pressure humps, and other related small forms (Macaluso \& Sauro, 1996b; 1998; Calaforra \& Pulido Bosh, 1999; Ferrarese et al., 2002). These forms are widely diffused in many selenite gypsum outcrops of Sicily and Emilia-Romagna. In many areas of Sicily the gypsum weathering crust may also lead to the formation of mega-tumuli and dome-like hills (Ferrarese et al., 2002).

\section{GYPSUM CAVES}

The largest and also most explored gypsum outcrops are located mainly in Sicily, Calabria, EmiliaRomagna, and Piedmont, while some minor cave areas are known in Marche, Abruzzo, and Tuscany (Madonia \& Forti, 2003). The longest cave systems 


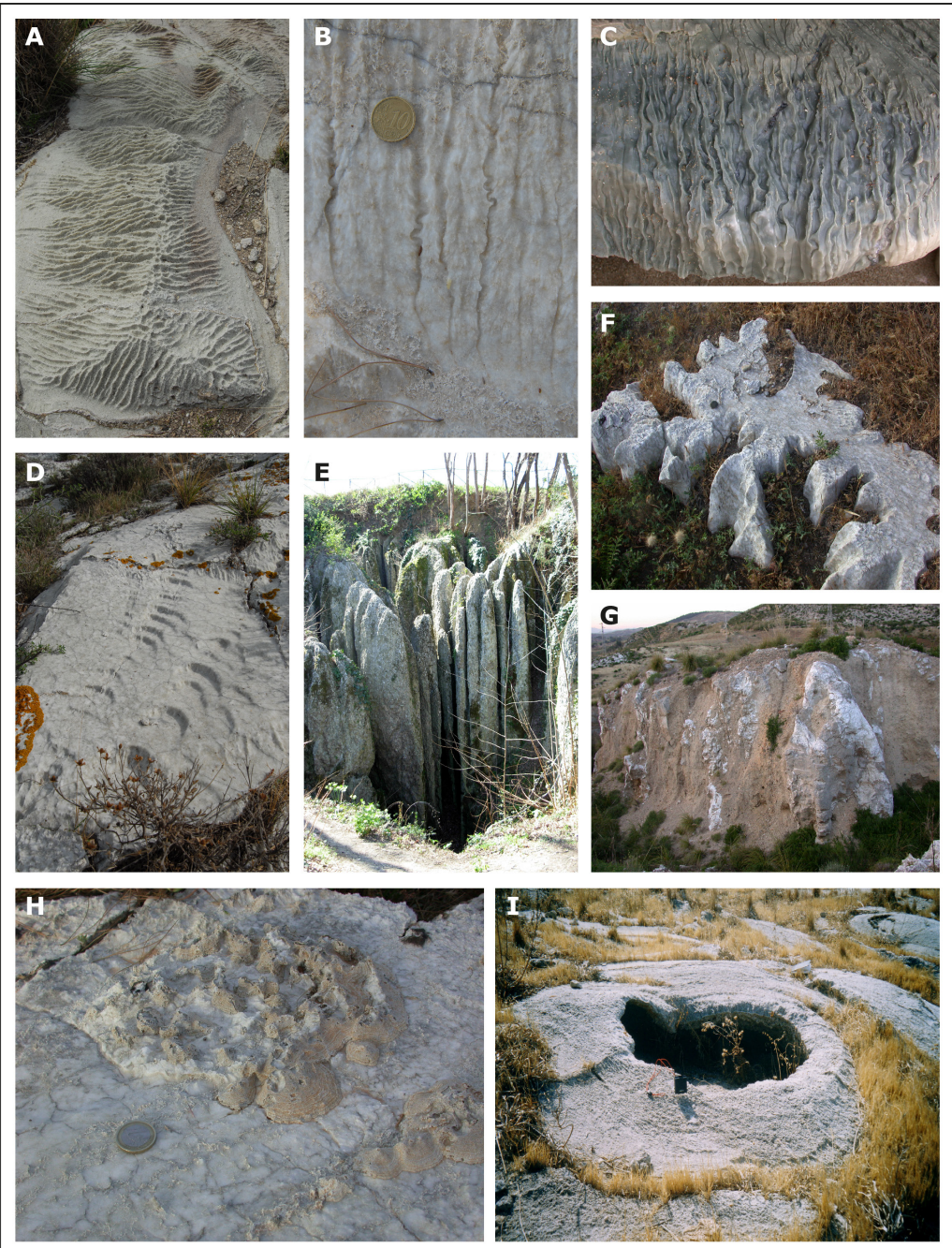

Fig. 7. Typical karren on gypsum outcrops. A) Assemblage of elementary karren features on gypsum arenite: rain pits, rills, solution bevels and decantation runnels are recognisable (Sant'Angelo Muxaro, central-western Sicily); B) Meandering microrills on microcrystalline gypsum (Montallegro, south-central Sicily); C) Coastal karren features on laminite gypsum due to the wave splash erosion and decantation processes (Marina di Palma di Montechiaro south-central Sicily); D) Heelsteps on microcrystalline gypsum (Montallegro, south-central Sicily); E) The famous "Candele" (wallkarren) in the macrocrystalline gyspum rocks of the Parco dei Gessi South of Bologna; F) Rounded runnels on microcrystalline gypsum formed under soil cover. On the top surface rain pits, rills and ridges are visible (Montallegro, south-central Sicily); G) Gypsum pinnacles separated by grikes formed under a Pleistocene permeable marine terrace cover (Siculiana, south-central Sicily); H) Small knobs and circular enclosures surrounding closed depressions on microcrystalline gypsum due to the protective action by lichen colonies (Montallegro, south-central Sicily); I) Tumulus field on selenite gypsum (Palma di Montechiaro south-central Sicily) (Photos A-D and F-H: Marco Vattano, E: Jo De Waele; I: Marianna Gangi).

are all located in Emilia-Romagna, with the SpipolaAquafredda cave system (near Bologna) being the longest, with almost $11 \mathrm{~km}$ of development (Demaria et al., 2012) (Fig. 8), followed by the Re Tiberio system (Vena del Gesso Romagnola, over $8 \mathrm{~km}$ ) (Ercolani et al., 2013), and the Rio Stella-Rio Basino Cave (vena del Gesso Romagnola, around $5 \mathrm{~km}$ long) (Forti \& Lucci, 2010). Other long caves are Grave GrubboVallone Cufalo in Calabria (around $5 \mathrm{~km}$ ) (Ferrini, 1998; Parise \& Trocino, 2005), Monte Conca $(2.5 \mathrm{~km})$ (Madonia \& Vattano, 2011), Sant'Angelo Muxaro (1.7 $\mathrm{km})$ (Vattano et al., 2015), and Santa Ninfa caves (1.5 $\mathrm{km}$ ) in Sicily (Agnesi \& Macaluso, 1989).

The deepest epigenic karst system, being also the deepest gypsum cave in the world, is the Monte Caldina cave in the Upper Secchia Valley (Reggio Emilia), reaching a depth of $265 \mathrm{~m}$ (Franchi \& Casadei, 1999).
In the Rosaro Valley (Sassalbo, Tuscany) we find one of the highest altitude evaporite karsts in Italy. Here, gypsum outcrops were locally affected by glacial processes, which destroyed previous surface forms and covered them with moraine deposits (Zaccagna, 1932). Caves, the longest of which is $450 \mathrm{~m}$, testify a water circulation probably influenced by the evolution of the small glacier that occupied the high portion of the Rosaro Valley. Glacial deposits also occur in caves and probably had a relevant role in speleogenesis, enhancing erosion processes during wet interstadial phases (Piccini, 2003).

Most caves are typical epigenic throughflow systems, with a sinking stream and a resurgence (Fig. 9A). Only in Piedmont a couple of caves are of the intrastratal type, formed by rising waters (hypogenic caves sensu Klimchouk, 2007, 2009) (Vigna et al., 2010a, 2010b; Banzato et al., 2017). These last caves (i.e., Moncalvo, Monticello d'Alba) sometimes show maze patterns, similar to the Ukrainian caves, and signs of very slowly flowing waters. They contain solutional bevels related to old water table altitudes, phreatic morphologies and lack of alluvial sediments (Fig. 9B). On the other hand, underground streams, depositing abundant sediments, have carved all the other caves. The typical morphologies encountered in these epigenic cave systems are canyon-like passages (Fig. 9C), vadose shafts (connecting different levels in the systems) (Fig. 9D-E), and large collapse chambers (Fig. 9F). At a mesoscale, pendants (Fig. 9G) and ceiling channels (Fig. 9H) are well developed, sometimes decorating most of the cave's ceilings. In most cases the antigravitative erosion (sensu Pasini, 2009) is the main process responsible of the upward dissolution of the gypsum ceilings, leaving after erosion of the sediments wide voids or antigravitative canyons.

Also, primary sedimentary features are sometimes well preserved, such as the large gypsum cones (mammelloni), made of large selenite gypsum crystals that sunk into the soft marl-clays below (Fig. 9I).

\section{Speleothems}

Gypsum caves are normally less rich in chemical deposits with respect to the carbonate analogues, and the most often found minerals are gypsum and calcite (Fig. 10). Their relative abundance mainly depends on climate (Calaforra et al., 2008). In a temperate humid climate calcite speleothems prevail, while where evaporation dominates (in warmer and more arid conditions), gypsum speleothems become more abundant. The main mechanism leading to the formation of carbonate flowstones and concretions is the incongruent dissolution (Forti \& Rabbi, 1981).

Rainfall water infiltrating through the overlying soils takes up $\mathrm{CO}_{2}$ (and thus $\mathrm{HCO}_{3}^{-}$), and is further enriched in calcium and sulphate ions encountering 


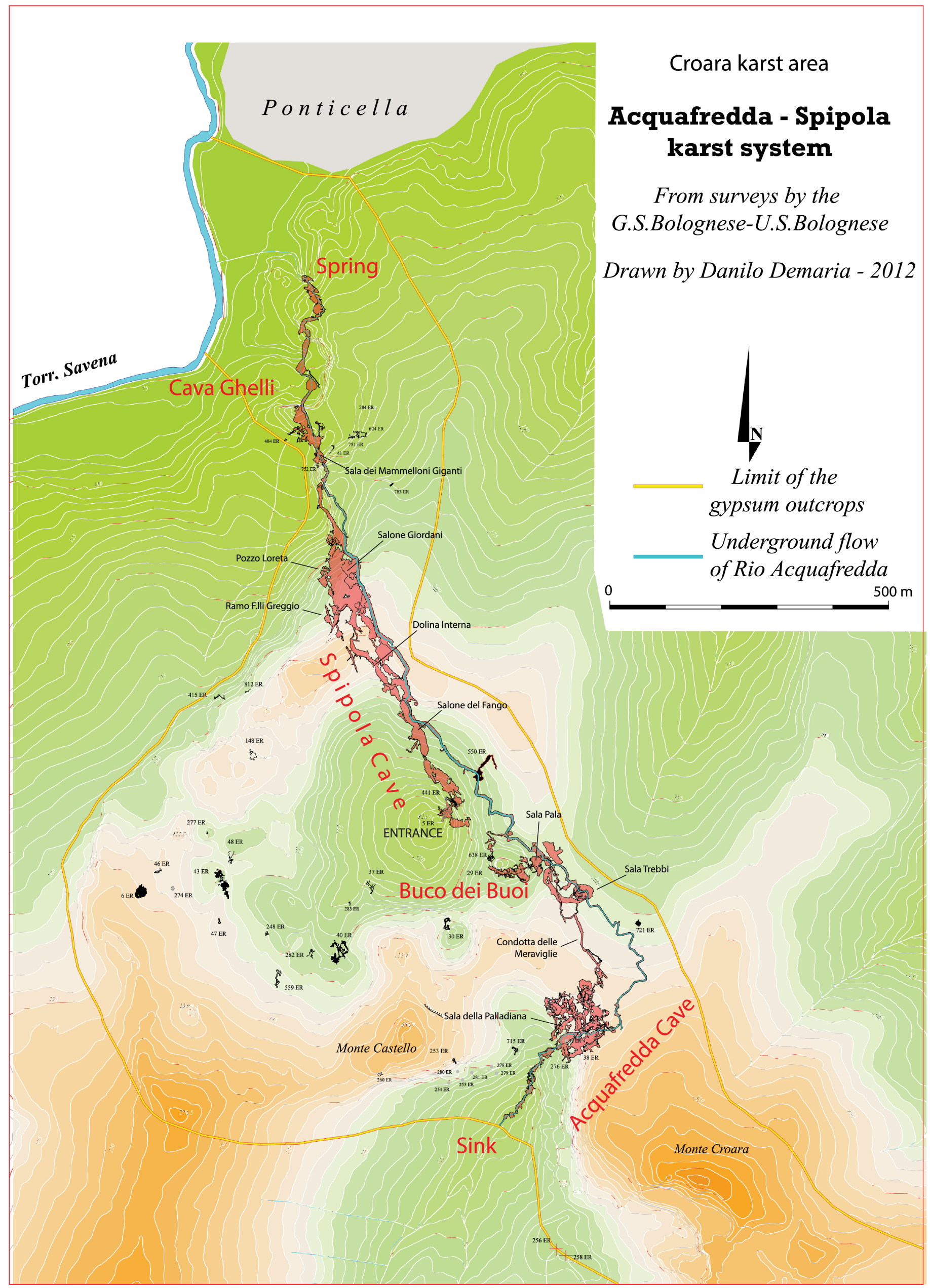

Fig. 8. Survey of the largest epigenic gypsum cave system in Italy. Spipola-Acquafredda, Bologna (Survey GSB/USB). 

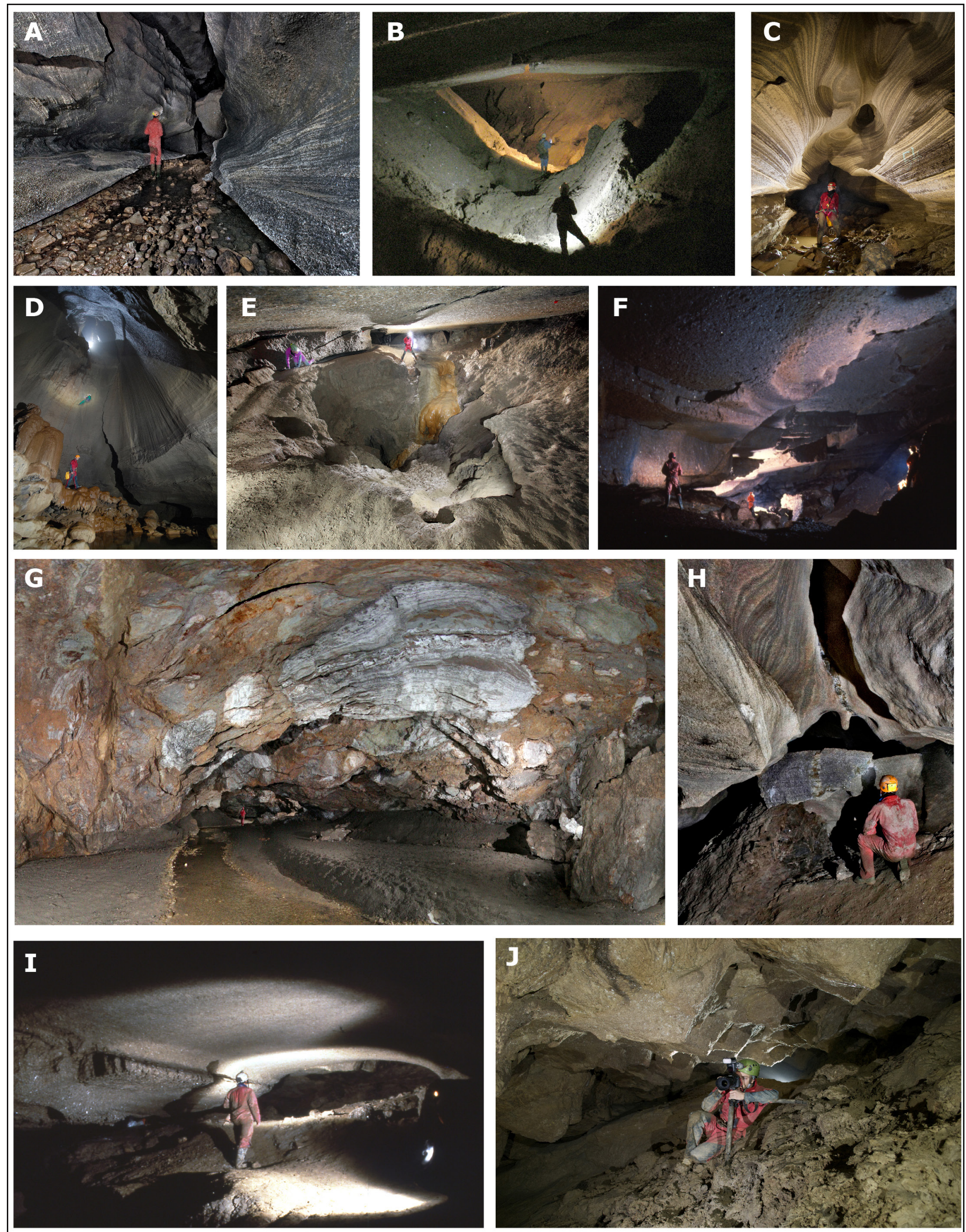

Fig. 9. Underground cave morphologies: A) Underground river in the Basino Cave system, Romagna; B) The phreatic cave passage with a flat beveled ceiling in the Moncalvo Cave, Piedmont; C) Passage of the lower gallery of the Monte Conca Cave with evorsion ceiling cupolas (southerncentral Sicily); D) Waterfall shaft, $26 \mathrm{~m}$ deep, of the Monte Conca Cave with huge calcitic speleothems at the bottom; E) The internal doline with a vadose shaft connecting two levels in the Spipola Cave system; F) The Giordani chamber, one of the largest in gypsum in Italy, in Spipola Cave system; G) The underground in Tanone Cave, Reggio Emilia; H) A pendant in the centre of a ceiling channel in the Rio Basino cave system;

I) Ceiling channel in Spipola Cave; J) "mammellone" (gypsum cone) in the Buco dei Buoi Cave, South of Bologna. (Photos A, G and H: Piero Lucci; B: Bartolomeo Vigna; C-D: Marco Vattano; E: Francesco Grazioli; F: Paolo Forti, H: Michele Sivelli; J: Graziano Agolini). 
the gypsum bedrock, deriving from the rapid dissolution of the gypsum beds. When high $\mathrm{PCO}_{2}$ seepage reaches the cave atmosphere, degassing triggers the precipitation of $\mathrm{CaCO}_{3}$. Due to its greater solubility compared to calcite, gypsum $\left(\mathrm{CaSO}_{4} \cdot 2 \mathrm{H}_{2} \mathrm{O}\right)$ will only form if evaporation becomes more important than $\mathrm{CO}_{2}$ degassing, usually in presence of important air flows. Many types of carbonate speleothems have been described from the Italian gypsum caves, including common morphologies such as stalagmites (Fig. 10A), stalactites, and especially flowstones (Fig. 10B-D). Some rare speleothems such as the calcite bubbles and bladed draperies (see Forti, 2017), and also calcite cave pearls, which are much less abundant than in carbonate caves (Fig. 10F), have also been described. Gypsum stalactites are also reported: they form essentially by evaporation resulting in very irregular shapes and often without a feeding canal, and appear very irregular in shape (Fig. 10H). The deflected stalactites in gypsum, contrary to the calcite counterpart, grow against the airflow where evaporation is most intense. In general gypsum is found as efflorescences (Fig. 10G) or crystal bushes (Fig. 10I). Interested readers are invited to refer to Forti (2017) for a more detailed description of cave minerals and speleothems found in Italian gypsum caves.

\section{Carbonate speleothems in gypsum caves as palaeoclimate and palaeoenvironmental indicators}

Although the occurrence of carbonate speleothems in gypsum caves has been abundantly documented in the past (Forti \& Sauro, 1996; Forti, 1997; Hill \& Forti, 1997; Calaforra \& Forti, 1999; Calaforra et al., 2008), much less work has been dedicated in understanding their connection with palaeoclimate and palaeoenvironments, especially using rigid chronologies. To our knowledge, Calaforra et al. (2008) were the only ones discussing the climatic significance of speleothems sampled in gypsum caverns. Their study was based on the comparison between carbonate and gypsum speleothems, where the formation of the former was attributed to generally wetter conditions whereas the latter were thought to deposit under drier situations. However, the lack of chronological control limited a rigorous correlation with past climate stages, hence their potential as a tool for palaeoclimatic and palaeo-environmental reconstructions still remains unexplored. This is at odds with the fact that carbonate speleothems from limestone caves have proved to be outstanding archives of palaeoclimatic-environmental information (i.e., Genty et al., 2003; Drysdale et al., 2009; Sniderman et al., 2016), and their importance in this science will probably increase in the next decades (Henderson, 2006).

Recently, the exploration of numerous gypsum caves carved in the Vena del Gesso (Vai \& Martini, 2001; Lugli et al., 2010) of Emilia-Romagna region (North Italy) and the Gessoso-Solfifera Formation (Madonia et al., 2016) of Sicily allowed the sampling of several carbonate speleothems. Speleothems were mostly recovered as already broken specimens and never removed from their original locations, in order to ensure cave conservation (Cigna \& Burri, 2000; Scroxton et al., 2016). Only in few cases core drilling was performed following the guidelines described in Spötl \& Mattey (2012). Six flowstones were collected at the Monte Tondo-Re Tiberio system (RTf, A50, 3A, RTy, PP and GO) (Columbu et al., 2015). Two flowstones and one stalagmite were sampled in the Spipola-Acquafredda (SpD, Sp1, and SpS) and Castelnuovo (Mor2, P2, and P3) karst systems, three other flowstones come from Rio Stella-Rio Basino karst system (RBT, RB1 and RB3), four flowstones and one stalagmite from Monte Mauro (MM4, MM2) (speleothem fragments found in the forest and probably belonging to a completely dissolved gypsum cave) and from Banditi Cave (Ba_Big, Ba1 and Ba2) (Columbu et al., 2017). In Sicily, four flowstones were cored at Santa Ninfa (SFN1 and SFN2), Rocca di Entella (ENTE 4) and Zubbia Cane (CANE 2) belonging respectively to Santa Ninfa, Entella and Sant'Angelo Muxaro gypsum karst areas. The predominance of flowstones over stalagmites is not a sampling bias: stalagmites are generally extremely rare in Italian gypsum karst (Columbu et al., 2017). Moreover, even flowstones are rather scarce, in comparison with welldecorated limestone caves at the same latitudes (i.e., Merino et al., 2014), and they are only found in isolated portions of the gypsum caverns.

All speleothems were dated with the UraniumThorium disequilibrium method (Hellstrom, 2003; Richards \& Dorale, 2003; Scholz \& Hoffmann, 2008) at the School of Earth Science - University of Melbourne, following the protocol set up in Hellstrom (2006) and improved in Drysdale et al. (2012).

Six speleothems (Rty, Sp1, SpS, RB3, SNF4, and CANE2) grew during the last three millennia of the Holocene (Marine Isotopic Stage 1, or MIS 1, after Emiliani, 1955) (Table 3). Six speleothems span from the middle (Mor2, RB1, RBT, and P3) to the early Holocene (GO and P2), while two flowstones almost cover the whole duration of the Holocene (SNF1 and ENTE4). Flowstones 3A, PP and A50 were deposited during short intervals of the transitional phase between the last interglacial and the last glacial (MIS $5 \mathrm{c}$ and $5 \mathrm{a}$ ); this lapse of time is characterised by the inception of Greenland Interstadial (GI) and Stadial (GS) oscillation (NGRIP project members, 2004), and the three speleothems correlate respectively with GI 24 and 21-20 (Columbu et al., 2015). Two speleothems (RTf and Ba_Big) mostly formed during the last interglacial. Flowstone $\mathrm{SpD}$ started growing during the last phase of the penultimate glaciation corresponding to MIS 8, but was mostly formed during the MIS 7e. MM4 and MM2 reported bottom ages much older than the top ages (MM4 during MIS 13 considering the average age, between MIS 11 to 15 considering the error); MM2 between MIS 9 and MIS 7e). Although intermediate ages between the bottom and the top are not available, petrographic evidence shows that the deposition of the carbonate was not continuous but characterised by growth interruptions. Finally, $\mathrm{Ba} 1$ and $\mathrm{Ba} 2$ report only one age each respectively at $>580 \mathrm{ka}$ (bottom age) and $378+29 /-20$ ka (top age). Ba2 might fit with the latest part of MIS 11, while Ba1 might be correlated with MIS 15. 

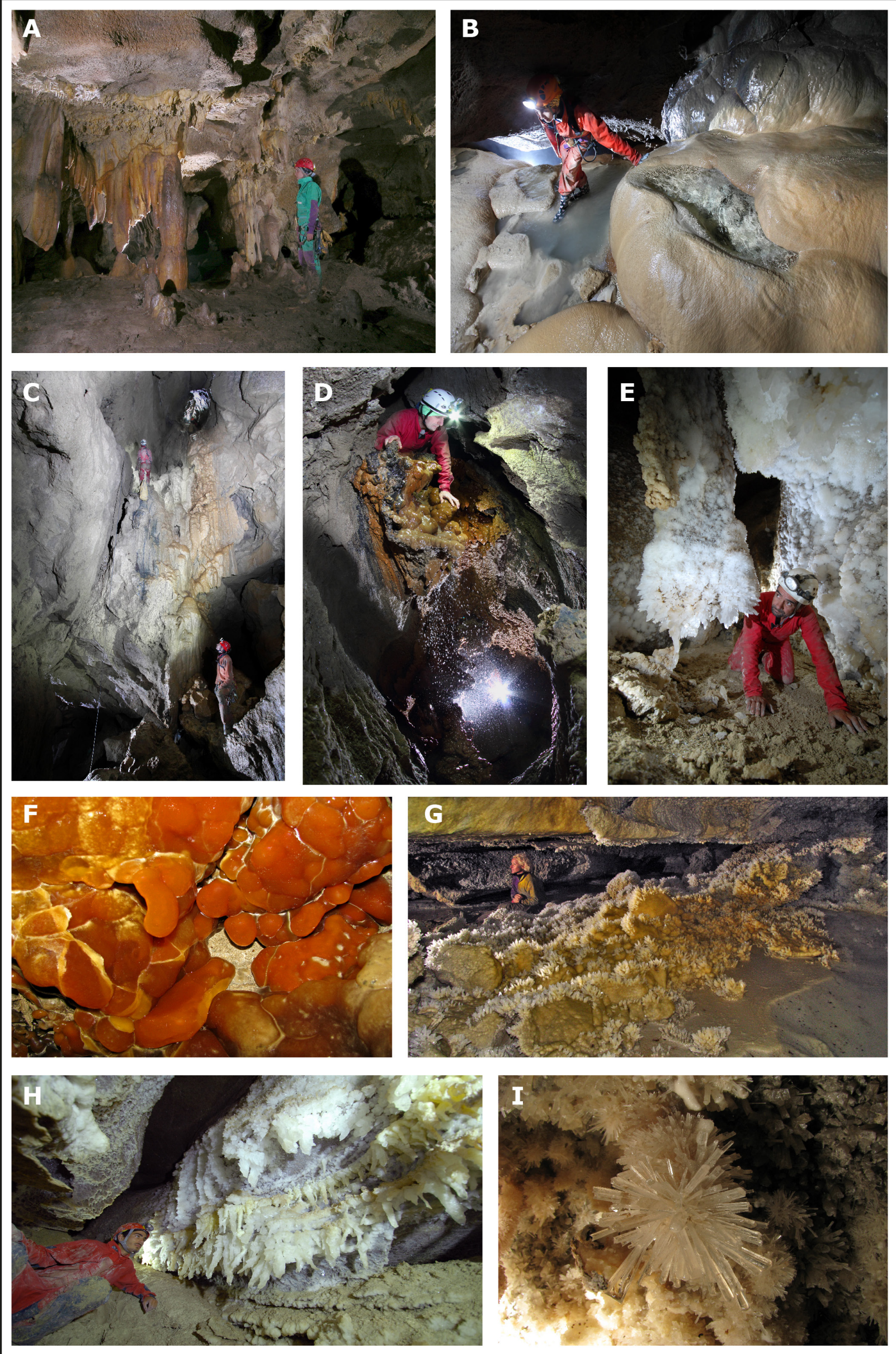

Fig. 10. Speleothems in gypsum caves. A) Stalagmites, stalactites and columns in the upper inactive gallery of the Santa Ninfa Cave (western Sicily); B-C) Flowstones in the Mornig Cave (Romagna) and, D) in Pelagalli Cave near Bologna; E and H) Big white gypsum crystals and speleothems in the Salinella cave (eastern Sicily); F) Orange calcite flowstone with white cave pearls, Rio Basino Cave (Romagna); G) Gypsum efflorescences on calcite flowstone in Rio Basino Cave; I) Radially growing gypsum needles in Befana Cave, East of Bologna (Photos A, E and H: Marco Vattano, B-D: Francesco Grazioli; F-G: Piero Lucci; I: Loris Garelli). 


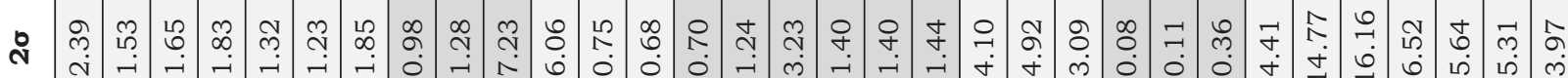

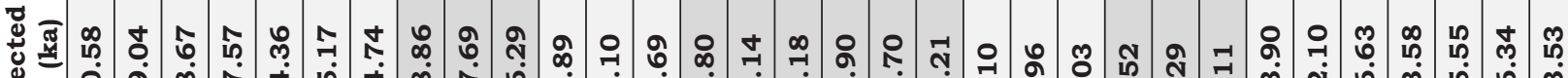

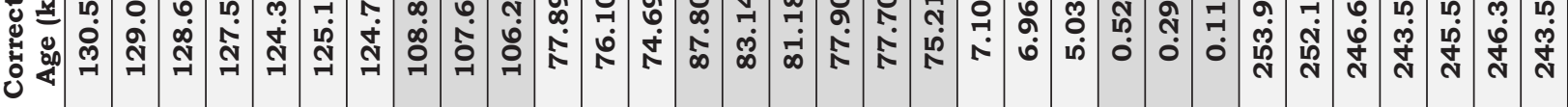

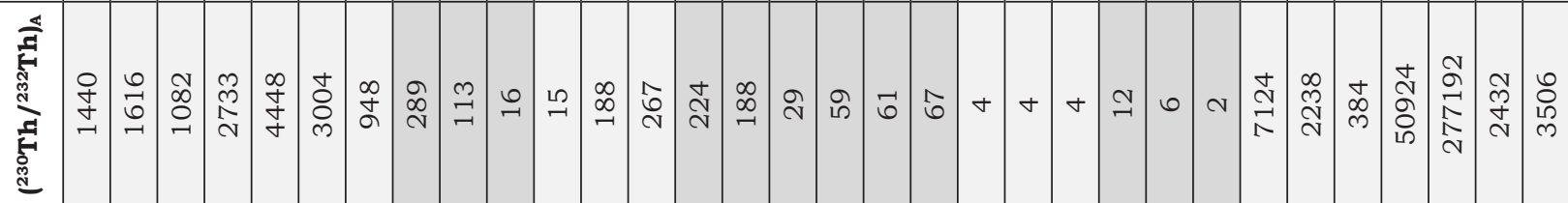

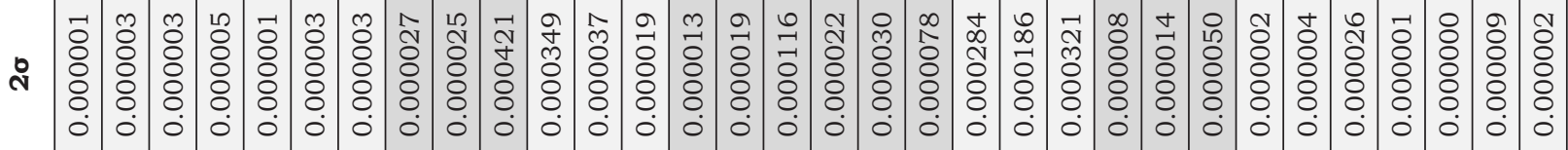

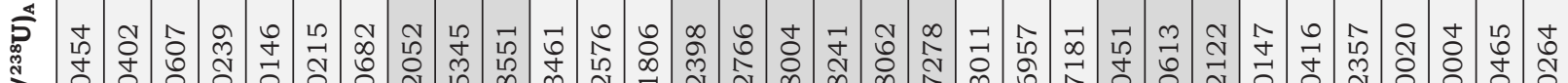

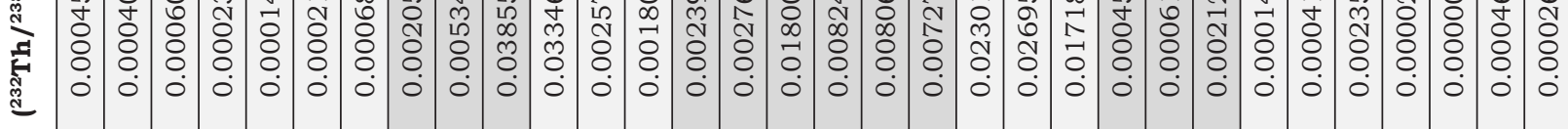

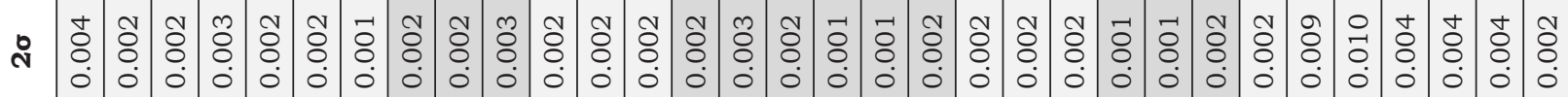

蛋

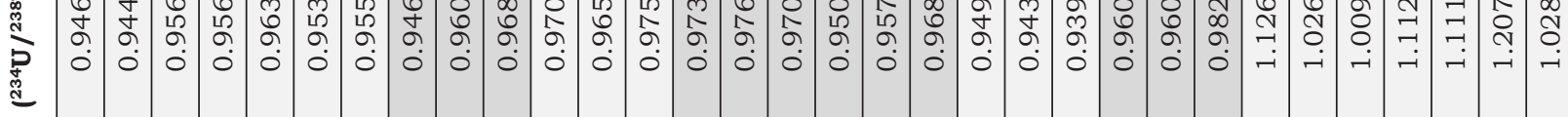

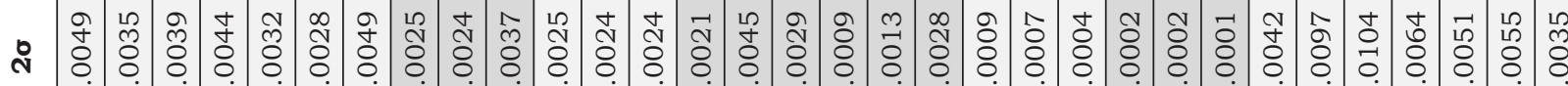

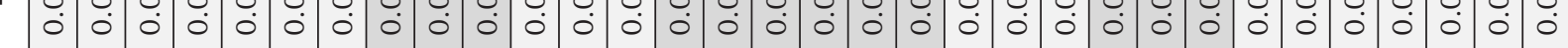

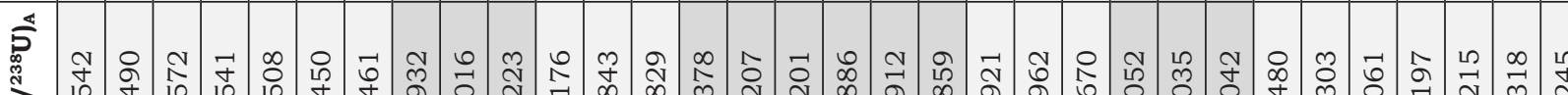

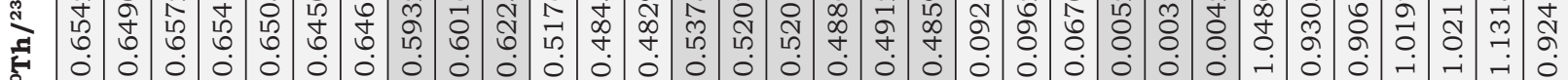

릴

$\stackrel{\pi}{=}$

芠

की

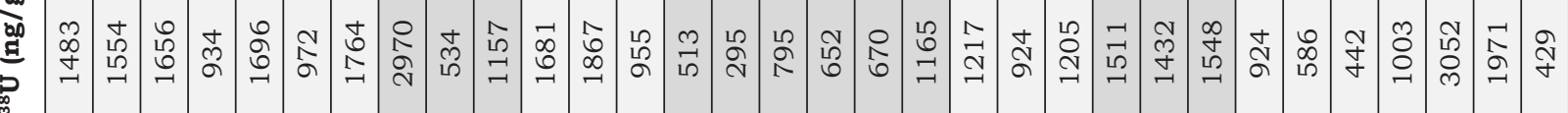
垔

$\stackrel{\oplus}{\rightleftharpoons}$

है

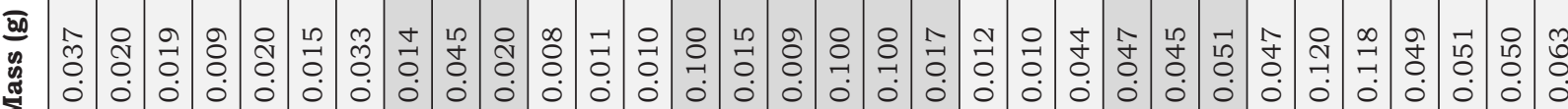
बे

$\frac{\Phi}{\mathbb{N}}$

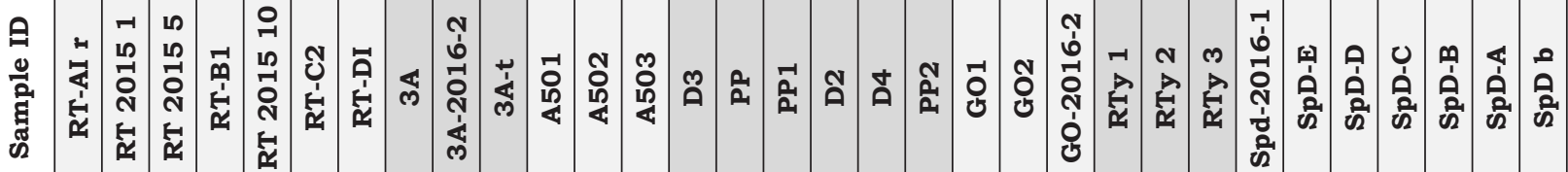

$\frac{9}{3}$

닐

要

喜

m.

$\frac{0}{\frac{0}{\circ}}$

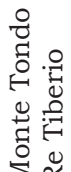

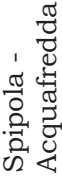




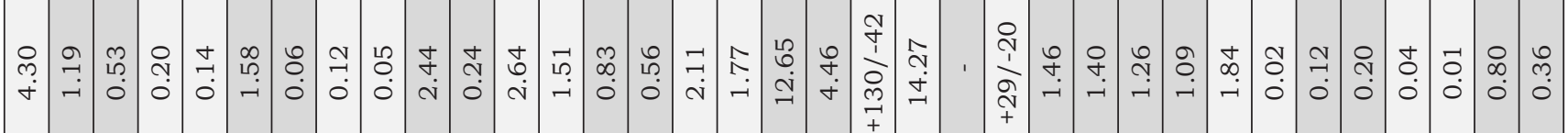

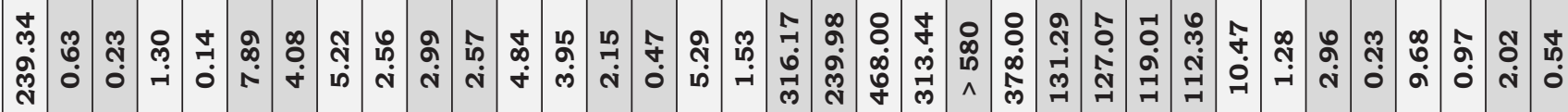

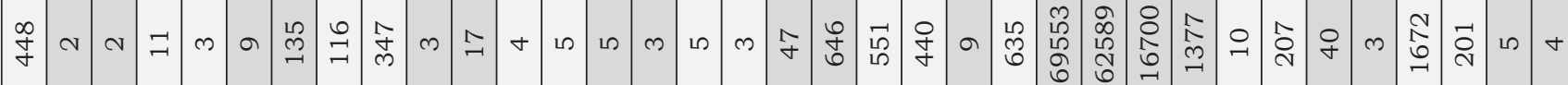

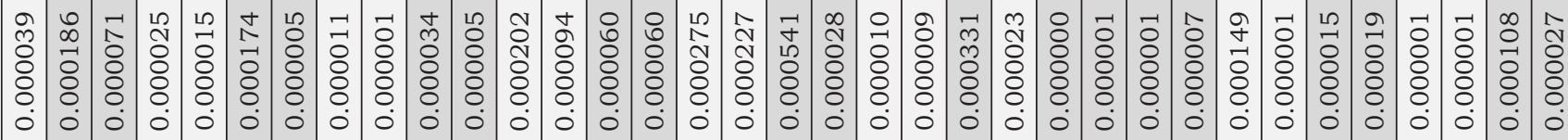

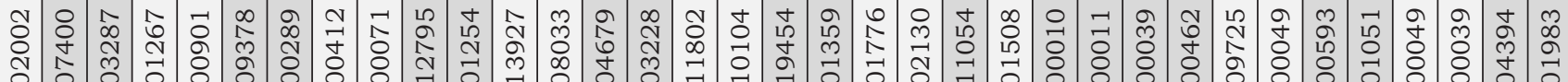

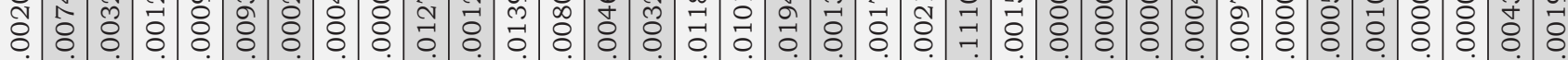

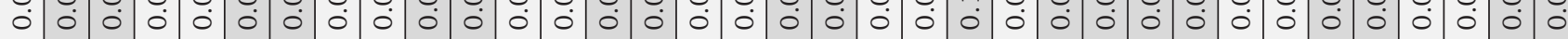

๙

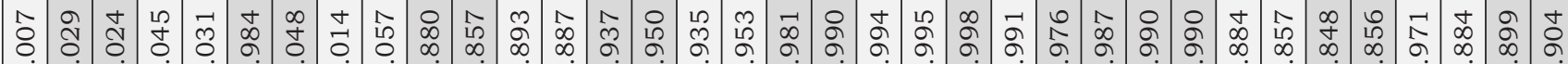

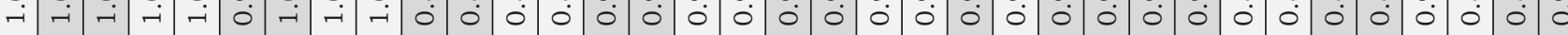

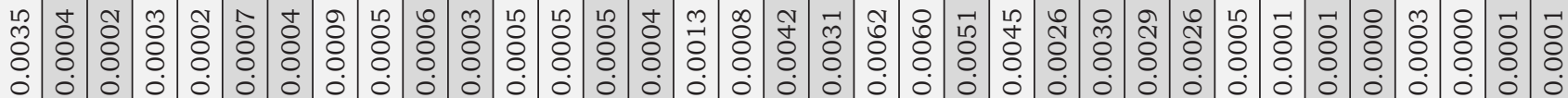

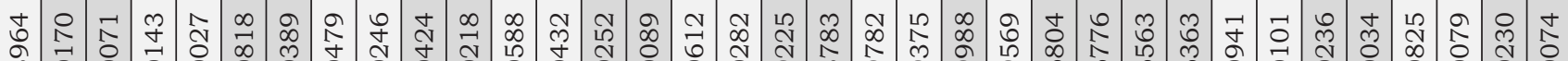

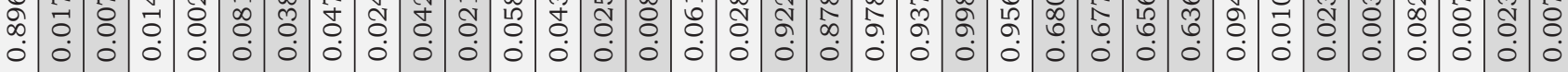

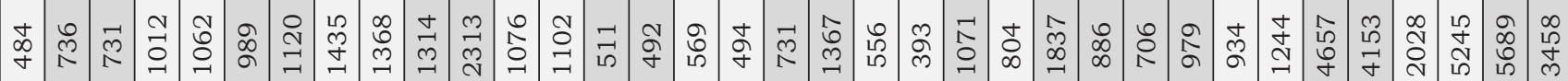

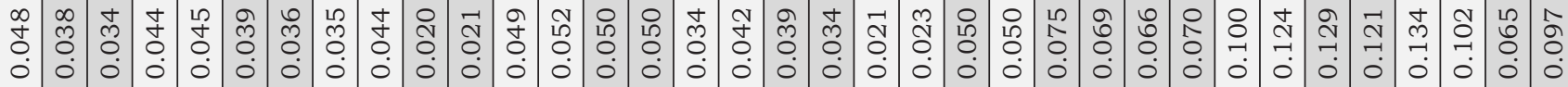

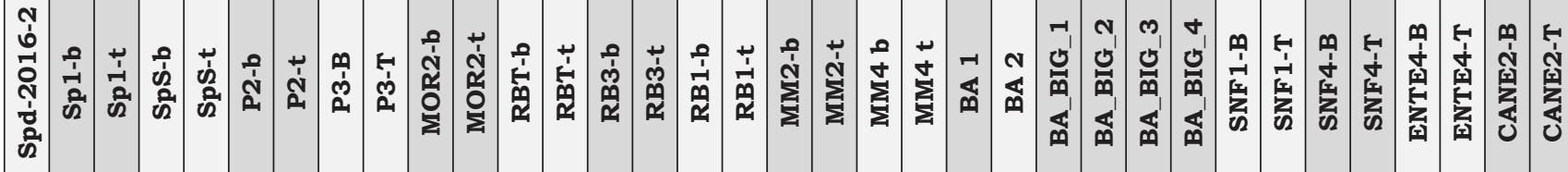

\begin{tabular}{|c|c|c|c|c|}
\hline 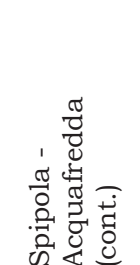 & $\begin{array}{l}0 \\
0 \\
0 \\
\Xi \\
\vdots \\
0 \\
0 \\
0 \\
0\end{array}$ & 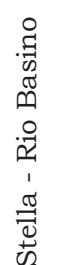 & 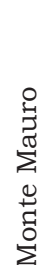 & $\begin{array}{l}\vec{D} \\
\text { : } \\
0\end{array}$ \\
\hline
\end{tabular}


When comparing the above reported radiometric ages to the LR04 $\delta^{18} \mathrm{O}$ benthic stack palaeoclimatic curve built by Lisiecki and Raymo (2005) some considerations are possible. The majority of speleothems grew during the main warm climatic pulses over the last eight interglacial-glacial cycles (Fig. 11). With the exclusion of samples reporting inaccurate or incomplete ages (i.e., MM4, $\mathrm{Ba} 1$, and $\mathrm{Ba} 2$ ), all speleothems fit with interglacial or interstadial periods. The first are phases of Holocene-like climate (NGRIP project members 2004; Martrat et al., 2007; Jouzel et al., 2007), although differences between interstadials have also been reported (Tzedakis et al., 2009), while the second are rapid comebacks to interglacial-like climate (Dansgaard et al., 1993). Moreover, speleothems were deposited during relatively wet phases. In fact, several samples are synchronous with the deposition of Mediterranean sapropels (S), according to the age scheme of Ziegler et al. (2010): RTf with S5, GO with S4, A50 and PP with S3, P2 and GO with S1 (Fig. 7). Sapropel layers have been reported in the eastern (Rossignol-Strick, 1983; Rohling, 1994) and western (Thunell et al., 1990; Emeis et al., 1991) Mediterranean Sea, and are considered symptomatic of enhanced rainfall activity around the basin (Zanchetta et al., 2007; Rohling et al., 2015). In addition, all samples grew during phases of precession minima or immediately before or after (Fig. 7). In the Northern Hemisphere, precession minima equate to summer insolation maxima (Berger $\&$ Loutre, 1991). In such circumstances, the Northern
Hemisphere monsoon is intensified, because of an increased thermal contrast between land and sea. On the other hand, no sample can be linked to stages of relative cold and dry climate.

It is also interesting to note that the life-span of individual samples is relatively short, with only SNF2, ENTE4, Ba_Big, RTf, PP, and SpD being longer than 5,000 years. Samples CANE2, SNF4, 3A, A50, P2, P3, RB1, and RB3 span between 4,000 and 1,500 years, and the others less than 1,000 years (excluding samples with problematic ages). Such brief bursts of growth are not a common feature in speleothems from limestone or dolostone caves in southern Europe. Long speleothem records (>10,000 years) of comparable warm-wet periods have been reported in nearby areas (Bard et al., 2002; Genty et al., 2003; Drysdale et al., 2005, 2007; Regattieri et al., 2014; Moseley et al., 2015), but also for recent glacial stages (Hodge et al., 2008; Moreno et al., 2010; Wainer et al., 2011, 2013). This suggests that the deterioration of the European climate does not always mark the interruption of carbonate formation in classical limestone karst. Persistent carbonate deposition has also been found on the eastern side of the Mediterranean basin (BarMatthews et al., 1999, 2003; Vaks et al., 2003; Fleitmann et al., 2009; Rowe et al., 2012).

These considerations point to carbonate speleothems from Italian gypsum caves as potential indicators of rapid warm and wet climate oscillations over the late Quaternary. Waiting for future (and more detailed)

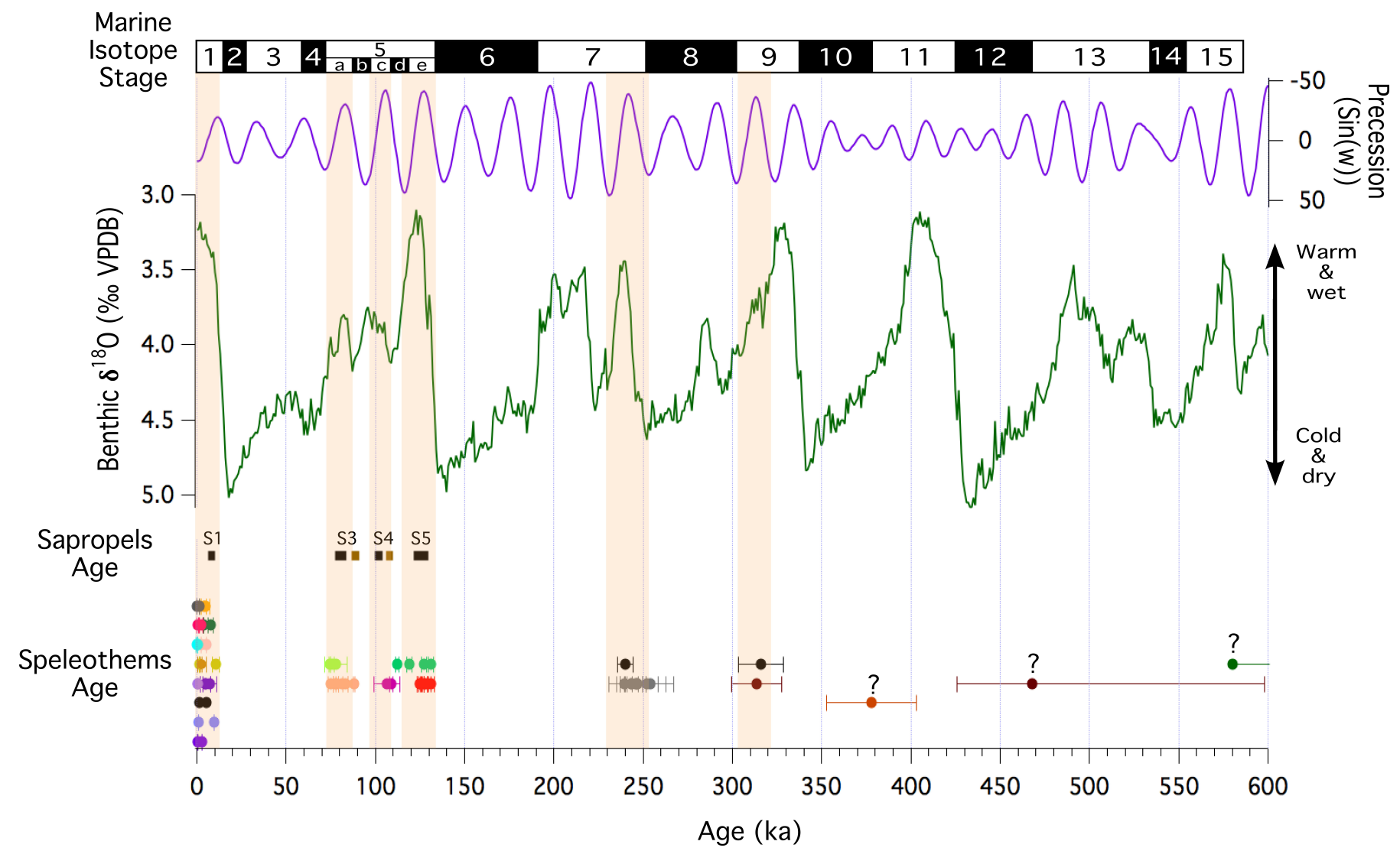

Fig. 11. Speleothem ages vs palaeoclimate variations (modified from Columbu et al., 2017). From top to bottom: marine isotopic stages alternation (black and white rectangles); variation of precession of the last 600,000 years plotted with inverted axis (Berger \& Loutre, 1991 ); LR04 $\delta^{18} \mathrm{O}$ benthic stack palaeoclimatic curve (Lisiecki \& Raymo, 2005); Sapropels age over the last 130,000 years according to Ziegler et al. (2010), with brown bars indicating sapropel precursory events; Speleothem ages and associated errors (capped horizontal lines). Speleothem life-span mostly coincides with warm and wet stages (orange bars), considering the correlation with the benthic $\delta^{18} \mathrm{O}$-curve, sapropel events and phases of precession minimum. Correlation is not attempted for speleothems reporting only one age (Ba1 and Ba2) or highly inaccurate age (MM4); these problematic samples are marked with question marks. 
studies, it seems that the deposition of carbonate speleothems in gypsum voids is only triggered when soils at the surface reach a certain threshold of $\mathrm{CO}_{2}$ content. Pedogenic $\mathrm{CO}_{2}$ is in fact the only source of carbon for these speleothems, in the cases where calcareous layers are not interbedded within the gypsum sequence. Warm and wet climates propitiate the increase of $\mathrm{CO}_{2}$ in soils, because of an increase in vegetational activity and decomposition of organic matter. However, only the numerical quantification of this threshold will shed light on the intrinsic correlation between speleothems in gypsum caves and climate, thus uncovering the strict geochemical constraints that permit $\mathrm{CaCO}_{3}$ products to be deposited in $\mathrm{CaSO}_{4}$ environments.

\section{SPELEOGENESIS AND LANDSCAPE EVOLUTION}

Gypsum karst at the surface has a very rapid development due to the high solubility of the substrate. This implies that epigenic gypsum cave systems in temperate climates are in substantial equilibrium with the local river base level, even in regions with a rapid geomorphic evolution.

Because of the fast rearrangement of caves to the local base level, relict passages testify a very rapid downcutting of the regional river network and can be used as indicators of the evolution steps of stream incision, and thus mountain uplift, in a way similar to alluvial terraces.

Due to this rapid evolution, the structure of gypsum karst systems also reflects climatic fluctuations (e.g., Columbu et al., 2015), whereas the much slower limestone endokarst evolution is mainly linked to base-level changes due to tectonic phases (e.g., Piccini, 2011; Sauro et al., 2012) or to very special conditions (e.g., the Messinian salinity crisis, Mocochain et al., 2012).

From a geomorphic and hydrogeological point of view, Italian gypsum karst mostly occurs in two different situations.

Permo-Triassic evaporites commonly are found at the bottom of valleys, where rivers have deeply incised thick Ceno-Mesozoic sedimentary successions exhuming the oldest stratigraphic units. In the Northern Apennines, Triassic evaporites usually crop out as tectonic windows, surrounded by shaly and arenaceous formations. This situation occurs, for example, in the Sassalbo area (Tuscany) (Chiesi et al., 2013) and Secchia River Valley (Emilia Romagna), where we find the deepest Italian caves in Triassic evaporites (Franchi \& Casadei, 1999). In the area of Poiano springs, halokinetic movements progressively bring the anhydrite rocks, containing halite lenses, in contact with the surface aquifer, leading to the hydration (transformation of anhydrite into gypsum) and dissolution of both halite and sulphate beds (Chiesi et al., 2010). In these areas, caves are usually formed by side tributaries of major valleys that are captured by swallow holes. Sinking caves have usually a gradient similar to that of the external slopes, whereas outflow caves have usually an almost perfectly horizontal pattern. No inactive cave levels are found, except as small relict caves along valley slopes. This happens because surface hydrography is well developed and slope erosion processes affect both evaporites and the overlying siliciclastic rocks. For this reason all the explored caves are usually related to the present hydrographic network whereas previous systems have been rapidly destroyed.

In the Apennines and in Sicily, on the contrary, Messinian "Gessoso-Solfifera" outcrops are usually shaped as long ridges or table hills, which stand out respect to the surrounding lower terrains. This happens because the Gessoso-Solfifera Formation rests on fine marine sediments and is covered by transgressive clayey formations, which are more erodible than gypsum beds. A recent uplift, still active in some sectors of the Northern and Central Apennine eastern slopes, favoured the formation of tight longitudinal, west-facing cuestas parallel to the chain axis.

The Messinian gypsum landscape has often experienced a very rapid morphological evolution that is dependent on the base level changes due to tectonic (uplift) or eustatic fluctuations, and ridges are cut by through caves with a low longitudinal gradient.

Detailed geomorphological analysis has revealed that sub-horizontal gypsum caves in the Adriatic sector of the Northern Apennines often cut across bedding planes. These cave levels formed during cold periods with stable river beds, and are coeval with fluvial terraces of rivers that flow perpendicularly to the strike of bedding in gypsum monoclines. When rivers entrench, renewed cave formation occurs very rapidly, resulting in the formation of a lower level. River aggradation caused flooding of caves and upward dissolution (paragenesis) in passages nearest to the river beds (Pasini, 2009; Columbu et al., 2015).

This evolution model is well evident in the Re Tiberio karst system (Riolo Terme, Vena del Gesso) where dating of calcite speleothems in various levels and geomorphological surveys have allowed developing a model that links speleogenesis to climate-driven river incision and aggradation (Columbu et al., 2015). Most of the dated speleothems yielded ages corresponding to relatively warm periods or stages during MIS 5 and the Holocene.

The highest cave level appears to have formed during a cold period prior to MIS 5e. The most developed and extensive cave level at $180 \mathrm{~m}$ a.s.1., almost 80 $\mathrm{m}$ above the Senio River, and the one at about 215 $\mathrm{m}$ a.s.1., both formed during cold phases in MIS 5 ( $5 \mathrm{~b}$ and $5 \mathrm{~d}$, respectively). The lower passages at 160 and $130 \mathrm{~m}$ a.s.1. probably formed during MIS 4 and MIS 2, respectively.

Apennine hillslopes during dry and cold periods were covered by a thick regolith that was available for erosion when increasing rainfall could rework these sediments down to the main channels (Simoni et al., 2013) (stages 3 and 4 in Fig. 12). These high bedload discharge periods allowed the widening of the valley by lateral erosion, carving strath terraces and aggrading terrace fills. The so-formed alluvial valley acted as a stable local base level and during 
these periods underground tributaries were able to carve horizontal gypsum cave levels. On the contrary, during warm and wet periods, widespread vegetation cover decreases the supply of hillslope sediments to the river. The channel bedrock was poorly protected during low bedload discharge periods, leading to vertical incision, entrenchment, and terrace formation (stage 1 in Fig. 12).

When the river entrenches (stage 2 of Fig. 12), the underground streams adjust themselves to the deepening base level by incising new pathways and rapidly abandoning the previous level. A renewed cooling and/or drying period brings a slowdown of entrenchment and a widening of the underground pathways (stages 3, 4, and 5 in Fig. 12).

In short, the Re Tiberio karst system well provides evidences for climate control on evolution in multilevel epigenic gypsum caves in a rapidly uplifting area. The evolution of these gypsum caves in response to base-level changes is sufficiently fast to distinguish lowering and/or aggrading events on a scale of $10^{2}$ $10^{3}$ years. Gypsum cave enlargement appears to be confined largely to cold periods, while carbonate speleothems formed during warmer and wetter climate periods due to the greater availability of $\mathrm{CO}_{2}$ (Columbu et al., 2015, 2017).

Other examples of gypsum karst systems, whose pattern reflects a rapid evolution of river network, can be found in Sicily, where sulphate evaporites form several isolated reliefs or large plateaus surrounded by impervious and easily erodible formations. As usual in gypsum karst, caves are often through flow systems that generally have origin from a swallow hole at the bottom of dolines or at the end of blind valleys. In some cases, outflow cave entrances are opened in correspondence of karst springs.

Major caves consist of a main stream passage presently in equilibrium with the elevation of the springs, with no important secondary tributaries and frequently filled by alluvial and/or breakdown deposits (Forti \& Sauro, 1996; Forti \& Rossi, 2003). Due to the higher erosion rate of the clayey formations, the river network is subject to a rapid evolution, thus these systems can consist of multiple levels of subhorizontal galleries at different elevations, connected by deep vertical shafts, testifying the alternation of stable and entrenching phases of the local base level, respectively. One of the most representative areas of this development model is that of Monte Conca (437 $\mathrm{m}$ a.s.1.), located in south-central Sicily in the Caltanissetta province, representing a typical multi-level system (Vattano, 2004, 2008; Madonia \& Vattano, 2011). In this area, gypsum outcrops show surface karst landforms and well-developed caves. Surface karst landforms consist of several types of karren, dolines, and blind valleys incised in

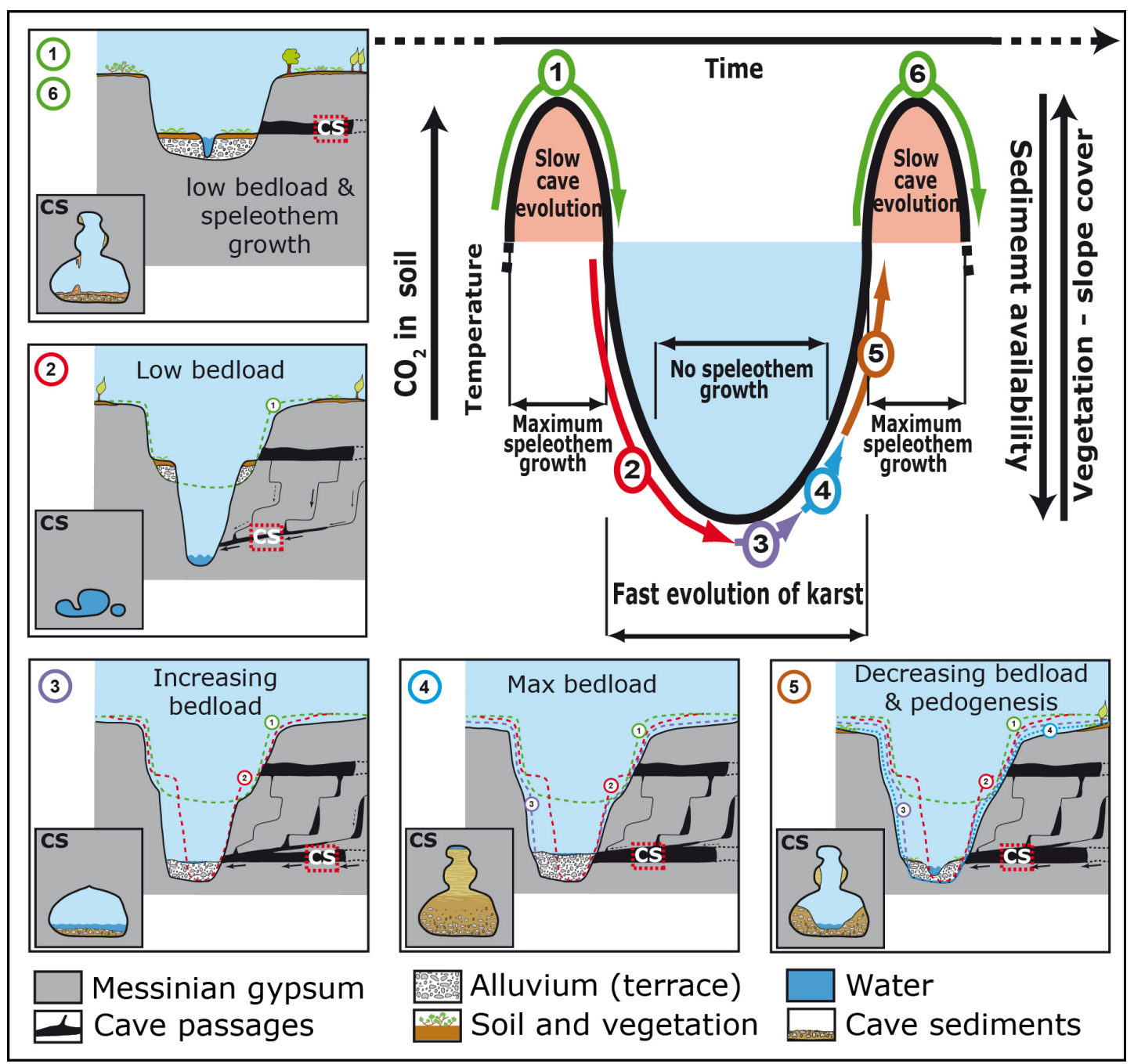

Fig. 12. Schematic evolution of epigenic gypsum caves in response to climate and local base level changes (based on Columbu et al., 2015). See text for explanation. 
non-karstifiable rocks (Forti \& Sauro, 1996; Forti \& Rossi, 2003). The geomorphological survey revealed some erosional glacis on soft rocks and planation surfaces developed between $600 \mathrm{~m}$ and $140 \mathrm{~m}$ a.s.1., which were formed during stillstand phases of the changing base level. The lowering of the local erosion base level might be linked to a general uplift trend, in agreement with geological data, that might involve the gradual emersion of this area since the early Middle Pleistocene (Vattano, 2008).

The Monte Conca karst system represents the longest and deepest gypsum karst system in Sicily, reaching about $2.5 \mathrm{~km}$ in length and about $130 \mathrm{~m}$ in depth. This system recorded in detail stillstand and lowering phases of the local erosion base level with the development of sub-horizontal galleries and vertical shafts; the underground system recorded some stillstand phases whose surface evidences have been completely erased by fluvial erosion and slope processes. Nevertheless, the upper gallery is still active, receiving water from a sinking stream, while the galleries located at intermediate elevations and some passages connected to the lower gallery are inactive even during exceptional flood events (Madonia \& Vattano, 2011).

Despite the fact that marly interlayers are present in the gypsum successions of Sicily, they do not reach a thickness and a spatial continuity enabling the development of a stepped profile under vadose conditions. Thus, the speleogenetic evolution of the Monte Conca gypsum karst system can be explained by several evolution steps always linked to successive stillstand and lowering phases of the local erosion base level, but with the interference of surface geomorphic processes that interact with its speleogenetic evolution.

In this particular case, during a first step, a system formed by intermediate galleries developed. These conduits connected the sinking points, located to the south and at a lower elevation than the actual active swallow hole, to the old spring (Paleorisorgenza). This first stage was followed by a sudden lowering of the erosion base level that caused a negative vertical shift of about $40 \mathrm{~m}$ of the spring, the subsequent fall of the base level and the deactivation of the Paleorisorgenza. In the Inghiottitoio di Monte Conca, low-gradient conduits connected the intermediate passages to the lower gallery level.

The presence of thick deposits also modified the final sector of the blind valley, which fed the karst system, causing a positive vertical shift of the swallow hole and the formation of a new sub-horizontal gallery, fed by a sinking stream, at a higher elevation. This gallery was rapidly connected with the active lower gallery through three vertical shafts.

\section{GYPSUM KARST AQUIFERS}

Most Permian-Triassic and Messinian aquifers in Italy are exposed at the surface and receive infiltration waters both from autogenic and allogenic recharge. These karst aquifers are generally of the dominant conduit drainage type (see Vigna et al., 2017) and transfer infiltrating waters rapidly underground from the recharge areas (often sinking streams and secondary tributaries coming from local inputs through dolines) to the springs. Several of these cave systems can be entirely crossed following the underground stream from the sink to the springs (i.e., Rio Stella-Rio Basino in Romagna and Grave Grubbo-Vallone Cufalo in Calabria), while in other systems the connection, although obvious, is not transitable (i.e., Monte Conca and Santa Ninfa in Sicily, Acquafredda-Spipola near Bologna). Dye tests have often allowed to know the extension of these aquifers, while physico-chemical monitoring of some springs and underground rivers have permitted to understand the hydrodynamic behaviour of the systems (Bergianti et al., 2013; Tedeschi et al., 2015). A good example of a dominant conduit drainage system is Rio Groppo, close to Reggio Emilia. This spring is fed by a series of dolines hosted in a small Messinian gypsum outcrop, with some accessible narrow caves but most of the system being unexplorable. Especially during winter, when rainfall can be intense and sometimes snow melt also contributes to the recharge, the main infiltration events cause sensible changes in flowrate, and rapid responses in terms of hydrochemistry (Fig. 13). In this case (during winter), both temperature and electrical conductivity show almost instantaneous decreases. One of the best-studied gypsum karst springs in Italy is certainly that of Poiano, in the Upper Secchia Valley (Reggio Emilia), being also the largest spring in this region (Chiesi et al., 2010). This brackish water spring drains an anhydritegypsum aquifer containing also halite lenses at depth, and its continuous monitoring has indicated this area to be slowly uplifting. Such slow tectonic movement, probably related to diapiric flow, causes the dissolution of halite bodies by the underground water flow as these penetrate into the aquifer.

In Piedmont, the Messinian gypsum beds of the Tertiary Piedmont Basin are bordered by low permeability formations (aquicludes) and are rarely encountered at the surface, being buried under a more or less thick sequence of marly and clayey sediments. Their hydrogeological study was possible in the underground gypsum quarries, especially near the villages of Moncalvo and Calliano in the Monferrato Hills (Vigna et al., 2017). These studies allowed distinguishing two different types of aquifers: systems with "interconnected conduit drainage" (i.e., Moncalvo) (Fig. 13) and with "dispersive circulation" (i.e., Calliano). The first is characterised by large phreatic conduits recharged from below (hypogenic recharge) and from slow feeding from the low permeability sediments above and below (Banzato et al., 2017). Infiltration events cause a gradual and slow increase in flowrate at the monitoring point (a spring intercepted in the underground quarry) with almost no response in both temperature and electrical conductivity. Systems with dispersive circulation, on the other hand, are hosted in an intensively fractured and karstified gypsum aquifer in which water flow is slow and homogeneous. 


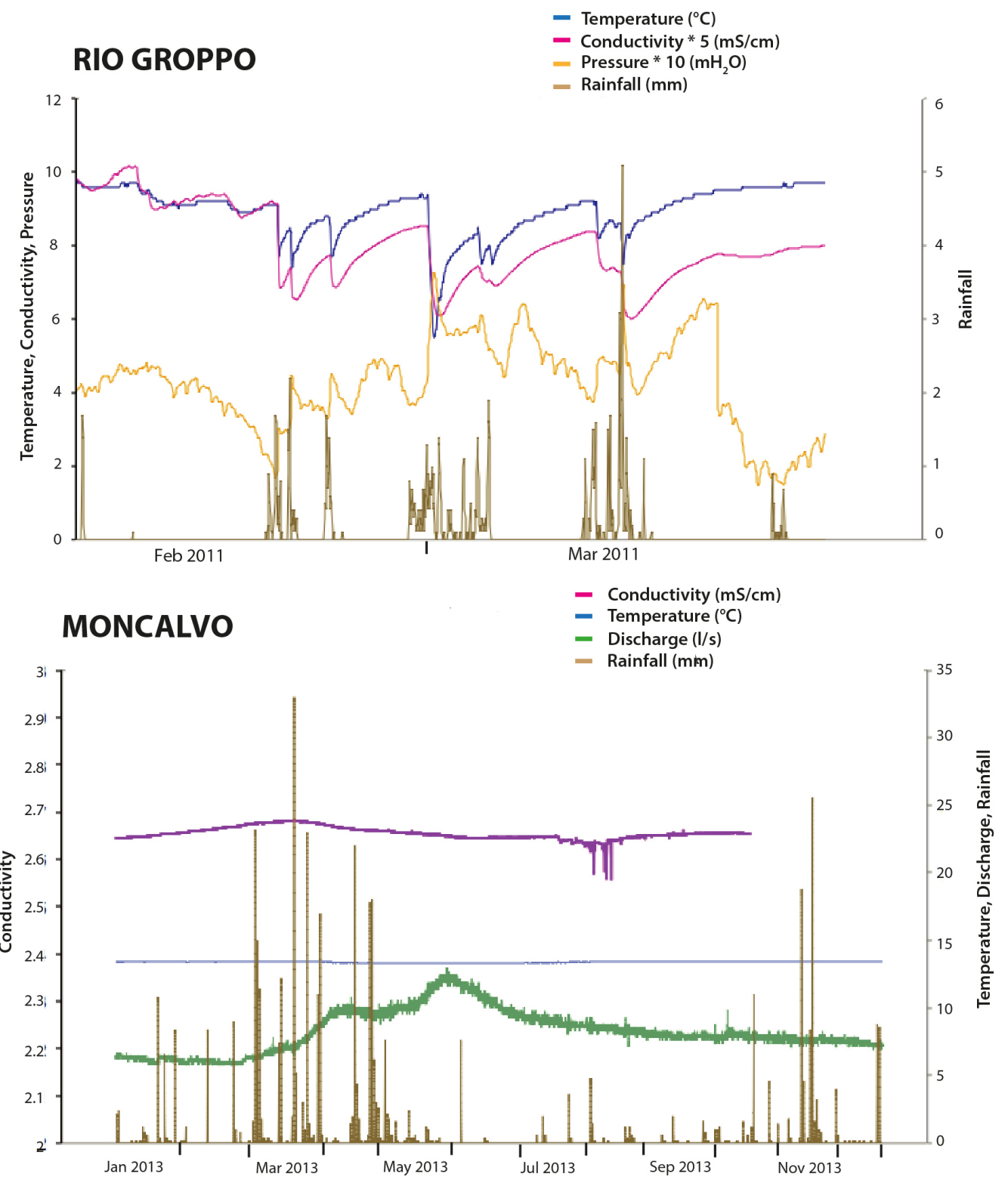

Fig. 13. Typical hydrographs of a dominant conduit drainage (Rio Groppo) and of the interconnected conduit drainage system (Moncalvo).

\section{MANAGEMENT OF EVAPORITE AREAS}

\section{Gypsum karst areas and parks}

Most of the Italian gypsum areas have been, or are still, being exploited in both underground and open pit quarries for use in the building industry (Parise, 2016). Mining started at the beginning of last century, and is now in contrast with the need for modern geological, biological and naturalistic protection and management. Since a national regulation on these quarrying activities is missing, the environmental safeguard of gypsum areas is very different from region to region (Bianco et al., 2003). Excluding the general measures of protection (i.e., parks), only two regions have promulgated specific laws for the protection of evaporite areas: Emilia-Romagna and Sicily. These are also the two regions in which scientific studies in gypsum caves are more advanced, and the local stakeholders and decision-makers have a certain environmental awareness of the importance of these areas. In the first region, almost all the gypsum outcrops have been classified as national or regional parks or protected areas, and there is no risk whatsoever of these sites being subjected to important degradation. In Sicily, on the other hand, gypsum outcrops are very extensive, and only some of them have so far been protected by special regulations ( $\mathrm{Di}$ Maggio et al., 2012) (Fig. 14).

In Sicily, in 2012 the Regional Government set up the "Sicilian protected evaporite areas network" comprising 12 Nature Reserves and 1 Natural Regional Park; some of these areas are included within two Geoparks of the European and Global Network (Panzica La Manna \& Chiaramonte, 2012). In 2015 these protected areas were recognised as Geosites under a specific regional law.

In Emilia-Romagna an extraction plan for gypsum has been defined, with only one site of quarrying (Mt. Tondo in the Vena del Gesso area) (Fig. 15A), and the remaining quarries being closed since over 40 years. Two of these old quarries have been transformed into Open Air Museums (Lucci \& Rossi, 2011), because of their importance from a palaeontological point of view: Cava a Filo on Mt. Croara, Bologna, for the discovery of Pleistocene fauna (Pasini, 1969) (Fig. 15B), and Monticino near Brisighella (Fig. 15C), 


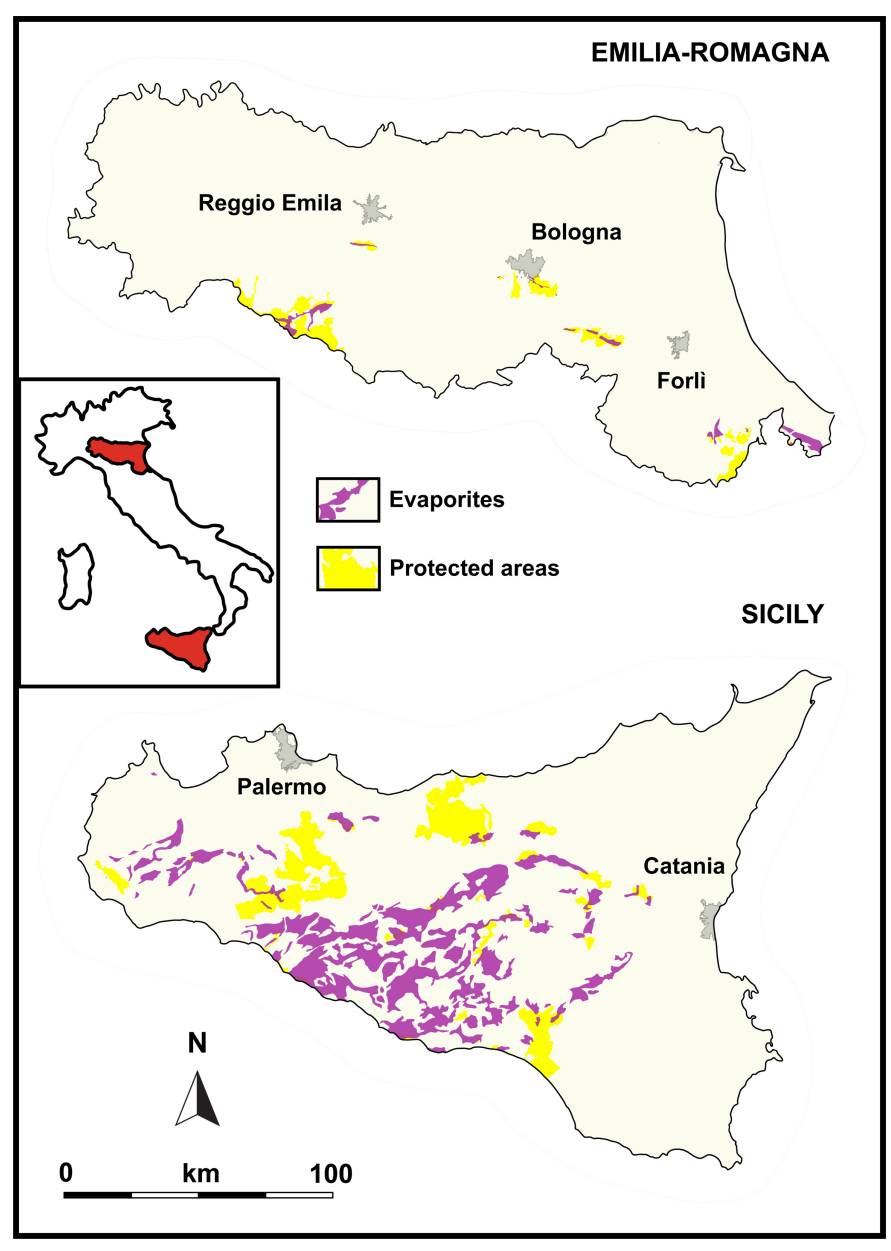

Fig. 14. Evaporite areas and their state of protecion in Emilia-Romagna and Sicily.

with a Late Messinian palaeokarst (Costa et al., 1986). Another important environmental reclamation has been carried out at the Poiano Springs, the biggest karst spring of Emilia-Romagna region. Water drains the Triassic anhydrites and gypsum in the upper Secchia Valley; the peculiar brackish environment led to the creation of a very special biotope with many endemic species of plants. Past modifications of the outflow region had entirely compromised this natural environment, which has been restored in the past few years based on old photographs and detailed studies on flora and flow regime (Chiesi et al., 2015) (Fig. $15 \mathrm{D}-\mathrm{E}$ ).

In 2016 the region Emilia-Romagna has also defined a list of karst geosites, governed by a regional law, including many of the most important cave systems and karst areas. Following this important cataloguing activity, the region has also started the preparation of a bid for the regional gypsum karst areas to become a UNESCO World Heritage site.

In both Sicily and Emilia-Romagna, the local caving groups, in agreement with the regional authorities, have also started the closure of the most important and delicate gypsum caves (over twenty caves are now locked by gates), limiting unregulated access, accidental and/or intentional damage (Fig. 15 F). Caving and other environmental associations also promote cleaning campaigns of cave entrances and dolines on a seasonal basis. There are no important show caves in gypsum in Italy, although around 15 of these are occasionally or seasonally opened to a wider public summing up to probably about 100,000150,000 visitors each year. Many of these visits are focused on schools, in the framework of raising the environmental awareness especially in the younger generations (Fig. 15G). Last, but not least, also the Friuli Venezia Giulia Region, with modest gypsum outcrops, has assigned the impressive sinkholes in the area of Sauris as geosites (Cucchi \& Finocchiaro, 2010). The FVG geosites are actually the subject of an on-going regional law aimed at their valorization and protection.

\section{Hazards in gypsum karst}

Although gypsum areas have been studied for more than a century (Madonia \& Forti, 2003, and references therein), less attention has been dedicated to natural hazards related to gypsum karst, notwithstanding the many episodes occurred throughout the country, and the effects produced on the built-up environment. Taking into account the different types of hazards linked to karst processes (Gutiérrez et al., 2014; Parise et al., 2015), sinkholes are definitely very typical for evaporite rocks, especially in consideration of the very rapid lithological dissolution/erosion $(0.70 \pm 0.17 \mathrm{~mm} / \mathrm{y})$ (Cucchi et al., 1998). In addition to the natural processes, sinkholes originated, or indirectly induced, by human activities (anthropogenic sinkholes; Parise, 2015), should also be considered. Overall, there are many sinkhole events related to evaporite bedrock, which only rarely are documented in scientific papers. In the following, we briefly summarise the main documented episodes of sinkholes linked to evaporite rocks, moving from the North to the South of Italy.

Friuli Venezia Giulia, in north-eastern Italy, has been one of the first investigated territories. The first descriptions on sinkholes in the Alta Valle del Tagliamento were already reported in the late $19^{\text {th }}$ century (Marinelli, 1897). In the 1960s, with the increasing urbanisation, the threats increased and more detailed studies started (Gortani, 1965; Berlasso et al., 1980). After preliminary technical reports describing the phenomena, in recent years an escalation in the frequency of the events has been registered, with significant damage produced on the buildings (Calligaris et al., 2010, 2017; Zini et al., 2015a, b) (Fig. 16E). Recently, extensive field surveys funded by the Regional Geological Survey of Friuli Venezia Giulia resulted in an inventory of more than 500 sinkholes linked to the Permian-Triassic mantled evaporites. Phenomena are mainly aligned in $\mathrm{E}-\mathrm{W}$ direction in correspondence of the valley floors set on the main regional thrusts crossing the whole region. Collapses and suffosion sinkholes are the prevailing typologies, with diameters ranging from half a metre to $75 \mathrm{~m}$, and depths between some decimetres and $20 \mathrm{~m}$.

In Trentino-Alto Adige the sinkhole phenomena are not common. When they occur, they have a natural origin as for the ones corresponding to small areas in the proximity of San Lugano village (Trodena municipality, in the Bolzano province). The last event happened in 2000 , when a $10 \mathrm{~m}$-wide and $15 \mathrm{~m}$-deep sinkhole was formed, following a period of intense 

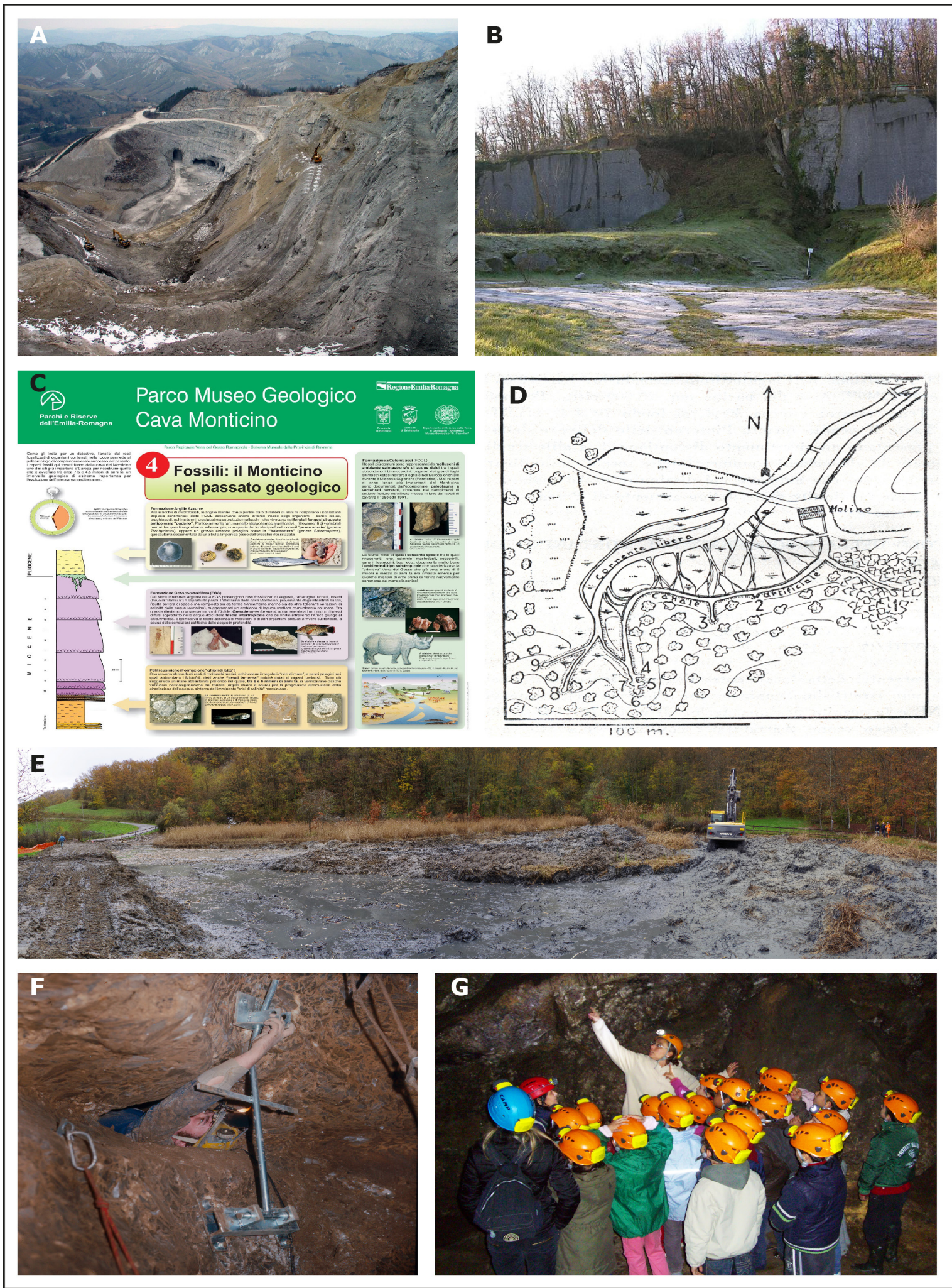

Fig. 15. Example of management of gypsum karst. A) The Monte Tondo quarry (Romagna); B) The Cava a Filo near Bologna; C) An explanatory panel in the Monticino quarry; D) Survey of the Poiano Spring area by D. Bertolani-Marchetti (1948), published in AA.VV. (1949), and E) The operations of establishment of the original natural configuration in the Poiano area; F) A gate closing one of the many gypsum caves near to Bologna; G) A cave guide with a school in Farneto Cave, near Bologna (Photos A: Piero Lucci; B-C: Jo De Waele; E: Mauro Chiesi; F: Paolo Forti; G: Regional Park Service of Gypsum at Bologna).

rainfall. Also in Trentino-Alto Adige, the known sinkholes are aligned along a NE-SW direction, which follows the tectonic structures (Nössing et al., 2004).

Moving to northwestern Italy, some examples of sinkholes in evaporite deposits were described by Alberto et al. (2008) in the Western Alps, and precisely in the Aosta Valley (Val d'Aosta), and in the Susa Valley (Piedmont). At this latter site, the phenomena were identified within a tectonic valley, where gypsum deposits are not outcropping nowadays, but a gypsum quarry was present in the past. The most striking phenomenon, $50 \mathrm{~m}$ wide and $7 \mathrm{~m}$ deep, is close to the Chiomonte village, where two other sinkholes were inventoried, too. An interesting example of anthropogenic sinkhole is in the area of 
Moncalvo (Asti province, Piedmont) where in the morning of February $15^{\text {th }}, 2005$, during excavation works in an underground gypsum quarry, a waterbearing fracture was intercepted (Vigna et al., 2010b). Overnight approximately $60,000 \mathrm{~m}^{3}$ of muds and water invaded the quarry. Meanwhile a large sinkhole (20 $\mathrm{m}$ wide and $10 \mathrm{~m}$ deep) formed at the ground, as the surface effect of the collapse of one of the main chambers of the hypogenic caves. In this case, the sinkhole was formed because the human activities encountered caves of hypogene origin, triggering a series of upward collapses that reached the ground surface (Vigna et al., 2010a). These types of situations are extremely difficult to detect from the surface, and might potentially cause extremely dangerous consequences.

In Emilia-Romagna Region, in the Upper Secchia Valley (Emilia-Romagna), during the 1950-60s, big collapse sinkholes formed in the Secchia riverbed (Fig. 16D), as documented by Colombetti \& Fazzini (1976). These phenomena reactivated again in July 2016 (Tassi, 2016), thus testifying the possibility of repeated sinkhole events at the same site, a situation that further increases the risk related to these hazards.

Other documented sinkholes occurred in EmiliaRomagna in the 1970s at Mt. Donato, close to the Gaibola church, where a bus stop suddenly collapsed, due to formation of a $20 \mathrm{~m}$ deep pit. In the same years, on the side of "Dolina della Spipola" dissolutional doline, the "Grotta delle pisoliti" cave was discovered, when a $15 \mathrm{~m}$ deep pit suddenly opened in the grassland.

In the summer 2005, in the Angelo Custode street, at the foot of Mt. Donato, a collapse occurred unroofing another cave (Grimandi \& Gaudiello, 2006) (Fig. 16C). The year after, along the same street, a collapse was formed, this time induced by leakage of the aqueduct pipes.

In Southern Italy, Apulia is one of the sectors most intensely interested by development of karst processes, due to its geological setting, and, consequently, highly affected by sinkhole phenomena (Delle Rose et al., 2004). Most of the region, however, consists of carbonate rocks, whilst the outcropping Triassic evaporite deposits are limited to a small sector of the Gargano Promontory, in Northern Apulia, at Marina di Lesina. Here, the evaporites are mantled by sand deposits of aeolian and alluvial-lacustrine origin. The gypsum deposits are intensively fractured due to tectonic stresses and the circulating waters have high values of $\mathrm{NaCl}$ due to saltwater intrusion. The combination of these two aspects accelerates the dissolution processes in the area (Fidelibus et al., 2011), where swarms of sinkholes were registered in the last 20 years, after maintenance works along a water channel connecting the Lesina Lake to the Adriatic Sea, which altered the natural hydrological conditions in the area (Parise, 2008; Fidelibus et al., 2011). Several

tens of sinkholes have been identified at Marina di Lesina, even though the precise temporal reference is available for only a dozen of the events (Parise \& Vennari, 2013) (Fig. 16A-B).

Further south, in Calabria, evaporites extensively crop out in the Verzino area (Crotone province), originating a complex network of cave system (Ferrini, 1998; Parise \& Trocino, 2005). Evolution of the caves is very rapid, marked by diffuse instabilities and rock falls, and the presence of diffuse breakdown deposits along the underground passages. At the surface, such evolution is accompanied by development of sinkholes of variable size (Iovine $\&$ Parise, 2008; Iovine et al., 2010), particularly visible in the area where the main system of Grave Grubbo - Vallone Cufalo develops. In terms of civil protection issues, the lack of premonitory signs at the ground surface before sinkhole occurrence, points out to the difficulties in the building up and operational functioning of warning systems.

In Sicily, karst phenomena are widespread and generally occur in "exposed karst" conditions, able to create well-developed surface landforms, ranging in size from microns to kilometres (Di Maggio et al., 2010). Karst features are identifiable also where evaporites are mantled by insoluble rocks. More than 100 sinkholes have been recognised and classified in the region. Among the first group, there is a number of lacustrine depressed areas in the south-western part of Sicily. They are caprock sagging sinkholes (sensu Gutiérrez et al., 2008) known as the Gorgo delle Sanguisughe, Soprano lakes, Medio and Sottano, and
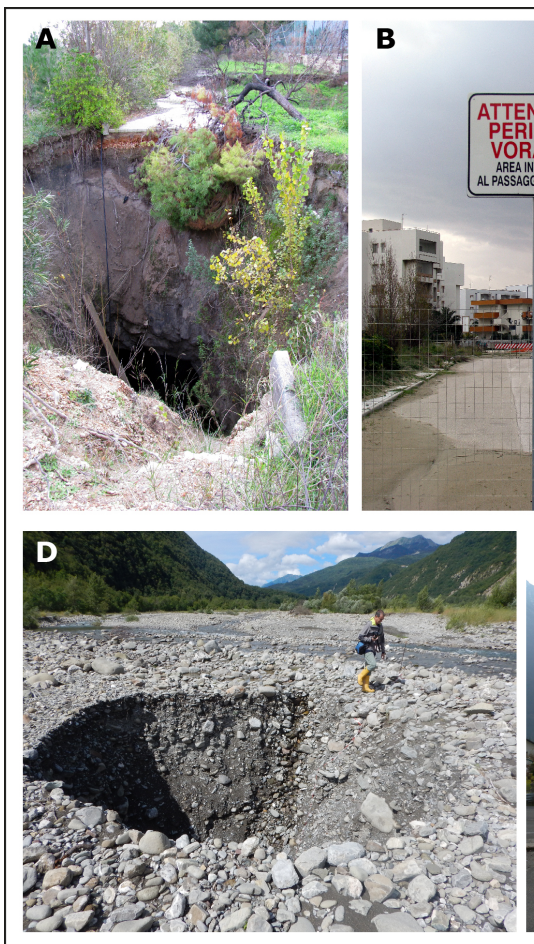

Fig. 16. Hazards in Italian gypsum areas: A) Sinkhole on Triassic gypsum at Marina di Lesina, Apulia; B) Road sign warning of the presence of sinkhole phenomena (Marina di Lesina); C) Sinkhole in the streets of Bologna, at the foot of Mt. Donato; D) Sinkhole in the alluvial bed of Secchia River, Reggio Emilia; E) The bending bell tower in the Quinis village. Its bending is due to the presence of Triassic evaporites in the subsoil mantled mainly by alluvial deposits. The entire village is heavily affected by sinkholes (the three houses on the right side of the bell tower present stability problems and the church was demolished in the 70s) (Photos A-B: Jo De Waele; C: Paolo Forti; D: William Formella; E: Luca Zini). 
Pergusa, and caprock collapse sinkholes, such as Murana, Preola lakes, Gorghi Tondi and several other depressions that, since 1998, due to their natural and environmental value, were established as Natural Reserves by Sicily region (Di Maggio et al., 2012). Cover sagging sinkholes were identified in Southern Sicily, close to the coastal area near Agrigento. They show a sub-circular shape with a diameter ranging between 120 and $300 \mathrm{~m}$, and are less than $20 \mathrm{~m}$ deep.

In Sicily, natural sinkholes and anthropogenic ones show a difference in the evolutional rate (Di Maggio et al., 2010). Sagging phenomena evolve very slowly and therefore do not constitute a risk, but may represent a natural resource of great scientific and naturalistic value.

\section{CONCLUSIONS}

Although representing only a very small part of the Italian karst terrains, gypsum karst has been studied for a long time and research on these very special areas is multidisciplinary. Gypsum outcrops are very abundant only in Sicily, but important evaporite karst areas are also known from most Italian regions, but especially from Emilia-Romagna, Calabria and Piedmont. The most detailed scientific investigations have been carried out in Emilia-Romagna, also because of the vicinity of the cave areas to densely populated territories (e.g., Bologna), but rather detailed studies were also carried out in Sicily, and to a minor extent, in Calabria, Tuscany, and Piedmont. Many of the typical surface karst features such as all sorts of karren, dolines, and even poljes, were mainly investigated in Sicily, while the knowledge on underground features including cave minerals, speleothems, and ceilingand wall sculpturing (e.g., paragenetic morphologies) mainly derives from detailed researches in caves close to Bologna. Gypsum quarries have allowed discovery of large parts of cave systems that otherwise would have remained inaccessible, enabling hydrogeological studies and a detailed knowledge on the different possible groundwater circulation systems. These accidental interceptions of cave passages also have given cavers access to phreatic, hypogene cave systems in Piedmont. On the other hand, in Romagna the discovery of multi-level cave systems and the dating of carbonate speleothems at different altitudes have brought to the development of a climate-driven speleogenetic model of epigenic gypsum caves in the northern Apennines. Further investigations also in the hotter and more arid Sicilian climate might shed light on the different speleogenesis in this area, leading to a more general Mediterranean model of gypsum cave formation.

As in other countries and regions, the gypsum rocks, being very soluble, have lead to subsidence and sinkhole phenomena in several areas, especially where anthropic activities have caused modifications in groundwater flow (e.g., Marina di Lesina, Moncalvo, Friuli Venezia Giulia).

Fortunately most gypsum karst areas are now protected by Regional or National Laws, although many areas still need adequate protection measures to be enforced, allowing to preserve these fragile geoecosystems for future researches.

\section{ACKNOWLEDGEMENTS}

This paper has been made possible thanks to the continuous interest of cavers in gypsum karst and caves, and their discoveries have enabled researchers to investigate their world in increasing detail. The caving clubs of the Federazione Speleologica Regionale dell'Emilia-Romagna, and in particular the Gruppo Speleologico Bolognese/Unione Speleologica Bolognese (GSB/USB), the Gruppo Ambientale Mezzanese (GAM), and Gruppo Speleologico Faentino are thanked for logistical and financial support. The authors thank the Sicilian cavers of the ANS Le Taddarite (Palermo), Speleo Club Ibleo (Ragusa), GS Kamicos (S. Angelo Muxaro) for the support during cave activity. The staff of the "Grotta di Santa Ninfa", "Grotta di Entella" and "Grotta di S. Angelo Muxaro" nature reserves are acknowledged for the collaboration and permissions in the protected areas. Danilo Demaria prepared the Acquafredda-Spipola Cave system drawing in Fig. 8. The map of gypsum outcrops in Italy (Fig. 1) is based on data from Fabrizio Galluzzo and Marco Pantaloni of the Geological Survey of Italy - ISPRA (Rome) and modified by Maria Luisa Garberi of the Statistical and Geographic Information Service of Emilia-Romagna Region. Historical data have been obtained from the library Centro di Documentazione Speleologica "F. Anelli" at University of Bologna. The detailed comments of three reviewers have helped improving the paper substantially.

\section{REFERENCES}

AA.VV., 1949 - Studio sulla formazione Gessoso-calcarea nell'alta valle del Secchia. Memoria Commissione Centrale del CAI, 1: 1-244.

AA.VV., 1988 - L'area carsica dell'Alta Val di Secchia: studio interdisciplinare dei caratteri ambientali. Regione Emilia-Romagna Studi e documentazioni: 42, 1-304.

Agnesi V. \& Macaluso T. (Ed.), 1989 - I Gessi di Santa Ninfa. Memorie dell'Istituto Italiano di Speleologia, 2 (3): 1-202.

Agnesi V., Macaluso T., Panzica La Manna M. \& Pipitone G., 1986 - Carta delle morfologie carsiche sulle rocce evaporitiche della Sicilia. Grotte d'Italia 13 (4): 205-213.

Alberto W., Giardino M., Martinotti G. \& Tiranti D., 2008 - Geomorphological hazards related to deep dissolution phenomena in the Western Italian Alps: distribution, assessment and interaction with human activities. Engineering Geology, 99: 147-159.

https://doi.org/10.1016/j.enggeo.2007.11.016

Aldrovandi U., 1648 - Musaeum metallicum in libros 4 distributum Bartholomaeus Ambrosinus. Bononiae, Marcus Antonius Bernia, Ferronius, 979 p.

Altara E., Demaria D., Grimandi P. \& Minarini G. (Ed.), 1995 - Atti del convegno Precursori e pionieri della Speleologia in Emilia-Romagna. Speleologia Emiliana, s. IV, 21 (6): 1-160.

Arziliero L., Baglioni A., Curtarello M., De Marco P., Rocco M., Mastellone F., Maurizio I., Schiavon E. \& Tosoni D., 2004 - Dissesti dovuti al cedimento di cavità sotterranee nel territorio della Regione del Veneto. Proceedings of the $1^{\circ}$ Seminar on Stato dell'arte sullo studio dei fenomeni di sinkholes e ruolo delle amministrazioni statali e locali nel governo del territorio, ISPRA, Roma, p. 109-119. 
Baldacci G., 1886 - Descrizione geologica dell'Isola di Sicilia. Memorie descrittive della carta geologica d'Italia, Regio Ufficio geologico, Roma, 1: 1-403.

Banzato C., Vigna B., Fiorucci A. \& De Waele J., 2017 Hypogene gypsum caves in Piedmont (N-Italy). In: Klimchouk A.B., Palmer A.N., Audra P., De Waele J. $\&$ Auler A. (Eds.), Selected hypogene karst regions and caves of the world. Cave and Karst Systems of the World book series, Springer: in press.

Bar-Matthews M., Ayalon A., Kaufman A. \& Wassenburg, J.G., 1999 - The Eastern Mediterranean paleoclimate as a reflection of regional events: Soreq cave, Israel. Earth and Planetary Science Letters, 166: 85-95. https://doi.org/10.1016/S0012-821X(98)00275-1

Bar-Matthews M., Ayalon A., Gilmour M., Matthews A. \& Hawkesworth C.J., 2003 - Sea-land oxygen isotopic relationships from planktonic foraminifera and speleothems in the Eastern Mediterranean region and their implication for paleorainfall during interglacial intervals. Geochimica et Cosmochimica Acta, 67 (17): 3181-3199.

https://doi.org/10.1016/S0016-7037(02)01031-1

Bard E., Antonioli F. \& Silenzi S., 2002 - Sea-level during the penultimate interglacial period based on a submerged stalagmite from Argentarola Cave (Italy). Earth and Planetary Science Letters, 196 (3-4): 135-146. https://doi.org/10.1016/S0012-821X(01)00600-8

Bentini L. \& Lucci P. (Ed.), 1999 - Le grotte della Vena del Gesso romagnola. I gessi di Rontana e Castelnuovo. Grafiche A\&B, Bologna: 1-135.

Berger A. \& Loutre M.F., 1991 - Insolation values for the climate of the last 10 million years. Quaternary Science Reviews, 10: 297-317.

https://doi.org/10.1016/0277-3791(91)90033-Q

Bergianti S., Capaccioni B., Dalmonte C., De Waele J., Formella W., Gentilini A., Panzeri R., Rossetti S., Sansavini G., 2013 - Progetto Life + 08 NAT/IT/000369 "GYPSUM". Primi risultati sulle analisi chimiche delle acque nei gessi dell'Emilia Romagna. In: Cucchi F. \& Guidi P. (Eds.), Atti del XXI Congresso Nazionale di Speleologia "Diffusione delle conoscenze", Trieste 2-5 giugno 2011: 296-301.

Berlasso G., Giorgetti F. \& Signanini P., 1980 - Le strutture superficiali di collasso nel territorio del Comune di Enemonzo. Rassegna Tecnica del Friuli Venezia Giulia, no. 2.

Bianco D., Panzica La Manna M. \& Sauro U., 2003 Tutela e valorizzazione delle aree carsiche italiane nelle rocce evaporitiche: problemi e prospettive. In: Madonia G. \& Forti P. (Eds.), Le aree carsiche gessose d'Italia, Istituto Italiano di Speleologia, 2 (14): 115-120.

Bottegari C., 1612 - Relazione di un viaggio all'acqua salata di Minozzo in quel di Reggio (di Modena) [Report on a journey to the salty water of Minozzo in the Reggio region (of Modena)], Documento XII in Libro di Canto e di Liuto (manuscript can be found at the Estense Library of Modena), partially reprinted In: Valdrighi LF (ed.) (1891) Il libro di Canto e Liuto di Cosimo Bottegari fiorentino, Florence.

Calaforra J.M. \& Forti P., 1999 - Le concrezioni all'interno delle grotte in gesso possono essere utilizzate come indicatori paleoclimatici? Speleologia Emiliana, 10: 10-18.

Calaforra J.M. \& Pulido-Bosch A., 1999 - Genesis and evolution of gypsum tumuli. Earth Surface Processes and Landforms, 24, 919-930.

https://doi.org/10.1002/(SICI) 1096-9837(199909) 24:10<919::AID-ESP20>3.0.CO;2-D

Calaforra J.M., Forti P. \& Fernandez-Cortes A., 2008 Speleothems in gypsum caves and their paleoclimatological significance. Environmental Geology, 53 (5): 1099-1105. https://doi.org/10.1007/s00254-007-0737-3
Calindri S., 1781 - Dizionario corografico, georgico, orittologico, storico ec. ec. ec.della Italia. Montagna e Collina del Bolognese, Vol. 2., Bologna, S. Tommaso d'Aquino: $432 \mathrm{p}$.

Calligaris C., Zini L., Cucchi F. \& Stefanelli N., 2010 Gypsum's role in the Friuli Venezia Giulia sinkholes. In: $2^{\circ}$ I sinkholes: gli sprofondamenti catastrofici nell'ambiente naturale ed in quello antropizzato. ISPRA Roma 3-4 dicembre 2009, pp. 213-221. ISBN: 978-88448-0400-8.

Calligaris C., Devoto S., Zini L. \& Cucchi F., 2015 Evaporite geo-hazard in the Sauris area (Friuli Venezia Giulia Region - Northeast Italy). In: Doctor D.H., Land L., Stephenson J.B., (Eds.), Sinkholes and the engineering and environmental impacts of karst. Proceedings of the Fourteenth Multidisciplinary Conference, October 5-9, Rochester, Minnesota: NCKRI, Symposium 5. Carlsbad, New Mexico: National Cave and Karst Research Institute, 465-470.

Calligaris C., Devoto S., Zini L. \& Cucchi F., 2017 An integrated approach for investigations of groundsubsidence phenomena in the Ovaro village (NE Italy). In: Renard P. \& Bertrand C. (Eds.) Advances in the hydrogeology of karst and carbonate reservoirs. Springer: $71-77$.

https://doi.org/10.1007/978-3-319-45465-8_8

Capellini G., 1876 - Sui terreni terziari di una parte del versante meridionale dell'Appennino. Appunti per la geologia della provincia di Bologna. Rendiconti Accademia di Scienze Ist. Bologna, 13: 587-624.

Casali R., 1972 - Idrologia ipogea della zona compresa fra $i$ torrenti Zena ed Idice in località Farneto (S. Lazzaro in Savena Bologna). Atti del VII Convegno Speleologico dell'Emilia Romagna e del Simposio di Studi sulla Grotta del Farneto, S. Lazzaro in Savena-Bologna, 9-10 Ottobre 1971. Rassegna Speleologica Italiana, Memoire X: $148-152$.

Catalano R., 1986 - Le evaporiti messiniane. Loro ruolo dell'evoluzione geologica della Sicilia (Messinian evaporites, Their role in the geologiocal evolution of Sicily). Le Grotte d'Italia, 4 (13): 109-122.

Chiesi M. (Ed.), 2001 - L'area carsica di Borzano (Albinea-Reggio Emilia). Memoria dell'Istituto Italiano di Speleologia, 2 (11): 1-158.

Chiesi M. \& Forti P. (Eds.), 2009 - Il progetto Trias: studie ricerche sulle evaporiti triassiche dell'alta Val di Secchia e sull'acquifero carsico di Poiano (The Trias Project: studies and researches on the Triassic evaporites in the Upper Secchia Valley and on the karst acquifer of Poiano springs). Memorie dell'Istituto Italiano di Speleologia, 2 (22): 1-164.

Chiesi M., Forti P. \& De Waele J., 2010 - Origin and evolution of a salty gypsum/anhydrite karst spring: the case of Poiano (Northern Apennines, Italy). Hydrogeology Journal, 18: 1111-1124.

https://doi.org/10.1007/s10040-010-0576-2

Chiesi M., De Sio F., Filippini M., Formella W., Forti P. \& Mantelli F., 2013 - L'ambiente carsico e l'idrogeologia dei gessi di Sassalbo (MS). In: Cucchi F. \& Guidi P. (Eds), Diffusione delle conoscenze. Atti del XXI Congresso Nazionale di Speleologia, Trieste, 2-5/6/2011, Edizioni Università di Trieste, 346-362.

Chiesi M., Morelli V. \& Carra G., 2015 - Il restauro ambientale dell'area di deflusso della Fontana Salsa di Poiano (Villa Minozzo, RE). In: De Nitto L., Maurano F. \& Parise M. (Eds), Atti del XXII Congresso Nazionale di Speleologia, Pertosa-Auletta (SA), 30/0502/06/2015. Memorie Istituto Italiano di Speleologia, 2 (29): 689-694. 
Ciarapica G., 1994 - Le successioni di piattaforma del Trias Superiore e del Lias Inferiore. In: Passeri L. (Ed.), L'Appenino Umbro-Marchigiano. Guide Geologiche Regionali, Società Geologica Italiana, 7: 24-27.

Ciarapica G. \& Passeri L., 1976 - Deformazioni da fluidificazione ed evoluzione diagenetica della Formazione Evaporitica di Burano. Bolletino della Società Geologica Italiana, 95: 1175-1199.

Cigna A.A. \& Burri E., 2000 - Development, management and economy of show caves. International Journal of Speleology, 29 (1-4): 1-27. https://doi.org/10.5038/1827-806X.29.1.1

Cigna A.A. \& Forti P., 1986 - The speleogenetic role of air flow caused by convection. 1st contribution. International Journal of Speleology, 15 (1-4): 41-52. https://doi.org/10.5038/1827-806X.15.1.3

Cirilli S., Pirini Radrizzani C., Ponton M. \& Radrizzani S., 1998 - Stratigraphical and palaeoenvironmental analysis of the Permian-Triassic transition in the Badia Valley (Southern Alps, Italy). Palaeogeography, Palaeoclimatology, Palaeoecology, 138: 85-113.

Colalongo M.L., Costa G.P. \& De Giuli C., 1985 - Latest Messinian vertebrate fauna preserved in a palaeokarst neptunian dyke setting. Grotte d'Italia, 4 (12): 221-235

Colombetti A. \& Fazzini P., 1976 - L'alimentazione e l'origine della sorgente salso solfata di Poiano (Reggio Emilia) : fenomeni di dissoluzione nella valle del fiume Secchia. Bollettino della Società Geologica Italiana, 95: 403-421.

Columbu A., De Waele J., Forti P., Montagna P., Picotti V., Pons-Branchu E., Hellstrom J., Bajo P. \& Drysdale R., 2015 - Gypsum caves as indicators of climate-driven river incision and aggradation in a rapidly uplifting region. Geology, 43 (6): 539-542.

https://doi.org/10.1130/G36595.1

Columbu A., Chiarini V., De Waele J., Drysdale R., Woodhead J., Hellstrom J. \& Forti P., 2017 - Late quaternary speleogenesis and landscape evolution in the northern Apennine evaporite areas. Earth Surface Processes and Landforms.

https://doi.org/10.1002/esp.4099

Costa G., Colalongo M.L., De Giuli C., Marabini S., Masini F., Torre D. \& Vai G.B., 1986 - Latest Messinian vertebrate fauna preserved in a Paleokarst-neptunian dike setting. Le Grotte d'Italia, 4 (12): 221-235.

Cozzaglio A., 1893 - I laghetti di Esine. Bollettino del Club Alpino Italiano, 26 (59): 215-228.

Cucchi F. \& Piano C., 2003 - Inquadramento geografico e geologico dei gessi in Italia. In: Madonia G. \& Forti P. (Eds.), Le aree carsiche gessose d'Italia. Memorie dell'Istituto Italiano di Speleologia, 2 (14): 17-26

Cucchi F. \& Finocchiaro F., 2010 - I geositi del Friuli Venezia Giulia. Regione Autonoma Friuli Venezia Giulia (Eds.), 383 p.

Cucchi F., Forti P. \& Finocchiaro F., 1998 - Gypsum degradation in Italy with respect to climatic textural and erosional conditions. Geografia Fisica e Dinamica Quaternaria, 3: 41-49.

Dalmonte C., Forti P. \& Piancastelli S., 2004 - The evolution of carbonate speleothems in gypsum caves as indicators of microclimatic variations: new data from the Parco dei Gessi caves (Bologna, Italy). Memorie dell'Istituto Italiano di Speleologia, 2 (16): 65-82.

Dansgaard W., Johnsen S.J., Clausen H.B., DahlJensen D., Gundestrup N.S., Hammer C.U., Hvldberg C.S., Steffensen J.P., Sveinbjornsdottir A.E., Jouzel J. \& Bond G., 1993 - Evidence for general instability of past climate from a 250-kyr ice-core record. Nature, 364: 218-220.

https://doi.org/10.1038/364218a0
De Saussure H.B., 1796 - Voyages dans les Alpes. Tome V. Neuchatel, Louis Fache-Borel: 96-99.

De Waele J. \& Pasini G., 2013 - Intra-messinian gypsum palaeokarst in the northern Apennines and its palaeogeographic implications. Terra Nova, 25: 199-205. https://doi.org/10.1111/ter.12021

Dela Pierre F., Bernardi E., Cavagna S. Clari P., Gennari R., Irace A., Lozar F., Lugli S., Manzi V., Natalicchio M., Roveri M., Violanti D., 2011 - The record of the Messinian salinity crisis in the Tertiary Piedmont Basin (NW Italy): The Alba section revisited. Palaeogeography Palaeoclimatology Palaeoecology, 310: 238-255. https://doi.org/10.1016/j.palaeo.2011.07.017

Delle Rose M., Federico A. \& Parise M., 2004 - Sinkhole genesis and evolution in Apulia, and their interrelations with the anthropogenic environment. Natural Hazards and Earth System Sciences, 4: 747-755. https://doi.org/10.5194/nhess-4-747-2004

Demaria D. Forti P., Grimandi P. \& Agolini G. (Eds.), 2012 - Le Grotte Bolognesi. Grafiche A\&B, Bologna, GSB-USB, $431 \mathrm{p}$.

Di Maggio C., Di Trapani F.P., Madonia G., Salvo D. \& Vattano M., 2010 - Primo contributo sui sinkhole nelle evaporiti della Sicilia (Italia)/First report on the sinkhole phenomena in the Sicilian evaporites (Italy). In proceedings of: 2 Workshop Internazionale. I sinkholes. Gli sprofondamenti catastrofici nell'ambiente naturale ed in quello antropizzato. Roma, 3-4 Dicembre 2009. 299-313.

Di Maggio C., Madonia G., Parise M. \& Vattano M., 2012 - Karst of Sicily and its conservation. Journal of Cave and Karst Studies, 74 (2): 157-172.

https://doi.org/10.4311/2011JCKS0209

Di Maggio C., Madonia G., Messana V., Panzica La Manna M. \& Vattano M., 2016a - Il carsismo nel rilievo gessoso di Rocca di Entella (Sicilia occidentale). Atti del Convegno Nazionale "La ricerca carsologica in Italia", 22-23 giugno 2013, Laboratorio carsologico sotterraneo di Bossea, Frabosa Soprana: 5-14.

Di Maggio C., Madonia G., Vattano M. \& De Waele J., 2016b - Genetic models of poljes in Sicily. Geophysical Research Abstracts, 18, EGU General Assembly 2016-13151.

Drysdale R.N., Zanchetta G., Hellstrom J., Fallick A.E. \& Zhao J., 2005 - Stalagmite evidence for the onset of the Last Interglacial in southern Europe at $129 \pm 1 \mathrm{ka}$. Geophysical Research Letters, 32 (24): L24708.

https://doi.org/10.1029/2005GL024658

Drysdale R.N., Zanchetta G., Hellstrom J.C., Fallick A.E., McDonald J. \& Cartwright I., 2007 - Stalagmite evidence for the precise timing of North Atlantic cold events during the early last glacial. Geology, 35 (1): 77-80.

https://doi.org/10.1130/G23161A.1

Drysdale R.N., Hellstrom J.C., Zanchetta G., Fallick A.E., Sanchez Goni M.F., Couchoud I., McDonald J., Maas R., Lohmann G. \& Isola I., 2009 - Evidence for obliquity forcing of glacial Termination II. Science, 325: 1527-1531.

https://doi.org/10.1126/science.1170371

Drysdale R.N., Paul B.T., Hellstrom J.C., Couchoud I., Greig A., Bajo P., Zanchetta G., Isola I., Spötl C., Baneschi I., Regattieri E. \& Woodhead J.D., 2012 Precise microsampling of poorly laminated speleothems for U-series dating. Quaternary Geochronology, 14: 38-47. https://doi.org/10.1016/j.quageo.2012.06.009

Emeis K.-C., Camerlenghi A., McKenzie J.A., Rio D. \& Sprovieri R., 1991 - The occurrence and significance of Pleistocene and Upper Pliocene sapropels in the Tyrrhenian Sea. Marine Geology, 100 (1): 155-182. https://doi.org/10.1016/0025-3227(91)90231-R 
Emiliani C., 1955 - Pleistocene temperatures. Journal of Geology, 63: 538-578.

https://doi.org/10.1086/626295

Ercolani M., Lucci P., Piastra S. \& Sansavini G. (Eds.), 2013 - I Gessi e la Cave i Monte Tondo. Studio multidisciplinare di un'area carsica nella Vena del Gesso Romagnola. Memorie Istituto Italiano di Speleologia, II (26): 1-559.

Ferrarese F. \& Sauro U., 2001 - Le doline: aspetti evolutivi di forme carsiche emblematiche. Le Grotte d'Italia, 2 (2): 25-38.

Ferrarese F., Macaluso T., Madonia G., Palmeri A. \& Sauro U., 2002 - Solution and recrystallization processes and associated landforms in gypsum outcrops of Sicily. Geomorphology, 49 (1-2): 25-43.

https://doi.org/10.1016/S0169-555X(02)00159-9

Ferrini G. (Ed.), 1998 - I gessi di Verzino (kr): l'Area carsica delle vigne di Verzino. Istituto Memorie dell'Istituto Italiano di Speleologia, 2 (10): 1-128.

Fidelibus M.D., Gutiérrez F. \& Spilotro G., 2011 - Humaninduced hydrogeological changes and sinkholes in the coastal gypsum karst of Lesina Marina area (Foggia Province, Italy). Engineering Geology, 118 (1-2): 1-19. https://doi.org/10.1016/j.enggeo.2010.12.003

Fioraso G., Bicchi E., Irace A \& Boano P., 2004 Manifestazioni carsiche nelle evaporiti messiniane del Monferrato e della Collina di Torino (Italia nordoccidentale): analisi dei meccanismi genetici nel quadro dell'evoluzione pliocenico-quaternaria del Bacino Terziario Piemontese. Il Quaternario. Italian Journal of Quaternary Sciences, 17 (2/2): 453-476.

Fleitmann D., Cheng H., Badertscher S., Edwards R.L., Mudelsee M., Göktürk O., Fankhauser A., Pickering R., Raible C. \& Matter A., 2009 - Timing and climatic impact of Greenland interstadials recorded in stalagmites from northern Turkey. Geophysical Research Letters, 36 (19): L19707.

https://doi.org/10.1029/2009GL040050

Ford D.C. \& Williams P.W., 2007 - Karst hydrogeology and geomorphology. Chichester, John Wiley and Sons, 562 p. https://doi.org/10.1002/9781118684986

Forti P., 1996 - Erosion rate, crystal size and exokarst microforms. In Ginès A., Knez M., Slabe T., Dreybrodt W. (Eds.), Karst Rock Features - Karren sculpturing, Zalozba Zrc, Zrc Sazu, Ljubljana, p. 261-276.

Forti P., 1997 - Speleothems in gypsum caves. International Journal of Speleology, 25 (3-4): 91-104. https://doi.org/10.5038/1827-806X.25.3.7

Forti P. (Ed.), 2004 - Gypsum Karst Areas in the World: their protection and tourist development. Memorie dell'Istituto Italiano di Speleologia, 2 (16): 1-168.

Forti P., 2017 - Chemical deposits in evaporite caves: an overview. International Journal of Speleology, 46 (2): 109-135.

https://doi.org/10.5038/1827-806X.46.2.2063

Forti P. \& Francavilla F., 1990 - Gli acquiferi carsici dell'Emilia-Romagna: conoscenze attuali e problemi di salvaguardia. Ateneo Parmense, Acta Naturalia, 26 (1-2): 69-80.

Forti P. \& Grimandi P. (Ed.), 1986 - Atti del simposio Internazionale sul carsismo nelle evaporiti. Le Grotte d'Italia, 4 (12): 1-420.

Forti P. \& Lucci P. (Eds.), 2010 - Il Progetto Stella-Basino. Studio multidisciplinare di un sistema carsico nella Vena del Gesso Romagnola. Memorie Istituto Italiano di Speleologia, II (14): 260 p.

Forti P. \& Postpischl D., 1980 - Derivazione di dati neotettonici da analisi di concrezioni alabastrine: II contributo. Contributi preliminari alla realizzazione della Carta neotettonica d'Italia, 356: 1399-1409.
Forti P. \& Rabbi E., 1981 - The role of $\mathrm{CO}_{2}$ in gypsum speleogenesis: $I^{\circ}$ contribution. International Journal of Speleology, 11: 207-218. https://doi.org/10.5038/1827-806X.11.3.3

Forti P. \& Sauro U., 1996 - The gypsum karst of Italy. International Journal of Speleology, 25 (3-4): 239-250. https://doi.org/10.5038/1827-806X.25.3.18

Forti P., Francavilla F., Prata E., Rabbi E., Veneri P. \& Finotelli F., 1985 - Evoluzione idrogeologica dei sistemi carsici dell'Emilia-Romagna: 1- Problematica generale; 2- Il complesso Spipola - Acqua Fredda. Regione Emilia Romagna, Tip. Moderna, Bologna, 1-60.

Forti P., Agnesi V., Macaluso T. \& Panzica La Manna M. (Ed.), 1987 - Atti del Simposio Internazionale sul carsismo nelle evaporiti: il carsismo delle evaporiti in Sicilia. Le Grotte d'Italia, 4 (13): 1-213.

Forti P., Francavilla F., Prata E., Rabbi E. \& Griffoni A., 1989 - Evoluzione idrogeologica dei sistemi carsici dell'Emilia-Romagna: il complesso Rio Stella-Rio Basino (Riolo Terme, Italia). Atti XV Congresso Nazionale di Speleologia: 349-368.

Franchi M. \& Casadei A., 1999 - Il sistema carsico di Monte Caldina. Alta Valle del Fiume Secchia, Reggio Emilia. Atti XII Convegno Speleologico Regionale dell'Emilia Romagna. Casola Valsenio 30 October 1999, Speleologia Emiliana, 10: 19-27.

Gandin A., Giamello M., Guasparri G., Mugnaini S. \& Sabatini G., 2000 - The Calcare Cavernoso of the Montagnola Senese (Siena, Italy): mineralogicalpetrographic and petrogenetic features. Mineralogica et Petrographica Acta, 43: 271-289.

Gemmellaro M., 1850 - Sul preteso vulcano di Montegrande presso Pietraperzia. Accademia Goenia di Scienze Naturali Catania, 2 (7): 143-154.

Gemellaro M., 1915 - Le doline della formazione gessosa a N-E di Santa Ninfa (Trapani). Giornale di Scienze Naturali ed economiche, 41: 1-49.

Genty D., Blamart D., Ouahdi R., Gilmour M., Baker A., Jouzel J. \& Sandra V.E., 2003 - Precise dating of Dansgaard-Oeschger climate oscillations in western Europe from stalagmite data. Nature, 421: 833-837.

Gortani M., 1965 - Le doline alluvionali. Natura e Montagna, V (3): 120-128.

Grimandi P. \& Gaudiello F., 2006 - Il Pozzo di Monte Donato. Sottoterra, 123: 24-29.

Gutiérrez F., Guerrero J. \& Lucha P., 2008 - A genetic classification of sinkholes illustrated from evaporite paleokarst exposures in Spain. Environmental Geology, 53: 993-1006.

https://doi.org/10.1007/s00254-007-0727-5

Gutiérrez F., Parise M., De Waele J. \& Jourde H., 2014 A review on natural and human-induced geohazards and impacts in karst. Earth-Science Reviews, 138: 61-88. https://doi.org/10.1016/j.earscirev.2014.08.002

Hauser S., Cusimano G. \& Vassallo M., 2002 Idrogeochimica di ambienti umidi costieri: Mazara del Vallo, Trapani. GEAM, Rivista dell'Associazione georisorse e ambiente, 4: 71-76.

Hellstrom J., 2003 - Rapid and accurate U/Th dating using parallel ion-counting multi-collector ICP-MS. Journal of Analytical Atomic Spectrometry, 18: 1346-1351.

https://doi.org/10.1039/b308781f

Hellstrom J., 2006 - U-Th dating of speleothems with high initial ${ }^{230}$ Th using stratigraphical constraint. Quaternary Geochronology, 1 (4): 289-295. https://doi.org/10.1016/j.quageo.2007.01.004

Henderson G.M., 2006 - Climate. Caving in to new chronologies. Science, 313: 620-622.

https://doi.org/10.1126/science. 1128980 
Hill C.A. \& Forti P., 1997 - Cave minerals of the world. National Speleological Society, Huntsville.

Hodge E.J., Richards D.A., Smart P.L., Andreo B., Hoffmann D.L., Mattey D.P. \& González-Ramón A., 2008 - Effective precipitation in southern Spain $(266$ to $46 \mathrm{ka}$ ) based on a speleothem stable carbon isotope record. Quaternary Research, 69 (3): 447-457. https://doi.org/10.1016/j.yqres.2008.02.013

Hsü K. J., Montadert L., Bernoulli D., Cita M.B., Erickson A. \& Garrison R.E., Kidd R.B., Mélieres F., Müller C. \& Wright R., 1977 - History of the Mediterranean salinity crisis. Nature, 267: 399-403. https://doi.org/10.1038/267399a0

Iovine G. \& Parise M., 2008 - I sinkholes in Calabria. Memorie Descrittive della Carta Geologica d'Italia, 85: 335-386.

Iovine G., Parise M. \& Trocino A., 2010 - Instability phenomena in the evaporite karst of Calabria, Southern Italy. Zeitschrift fur Geomorphologie, 54 (2): 153-178. https://doi.org/10.1127/0372-8854/2010/0054S2-0009

Jouzel J., Masson-Delmotte V., Cattani O., Dreyfus G., Falourd S., Hoffmann G., Minster B., Nouet J., Barnola J.M., Chappellaz J., Fischer H., Gallet J.C., Johnsen S., Leuenberger M., Loulergue L., Luethi D., Oerter H., Parrenin F., Raisbeck G., Raynaud D., Schilt A., Schwander J., Selmo E., Souchez, R., Spahni R., Stauffer B., Steffensen J.P., Stenni B., Stocker T.F., Tison J.L., Werner M. \& Wolff E.W., 2007 - Orbital and millennial Antarctic climate variability over the past 800,000 years. Science, 317: 793-796.

https://doi.org/10.1126/science. 1141038

Klimchouk A.B., 2007. Hypogene speleogenesis: hydrogeological and morphogenetic perspective. National Cave and Karst Research Institute, Carlsbad, 106 p.

Klimchouk A.B., 2009. Morphogenesis of hypogenic caves. Geomorphology, 106: 100-117.

https://doi.org/10.1016/j.geomorph.2008.09.013

Klimchouk A., Lowe D., Cooper A. \& Sauro U. (Eds.), 1996 - Gypsum karst of the world. International Journal of Speleology, 25 (3): 1-309.

http://scholarcommons.usf.edu/ijs/vol25/iss3/

Laghi T., 1806 - Di un nuovo sale fossile scoperto nel Bolognese. Memorie Istituto Nazionale Italiano, T. 1, parte prima: 207-218.

Liguori V., Manno G. \& Mortellaro D., 2008 - Evaporite karst in Sicily. Environmental Geology, 53 (5): 975-980. https://doi.org/10.1007/s00254-007-0723-9

Lisiecki L.E. \& Raymo M.E., 2005 - A Pliocene-Pleistocene stack of 57 globally distributed benthic $\delta^{18} \mathrm{O}$ records. Paleoceanography, 20 (1): 1-17.

Lucci P. \& Piastra S. (Eds.), 2015 - I Gessi di Brisighella e Rontana: studio multidisciplinare di un'area carsica nella Vena del Gesso Romagnola. Memorie Istituto Italiano di Speleologia, II (28): 1-751.

Lucci P. \& Rossi A. 2011 - Speleologia e geositi carsici in Emilia-Romagna. Pendragon, Bologna.

Lugli S., 2001 - Timing of post-depositional events in the Burano Formation of the Secchia valley (Upper Triassic, Northern Apennines), clues from gypsum \pm anhydrite transitions and carbonate metasomatism. Sedimentary Geology, 140: 107-122. https://doi.org/10.1016/S0037-0738(00)00174-3

Lugli S., Manzi V., Roveri M. \& Scheiber B.C., 2010 - The Primary Lower Gypsum in the Mediterranean: a new facies interpretation for the first stage of the Messinian salinity crisis. Palaeogeography, Palaeoclimatology, Palaeoecology, 297 (1): 83-99.

https://doi.org/10.1016/j.palaeo.2010.07.017
Macaluso T. \& Sauro U., 1996a - The Karren in evaporite rocks: a proposal of classification. In Fornos J.J. \& Gines, A. (Eds.), Karren landforms, Universitat de les Illes Balears, p. 277-293.

Macaluso T. \& Sauro U, 1996b - Weathering crust and karren on exposed gypsum surfaces. International Journal of Speleology, 25 (3-4): 115-126.

https://doi.org/10.5038/1827-806X.25.3.9

Macaluso T. \& Sauro U., 1998 - Aspects of weathering and landforms evolution on gypsum slopes and ridges of Sicily. Supplements of Geografia Fisica e Dinamica Quaternaria, 3 (4): 91-99.

Macaluso T., Madonia G., Palmeri A. \& Sauro U., 2001 Atlante dei karren nelle evaporiti della Sicilia. Quaderni del Museo Geologico "G.G. Gemmellaro", 5: 1-143.

Madonia G. \& Forti P., 2003 - Le aree carsiche gessose d'Italia. Memorie Istituto Italiano di Speleologia, II (14), $285 \mathrm{p}$.

Madonia G. \& Sauro U., 2009 - The karren landscapes in the evaporitic rocks of Sicily. In: Ginès, A., Knez, M., Slabe, T. \& Dreybrodt, W. (Eds.), Karst rock features Karren sculpturing. Karst Research Institute ZRC SAZU, Postojna/ Ljubljana, Carsologica, 9: 525-533.

Madonia G. \& Vattano M., 2011 - New knowledge on the Monte Conca gypsum karst system (central-western Sicily, Italy). Acta Carsologica, 40 (1): 53-64.

https://doi.org/10.3986/ac.v40i1.28

Madonia G., Panzica La Manna M. \& Vattano M., 2016 - Trent'anni di ricerche carsologiche nelle evaporiti della Sicilia. Atti del Convegno Nazionale "La ricerca carsologica in Italia", 22-23 giugno 2013, Laboratorio carsologico sotterraneo di Bossea, Frabosa Soprana: 37-48.

Manzi V., Lugli S., Roveri M. \& Schreiber B.C., 2009 - A new facies model for the Upper Gypsum of Sicily (Italy): chronological and palaeoenvironmental constraints for the Messinian salinity crisis in the Mediterranean. Sedimentology, 56: 1937-1960.

https://doi.org/10.1111/j.1365-3091.2009.01063.x

Marinelli O. 1897 - Fenomeni di tipo carsico nei terrazzi alluvionali della Valle del Tagliamento. Memorie Società Geografica Italiana, 2: 415-419.

Marinelli O., 1899 - Fenomeni analoghi a quelli carsici nei gessi della Sicilia. Atti del III Congresso Geografico Italiano, Firenze: 1-14.

Marinelli O., 1910 - Fenomeni carsici nei gessi dei dintorni di Calatafimi. Mondo Sotterraneo, 7 (1-2): 16-20.

Marinelli O., 1911 - Per lo studio delle grotte e dei fenomeni carsici della Sicilia. Atti del VII Congresso Geografico Italiano, Palermo: 1-21.

Marinelli O., 1917 - Fenomeni carsici nelle regioni gessose d'Italia. Memorie Geografiche di Giotto Dainelli, supplement to Rivista Geografica Italiana, 34: 263-416

Marsili L.F., 1698 - Scritti inediti di L.F. Marsili raccolti e pubblicati nel II Centenario della morte. a cura del Comitato marsiliano, Bologna, Zanichelli, 1930.

Martini R., Gandin A. \& Zaninetti L., 1989 - Sedimentology, stratigraphy and micropaleontology of the triassic evaporitic sequence in the subsurface of Boccheggiano and in some outcrops of southern Tuscany (Italy). Rivista Italiana di Paleontologia e Stratigrafia, 95 (1): 3-28.

Martinis B. \& Pieri M., 1964 - Alcune notizie sulla formazione evaporitica del Triassico Superiore nell'Italia centrale e meridionale. Memorie della Società Geologica Italiana, 4 (1): 649-678.

Martrat B., Grimalt J.O., Shackleton N.J., de Abreu L., Hutterli M.A. \& Stocker T.F., 2007 - Four climate cycles of recurring deep and surface water destabilizations on the Iberian margin. Science, 317: 502-507. https://doi.org/10.1126/science.1139994 
Meneghel M., 1998 - Morfologia epigea. In: Ferrini G. (Ed.), 1998 - I gessi di Verzino (kr): l'Area carsica delle Vigne di Verzino. Memorie dell'Istituto Italiano di Speleologia, 10 (2): 29-34.

Merino A., Ginés J., Tuccimei P., Soligo M. \& Fornós J., 2014 - Speleothems in Cova des Pas de Vallgornera: their distribution and characteristics within an extensive coastal cave from the eogenetic karst of southern Mallorca (Western Mediterranean). International Journal of Speleology, 43 (2): 125-142. https://doi.org/10.5038/1827-806X.43.2.3

Mocochain L., Audra P., \& Bigot J.Y., 2011 - Base level rise and per ascensum model of speleogenesis (PAMS). Interpretation of deep phreatic karsts, vauclusian springs and chimney-shafts. Bulletin de la Société géologique de France, 182 (2): 87-93.

https://doi.org/10.2113/gssgfbull.182.2.87

Moreno A., Stoll H.M., Jimenez-Sanchez M., Cacho I., Valero-Garces B., Ito E. \& Edwards R.L., 2010 - A speleothem record of glacial (25-11.6 kyr BP) rapid climatic changes from northern Iberian Peninsula. Global and Planetary Change, 71: 218-231. https://doi.org/10.1016/i.gloplacha.2009.10.002

Mornig G., 1935 - Grotte di Romagna: dodici mesi di esplorazioni speleologiche nel brisighellese 1934-1935. Unpublished report, included in Memorie di Speleologia Emiliana (1995), 1: 1-32.

Moseley G.E., Spötl C., Cheng H., Boch R., Min A. \& Edwards R.L., 2015 - Termination-II interstadial/ stadial climate change recorded in two stalagmites from the north European Alps. Quaternary Science Reviews, 127: 229-239.

https://doi.org/10.1016/j.quascirev.2015.07.012

NGRIP North Greenland Ice Core Project Members, 2004 - High-resolution record of Northern Hemisphere climate extending into the last interglacial period. Nature, 431: 147-151. https://doi.org/10.1038/nature02805

Nössing L., Strada C., Nobile M., Gradizzi A., 2004 Indagini geognostiche finalizzate al riconoscimento della pericolosità dei sinkhole di passo San Lugano (BZ) nei gessi del Bellerophon. Report interno. Servizio Geologico della Provincia Autonoma di Bolzano.

Panzica La Manna M. \& Chiaramonte F., 2012 - The protected evaporite areas network of Sicily. Proceedings of the $11^{\text {th }}$ European Geoparks Conference, 19-21 September 2012, Arouca (P).

Parise M., 2008 - I sinkholes in Puglia. Memorie Descrittive della Carta Geologica d'Italia, 85: 309-334.

Parise M., 2015 - Karst geo-hazards: causal factors and management issues. Acta Carsologica, 44 (3): 401-414.

Parise M., 2016 - Modern resource use and its impact in karst areas - mining and quarrying. Zeitschrift für Geomorphologie (Supplement 10), 60: 199-216. https://doi.org/10.1127/zfg_suppl/2016/00312

Parise M. \& Trocino A., 2005 - Gypsum karst in the Crotone province (Calabria, southern Italy). Acta Carsologica, 34 (2): 369-382.

Parise M. \& Vennari C., 2013 - A chronological catalogue of sinkholes in Italy: the first step toward a real evaluation of the sinkhole hazard. In: Land L., Doctor D.H. \& Stephenson B. (Eds.), Proceedings of the $13^{\text {th }}$ Multidisciplinary Conference on Sinkholes and the Engineering and Environmental Impacts of Karst, Carlsbad (New Mexico, USA), 6-10 May 2013, National Cave and Karst Research Institute: 383-392.

Parise M., Ravbar N., Živanovic V., Mikszewski A., Kresic N., Mádl-Szo Szőnyi J. \& Kukuric N., 2015 - Hazards in Karst and Managing Water Resources Quality. In: Stevanovic Z. (Ed.), Karst Aquifers - Characterization and Engineering. Professional Practice in Earth Sciences, Springer: 601-687.

https://doi.org/10.1007/978-3-319-12850-4 17
Pasini G., 1967a - Osservazioni sui canali di volta delle grotte bolognesi. Le Grotte d'Italia, 4 (1): 17-74.

Pasini G., 1967b-Nota preliminare sul ruolo speleogenetico dell'erosione "antigravitativa". Le Grotte d'Italia, 4 (1): 75-90.

Pasini G., 1969 - Fauna a mammiferi del Pleistocene superiore in un paleo-inghiottitoio carsico presso Monte Croara (Bologna). Le Grotte d'Italia, 4 (2): 1-46.

Pasini G., 1970 - Contributo alla conoscenza del tardo Wurmiano e del Postwurmiano nei dintorni di Bologna (Italia). Giornale di Geologia, 36 (2): 687-700.

Pasini G., 1975 - Sull'importanza speleogenetica dell' "Erosione antigravitativa". Grotte d'Italia, 4 (4): 297-322.

Pasini G., 2009 - A terminological matter: paragenesis, antigravitative erosion or antigravitational erosion? International Journal of Speleology, 38 (2): 129-138. https://doi.org/10.5038/1827-806X.38.2.4

Pasini G., 2012 - Speleogenesis of the "Buco dei Vinchi" inactive swallow hole (Monte Croara karst sub-area, Bologna, Italy), an outstanding example of antigravitative erosion (or "paragenesis") in selenitic gypsum. An outline of the "post-antigravitative erosion". Acta Carsologica, 41 (1): 15-34.

Passeri L., 1975 - L'ambiente deposizionale della formazione evaporitica nel quadro della paleogeografia del Norico tosco-umbro-marchigiano. Bolletino della Società Geologica Italiana, 94: 231-268.

Piccini L., 2003 - Toscana. In: Madonia G. \& Forti P. (Eds.), Le aree carsiche gessose d'Italia. Memorie dell'Istituto Italiano di Speleologia, 2 (14): 185-196.

Piccini L., 2011 - Speleogenesis in highly geodynamic contexts: the quaternary evolution of Monte Corchia multilevel karst system (Alpi Apuane, Italy). Geomorphology, 134: 49-61.

https://doi.org/10.1016/j.geomorph.2011.06.005

Regattieri E., Zanchetta G., Drysdale R.N., Isola I., Hellstrom J.C. \& Roncioni A., 2014 - A continuous stable isotope record from the penultimate glacial maximum to the Last Interglacial (159-121ka) from Tana Che Urla Cave (Apuan Alps, central Italy). Quaternary Research, 82 (2): 450-461.

https://doi.org/10.1016/j.yqres.2014.05.005

Richards D.A. \& Dorale J.A., 2003 - Uranium-series chronology and environmental applications of speleothems. Reviews in Mineralogy and Geochemistry, 52 (1): 407-460.

https://doi.org/10.2113/0520407

Rohling E.J., 1994 - Review and new aspects concerning the formation of eastern Mediterranean sapropels. Marine Geology, 122: 1-28. https://doi.org/10.1016/0025-3227(94)90202-X

Rohling E.J., Marino G. \& Grant K.M., 2015 Mediterranean climate and oceanography, and the periodic development of anoxic events (sapropels). Earth-Science Reviews, 143: 62-97. https://doi.org/10.1016/j.earscirev.2015.01.008

Rossignol-Strick M., 1983 - African monsoons, an immediate climate response to orbital insolation. Nature, 304: 46-49.

https://doi.org/10.1038/304046a0

Roveri M., Bassetti M.A. \& Ricci Lucchi F., 2001 - The Mediterranean Messinian salinity crisis: an Apennine foredeep perspective. Sedimentary Geology, 140: 201214. https://doi.org/10.1016/S0037-0738(00)00183-4 Rowe P.J., Mason J.E., Andrews J.E., Marca A.D., Thomas L., van Calsteren P., Jex C.N., Vonhof H.B. \& Al-Omari S., 2012 - Speleothem isotopic evidence of winter rainfall variability in northeast Turkey between 77 and $6 \mathrm{ka}$. Quaternary Science Reviews, 45: 60-72. https://doi.org/10.1016/j.quascirev.2012.04.013 
Sauro F., Piccini L., Menichetti M., Artoni A. \& Migliorini E., 2012 - Lithological and structural guidance on speleogenesis in Spluga della Preta Cave, Lessini Mountains (Veneto-Italy). Geografia Fisica e Dinamica Quaternaria, 35: 167-176.

Sauro U., 1996 - Geomorphological aspects of gypsum karst areas with special emphasis on exposed karst. International Journal of Speleology, 25 (3-4): 105-114. https://doi.org/10.5038/1827-806X.25.3.8

Sauro U., 2003a - Aspetti evolutivi del paesaggio carsico nei gessi in Italia. Memorie dell'Istituto Italiano di Speleologia, II (14): 41-45.

Sauro U., 2003b - Dolines and sinkholes: aspects of evolution and problems of classification. Acta Carsologica, 32 (2): 41-52.

Scarabelli G., 1872 - Notizie sulla caverna del Re Tiberio. Lettera del Senatore G. Scarabelli al Chiarissimo Signor Professore Antonio Stoppani (nella seduta del 25 febraio 1872). Atti della Società Italiana di Scienze Naturali, 14: 3-20.

Scholz D. \& Hoffmann D., 2008 - ${ }^{230}$ Th/U-dating of fossil corals and speleothems. Quaternary Science Journal, 57 (1-2): 52-76. https://doi.org/10.3285/eg.57.1-2.3

Scroxton N., Gagan M.K., Dunbar G.B., Ayliffe L.K., Hantoro W.S., Shen C.-C., Hellstrom J.C., Zhao J.X., Cheng H., Edwards R.L., Sun H. \& Rifai, H., 2016 - Natural attrition and growth frequency variations of stalagmites in southwest Sulawesi over the past 530,000 years. Palaeogeography, Palaeoclimatology, Palaeoecology, 441: 823-833.

https://doi.org/10.1016/j.palaeo.2015.10.030

Simoni A., Ponza A., Picotti V., Berti M. \& Dinelli E., 2013 - Earthflow sediment production and Holocene sediment record in a large Apennine catchment. Geomorphology, 188: $42-53$.

https://doi.org/10.1016/j.geomorph.2012.12.006

Sivelli M., 2003 - La speleologia nei gessi d'Italia: un percorso storico. Memorie dell'Istituto Italiano di Speleologia, 2 (14): $27-40$

Sniderman J.M., Woodhead J.D., Hellstrom J., Jordan G.J., Drysdale R.N., Tyler J.J. \& Porch N., 2016 - Pliocene reversal of late Neogene aridification. Proceedings of the National Academy of Sciences, 113 (8): 1999-2004.

https://doi.org/10.1073/pnas.1520188113

Spallanzani L., 1762 - Lettere due dell'abbate Spallanzani al sig. cavalier Vallisneri. Nuova raccolta d'opuscoli scientifici e filologici (Letters two of abbot Spallanzani to sir knight Vallisneri: New collection of scientific and phylologic works). Simone Occhi, Venezia.

Spötl C. \& Mattey D., 2012 - Scientific drilling of speleothems-a technical note. International Journal of Speleology, 41 (1): 29-34.

https://doi.org/10.5038/1827-806X.41.1.4

Stampfli G.M., Mosar J., Fabre P., Pillevuit A. \& Vannay J.-C., 2001 - Permo-Mesozoic evolution of the western Tethys realm: the Neo-Tethys East Mediterranean Basin connection. Mémoires Du Museum National d'Histoire Naturelle, 186: 51-108.

Stefanini G., 1907 - Fenomeni carsici nei gessi della Val d'Era. Rivista Geografica Italiana, 14 (10): 3-15.

Tassi M., 2016 - Tre voragini lungo il corso del Secchia: allarme tra bagnanti ed escursionisti. Il Resto del Carlino 12/072016, Cronaca di Reggio Emilia, 24.

Tedeschi L., D’Angeli I.M., Vigna B., Dalmonte C. \& De Waele J., 2015 - Comportamento idrogeologico di alcune risorgenti carsiche nei gessi dell'Emilia-Romagna. In: De Nitto L., Maurano F. \& Parise M. (Eds), Atti del XXII Congresso Nazionale di Speleologia, Pertosa-Auletta (SA), 30/05-02/06/2015. Memorie Istituto Italiano di Speleologia, 2 (29): 399-404.
Testa G. \& Lugli S., 2000 - Gypsum-anhydrite transformations in Messinian evaporites of central Tuscany (Italy). Sedimentary Geology, 130: 249-268. https://doi.org/10.1016/S0037-0738(99)00118-9

Thunell R., Williams D., Tappa E., Rio D. \& Raffi I., 1990 - Pliocene-Pleistocene stable isotope record for ocean drilling program site 653, Tirrhenian Basin: implications for the palaeoenvironmental history of the Mediterranean Sea. Proc. ODP, Sci. Results: 387-399.

Trevisan L. \& Di Napoli E., 1937 - Tirreniano, Siciliano e Calabriano nella Sicilia sud-occidentale. Note di stratigrafia, Paleontologia e Morfologia. Giornale di Scienze Naturali e Economiche, 39 (8): 1-38.

Tzedakis P.C., Raynaud D., McManus J.F., Berger A., Brovkin V. \& Kiefer T., 2009 - Interglacial diversity. Nature Geoscience, 2 (11): 751-755.

https://doi.org/10.1038/ngeo660

Vai G.B. \& Martini I.P., 2001 - Anatomy of an orogen: The Apennines and adjacent Mediterranean. Dordrecht, Netherlands, Kluwer Academic Publishers, 631 p. https://doi.org/10.1007/978-94-015-9829-3

Vaks A., Bar-Matthews M., Ayalon A., Schilman B., Gilmour M., Hawkesworth C.J., Frumkin A., Kaufman A. \& Matthews A., 2003 - Paleoclimate reconstruction based on the timing of speleothem growth and oxygen and carbon isotope composition in a cave located in the rain shadow in Israel. Quaternary Research, 59 (2): 182-193. https://doi.org/10.1016/S0033-5894(03)00013-9

Vallisneri A., 1715 - Lezione accademica intorno all'origine delle fontane (Academic lecture on the origin of springs). Gabriello Ertz, Venezia.

Vattano M., 2004 - Geomorphological aspects of Monte Conca Karst system (Caltanissetta, Sicily). Memorie dell'Istituto Italiano di Speleologia, 2 (16): 103-114.

Vattano M., 2008 - Geomorphological evolution of evaporite karst areas in south-central Sicily by relationship analysis between hypogean karst landforms and surface landforms. Unpublished Ph.D. thesis, University of Palermo, 250 p.

Vattano M., Interlandi M.M., Buscaglia G \& Madonia G., 2015 - Recenti indagini sul sistema carsico di Sant'Angelo Muxaro (Sicilia centrale). In: De Nitto L., Maurano F. \& Parise M. (Eds.), Atti del XXII Congresso Nazionale di Speleologia, Pertosa-Auletta (SA), 30/0502/06/2015. Memorie Istituto Italiano di Speleologia, 2 (29): 265-270.

Venturini C., Delzotto S., Pondrelli M., Fontana C., Pondrelli M., Longo Salvador G., Carulli G.B. \& Pisa G., $2010-F^{\circ} .031$ Ampezzo (Carta geologica d'Italia alla scala 1:50.000). ISPRA - Servizio Geologico Nazionale.

Vigna B., Fioraso G., De Waele J. \& Banzato C., 2010a - Evolution of karst in Messinian gypsum (Monferrato, Northern Italy). Geodinamica Acta, 23 (1-3): 29-40. https://doi.org/10.3166/ga.23.29-40

Vigna B., Fiorucci A., Banzato C., Forti P. \& De Waele J., $2010 \mathrm{~b}$ - Hypogene gypsum karst and sinkhole formation at Moncalvo (Asti, Italy). Zeitschrift Fur Geomorfologie, 54 (2): 285-306.

https://doi.org/10.1127/0372-8854/2010/ 0054S2-0015

Vigna B., D’Angeli I.M. \& De Waele J., 2017 Hydrogeological flow in gypsum karst areas: some examples from northern Italy and main circulation models. International Journal of Speleology, 46 (2): in this volume.

Volta G.S., 1786 - Osservazioni mineralogiche intorno alle colline di San Colombano dell'Oltrpo' di Pavia. Opuscoli scelti sulle Scienze e sulle Arti, G. Marelli, Milano, 11: 337-351. 
Wainer K., Genty D., Blamart D., Daëron M., BarMatthews M., Vonhof H., Dublyansky Y., PonsBranchu E., Thomas L., van Calsteren P., Quinif Y. \& Caillon N., 2011 - Speleothem record of the last 180 $k a$ in Villars cave (SW France): Investigation of a large $\delta^{18} \mathrm{O}$ shift between MIS6 and MIS5. Quaternary Science Reviews, 30 (1-2): 130-146.

https://doi.org/10.1016/j.quascirev.2010.07.004

Wainer K., Genty D., Blamart D., Bar-Matthews, M., Quinif Y. \& Plagnes V., 2013 - Millennial climatic instability during penultimate glacial period recorded in a south-western France speleothem. Palaeogeography, Palaeoclimatology, Palaeoecology, 376: 122-131. https://doi.org/10.1016/j.palaeo.2013.02.026

Zaccagna D., 1932 - Il fenomeno carsico di Sassalbo nell'Appennino Fivizzanese. Memorie Accademia Lunigianense di Scienze, 13 (1): 48-53.

Zanchetta, G., Drysdale, R.N., Hellstrom, J.C., Fallick, A.E., Isola, I., Gagan, M.K. \& Pareschi, M.T., 2007,
Enhanced rainfall in the Western Mediterranean during deposition of sapropel S1: stalagmite evidence from Corchia cave (Central Italy). Quaternary Science Reviews, 26 (3-4): 279-286.

https://doi.org/10.1016/j.quascirev.2006.12.003

Ziegler M., Tuenter E. \& Lourens L.J., 2010 - The precession phase of the boreal summer monsoon as viewed from the eastern Mediterranean (ODP Site 968). Quaternary Science Reviews, 29 (11-12): 1481-1490. https://doi.org/10.1016/j.quascirev.2010.03.011

Zini L., Calligaris C., Devoto S., Zavagno E., Forte E., Petronio L., Boccali C. \& Cucchi F., 2015a - Fenomeni di sprofondamento nella piana di Enemonzo (UD). Memorie Descrittive Carta Geologica d'Italia, 119: 101-110.

Zini L., Calligaris C., Forte E. Petronio L., Zavagno E., Boccali C. \& Cucchi F., 2015b - A multidisciplinary approach in sinkhole analysis: the Quinis village case study (NE-Italy). Engineering Geology, 197: 132-144. https://doi.org/10.1016/j.enggeo.2015.07.004 